University of South Florida

DIGITAL COMMONS

@ UNIVERSITY OF SOUTH FLORIDA
Digital Commons @ University of

South Florida

3-1-2002

\title{
Synthesis of Securement Device Options and Strategies
}

CUTR

Follow this and additional works at: https://digitalcommons.usf.edu/cutr_nctr

\section{Scholar Commons Citation}

CUTR, "Synthesis of Securement Device Options and Strategies" (2002). Research Reports. 198.

https://digitalcommons.usf.edu/cutr_nctr/198

This Technical Report is brought to you for free and open access by the National Center for Transit Research (NCTR) Archive (2000-2020) at Digital Commons @ University of South Florida. It has been accepted for inclusion in Research Reports by an authorized administrator of Digital Commons @ University of South Florida. For more information, please contact digitalcommons@usf.edu. 


\section{Synthesis of Securement Device Options and Strategies}

Final Report

March 2002

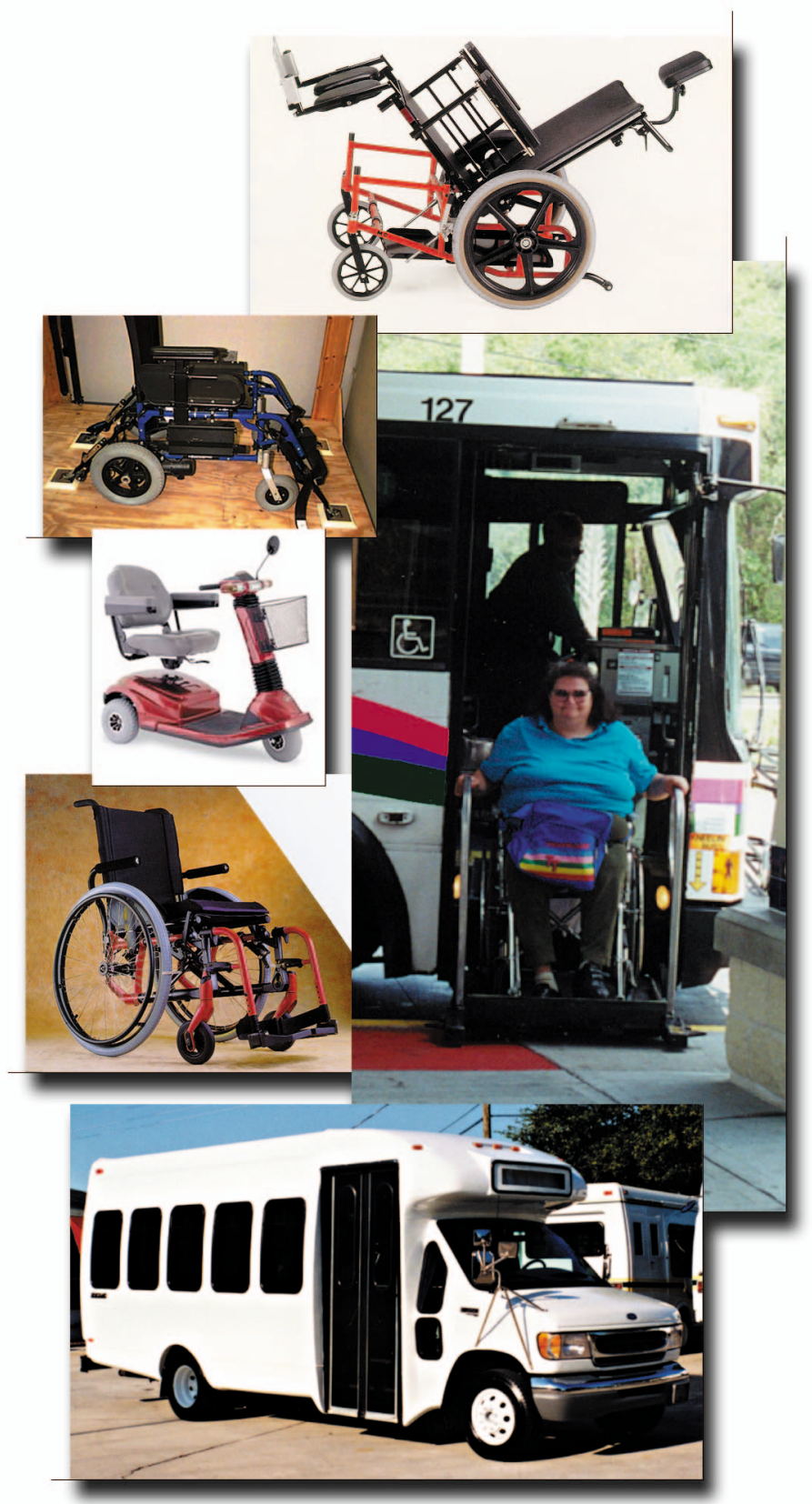


TECHNICAL REPORT STANDARD TITLE PAGE

\begin{tabular}{|c|c|c|}
\hline $\begin{array}{l}\text { 1. Report No. } \\
416-07\end{array}$ & 2. Government Accession No. & 3. Recipient's Catalog No. \\
\hline \multirow{2}{*}{\multicolumn{2}{|c|}{$\begin{array}{l}\text { 4. Title and Subtitle } \\
\text { Synthesis of Securement Device Options and Strategies }\end{array}$}} & $\begin{array}{l}\text { 5. Report Date } \\
\text { March } 2002\end{array}$ \\
\hline & & 6. Performing Organization Code \\
\hline \multicolumn{2}{|c|}{$\begin{array}{l}\text { 7. Author(s) } \\
\text { Hardin, Jennifer, Foreman, Chandra, and Callejas, Linda }\end{array}$} & 8. Performing Organization Report No. \\
\hline \multirow{2}{*}{\multicolumn{2}{|c|}{$\begin{array}{l}\text { 9. Performing Organization Name and Address } \\
\text { National Center For Transit Research (NCTR) } \\
\text { University of South Florida CUT } 100 \\
4202 \text { East Fowler Avenue, Tampa, FL } 33620\end{array}$}} & 10. Work Unit No. \\
\hline & & $\begin{array}{l}\text { 11. Contract or Grant No. } \\
\text { DTRS98-G-0032 }\end{array}$ \\
\hline \multirow[t]{2}{*}{$\begin{array}{l}\text { 12. Sponsoring Agency Name and Address } \\
\text { Office of Research and Special Programs } \\
\text { U.S. Department of Transportation } \\
\text { Washington, DC } 20590\end{array}$} & $\begin{array}{l}\text { Florida DOT } \\
605 \text { Suwannee } \\
\text { Tallahassee, Florida } 32399\end{array}$ & 13. Type of Report and Period Covered \\
\hline & & 14. Sponsoring Agency Code \\
\hline
\end{tabular}

15. Supplementary Notes

Supported by a Grant from the USDOT Research and Special Programs Administration, and the Florida Department of Transportation

16. Abstract

The Americans with Disabilities Act of 1990 (ADA) requires that public transit vehicles be equipped with securement location(s) and device(s) that are able to secure "common wheelchairs," as defined in the ADA regulations. The definition and size specifications related to a "common wheelchair" cover many types of mobility devices, from the traditional wheelchair to three- and four-wheeled motorized "scooters." However, many vehicle operators do not have experience securing non-traditional mobility devices and some very popular types of mobility devices, such as motorized scooters, are extremely difficult to secure using ADA-compliant securement equipment. This report outlines the scope and magnitude of the securement issues facing transit agencies and paratransit providers in the United States by presenting the results of a securement device options and strategies survey that was distributed to transit and paratransit providers throughout Florida and the United States. The results of the survey provide insight into how transit and paratransit providers are dealing with securement issues and the strategies adopted to overcome challenges presented by the securement of mobility aid devices on public transportation vehicles. In addition, an inventory of securement device equipment available in the United States is provided with detailed information about equipment specifications, costs, compatibility with mobility devices, and the types of training offered by securement device manufacturers and vendors. Finally, recommendations are offered to assist in the resolution of the existing disjuncture related to ADA wheelchair securement requirements and difficulties encountered in the securement of common and non-common wheelchairs on public transportation vehicles, which include seeking FTA clarification of inconsistent securement definitions and policies and establishing mandatory standards for mobility devices that will be used as seats on moving public transportation vehicles.

17. Key Words

Public transit, paratransit, wheelchair securement, safety, mobility devices, ADA
18. Distribution Statement

Available to the public through the National Technical Information Service (NTIS), 5285 Port Royal Road, Springfield, VA 22161, (703) 487-4650, and through the NCTR web site at http://www.nctr.usf.edu/
19. Security Classif. (of this report) Unclassified
20. Security Classif. (of this page) Unclassified
21. No. of pages
74 


\section{SYNTHESIS OF SeCUREMENT DeVICE OPTI ONS \& STRATEGI ES}

Final Report 


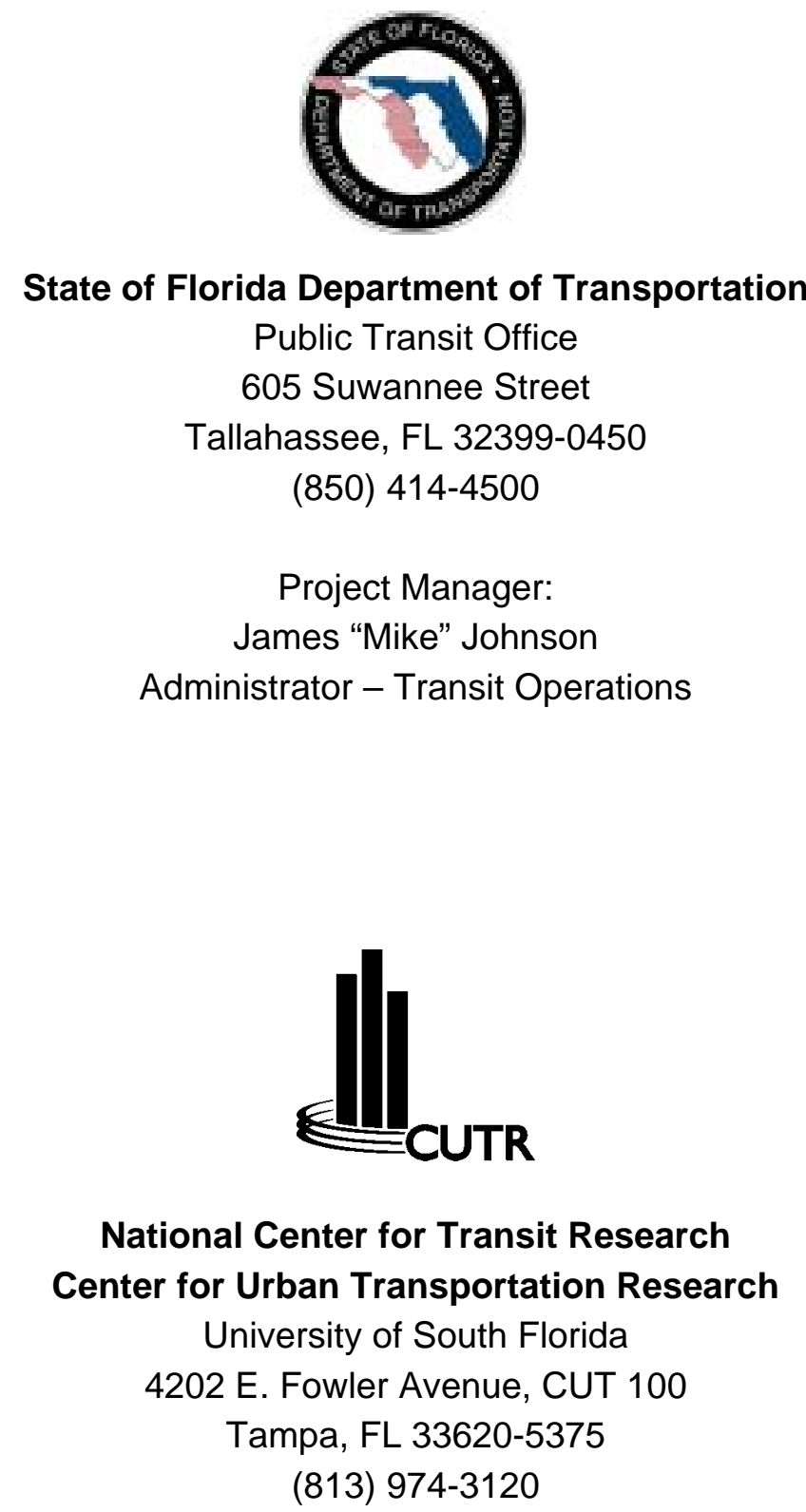

Project Director: Dennis Hinebaugh, Transit Program Director

Project Manager: Jennifer A. Hardin, Research Associate

Project Staff: $\quad$ Chandra C. Foreman, Research Associate

Linda Callejas, Research Assistant

The opinions, findings and conclusions expressed in this publication are those of the authors and not necessarily those of the U.S. Department of Transportation or the State of Florida Department of Transportation. 


\section{Table of Contents}

Section One: Securement Device Options \& Strategies Survey ...........................................

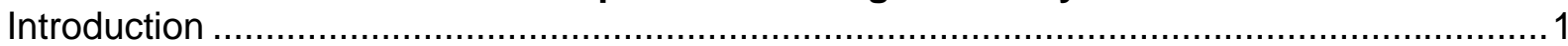

Mobility Aid Device Securement Issues .....................................................................

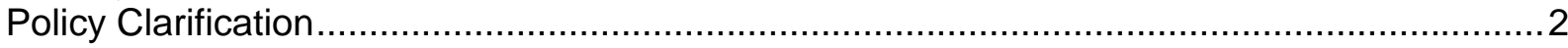

Passenger Issues.................................................................................................

Agency and Operator Issues..................................................................................

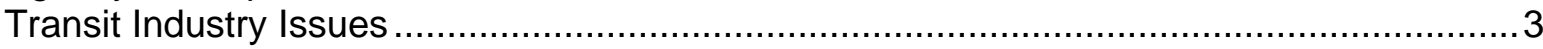

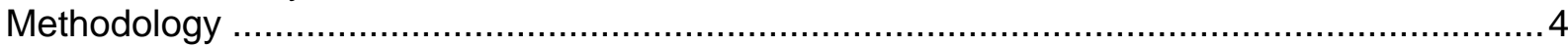

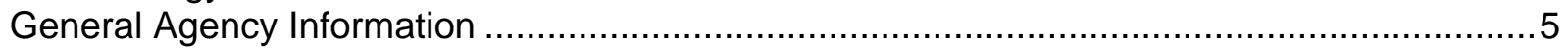

Transportation Services Provided ………………

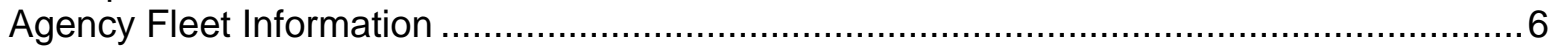

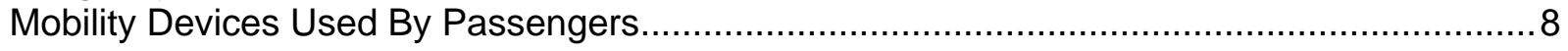

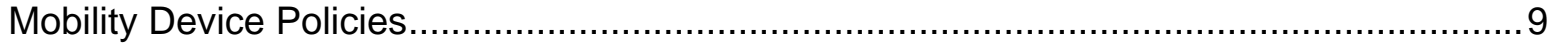

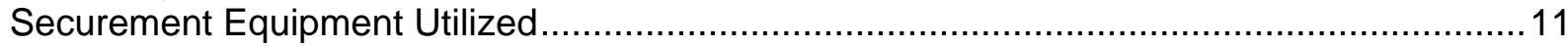

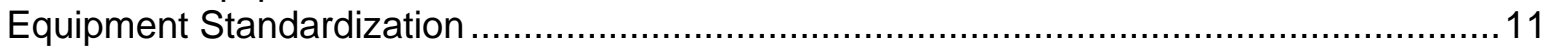

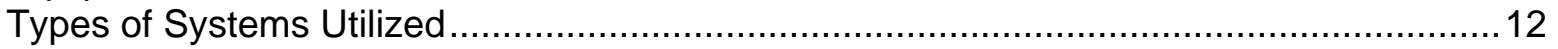

Advantages and Disadvantages of Devices Most Often Used......................................... 14

Time Required to Secure Mobility Aid Devices ...........................................................17

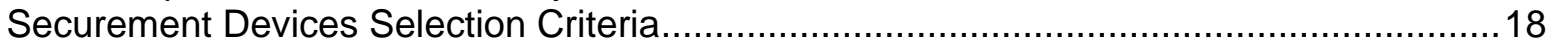

Selection Criteria with Greatest Impact............................................................... 19

Mobility Device Accommodation Challenges and Strategies .............................................2

Mobility Devices That Do Not Meet the Definition of "Common Wheelchair" ........................21

Ability to Secure "Non-Common Wheelchairs"..............................................................22

Transporting Passengers with Non-Common Mobility Devices ........................................24

Driver Responses to Non-common Wheelchairs ………….........................................25

Strategies to Accommodate "Non-Common Wheelchairs" ..............................................2. 26

Difficulties with the Accommodation of "Common Wheelchairs"......................................28

Strategies to Accommodate Difficult to Secure "Common Wheelchairs" ............................29

Securement-related Trip Denials ................................................................................ 31

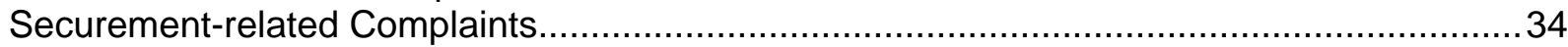

Passenger Complaints ........................................................................................

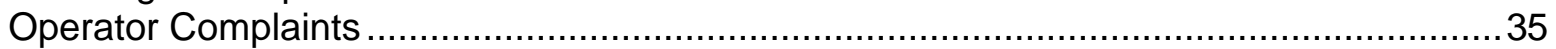

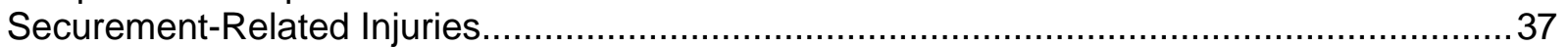

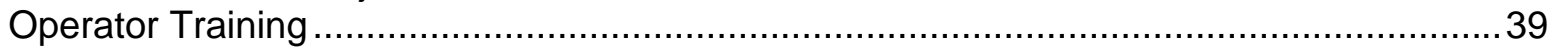

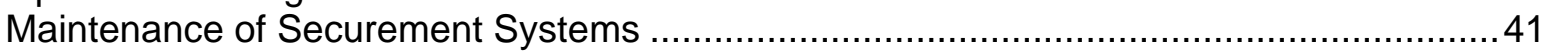

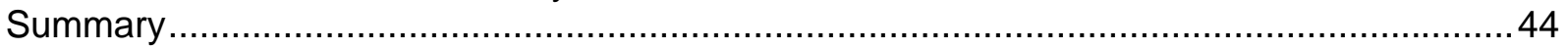

Section Two: Inventory of Wheelchair Securement Devices.............................................47

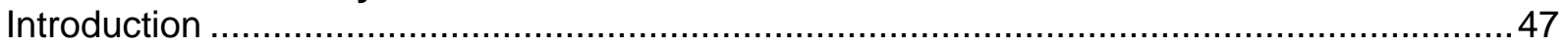

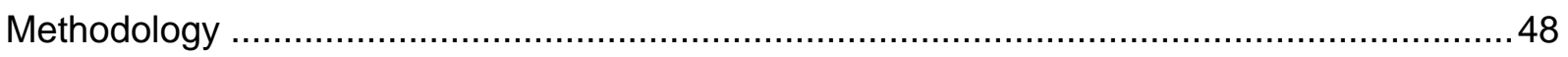

Vendors and Manufacturers.............................................................................. 49

Wheelchair Securement Device Inventory General Findings ............................................49

Wheelchair Securement Device Inventory Matrix: Included Elements..................................51

Section Three: Discussion ..........................................................................................69

Recommendation 1:...Seek FTA Clarification related to Inconsistent Securement Definitions \&

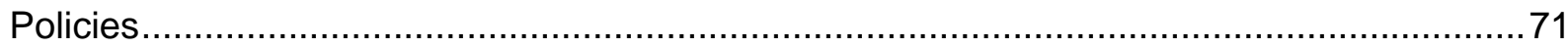

Recommendation 2:. Make ANSI/RESNA Standard WC/Volume 1 - Section 19 Wheelchairs -

Wheelchairs Used as Seats in Motor Vehicles Mandatory for Public Transportation ..............72 


\section{Section One: Securement Device Options \& Strategies Survey}

\section{Introduction}

The Americans with Disabilities Act of 1990 (ADA) transportation requirements ushered in a new era of public transportation accessibility for persons with disabilities. This groundbreaking civil rights initiative has given persons with disabilities the same mobility opportunities available to others by requiring accessible fixed-route transportation, as well as complementary paratransit services for individuals who are unable to use accessible fixed-route services. Among other accessibility mandates, the ADA transportation requirements provide specifications for ensuring that mobility aid devices (e.g. wheelchairs) are properly and safely secured in public transportation vehicles. The transportation regulations specify that at least two mobility aid securement locations and devices be provided on vehicles over 22 feet long, and one device and location in smaller vehicles. In addition to providing guidance on the placement of securement locations, the regulations also define load requirements of the securement equipment. Finally, the securement devices used in public transportation vehicles must secure "common wheelchairs." The ADA defines a "common wheelchair" as a mobility device that does not exceed 30 inches in width and 48 inches in length and weighs no more than 600 pounds when occupied. Although the ADA establishes requirements for the securement of common wheelchairs, many transit agencies still experience a variety of challenges related to the safe and effective securement of certain types of mobility aid devices.

\section{Mobility Aid Device Securement I ssues}

In the decade following the passage of the ADA, agencies and passengers have worked diligently to achieve greater understanding in order to facilitate full compliance with the legislative requirements of ADA. This has involved clarification of FTA policy and requirements, as well as the identification of salient issues. In terms of securement, these issues may be understood from the perspective of passengers, agencies, operators, and the transit industry. Each of these areas will be discussed in the following sections. 


\section{Policy Clarification}

The Federal Transit Administration's Office of Civil Rights (TCR) monitors the implementation of and compliance with the ADA transportation regulations by investigating complaints and conducting reviews. Transit agencies and providers look to TCR for interpretive guidance on issues related to the ADA, including current policy related to the securement of mobility aid devices. Unfortunately, from the perspective of transit agencies and passengers, the guidance provided by the TCR has not always been clear and this has resulted in inconsistent interpretation of the transportation rules and regulations.

The inquiries and complaints received by the TCR indicate that public transportation providers and passengers do not have a clear understanding of ADA mandates. This lack of understanding includes issues related to wheelchair securement. While the focus of individual inquiries and complaints vary, the most common securement themes relate to trip denial, improper securement, and whether or not passengers must be secured at all. Securement issues related to trip denial or refusal include the use of mobility aids that do not meet the ADA definition of "common wheelchair" (e.g., oversized wheelchairs or excessive weight), the lack of securement devices installed on vehicles, the inability to secure certain types of mobility devices, and/or malfunctioning devices. In another issue, passengers may not feel that they are being secured properly due to lack of operator training or lack of confidence in the securement equipment being used. Agencies also have concerns about securing mobility aid devices that meet the definition of a common wheelchair, but lack traditional securement points. Finally, there has been confusion over FTA policy regarding the securement requirements. TCR has recently attempted to address this issue by providing formal interpretation that allows fixed-route operators and paratransit providers the discretion to make wheelchair securement on buses either mandatory or optional (FTA Letter of Interpretation, October 20, 2000). According to TCR interpretive guidance, if a transit provider requires that a passenger using a mobility aid device be secured, it must state so in a formal, written policy. Otherwise, a passenger using a mobility aid device may elect to not have his or her wheelchair secured. 


\section{Passenger Issues}

The issues introduced in the above section also highlight many of the issues that passengers have with securement policies and procedures. Particularly, some passengers who use mobility devices are frustrated that transit agencies may require that their devices be secured when using public transit. They resist the securement of their mobility devices because this is not required of other passengers. An additional concern expressed by passengers who use mobility devices relates to potential damage to mobility device caused by improper securement. Related passenger concerns include inadequate operator training and the availability of securement options that allow passengers to secure their own devices without the assistance of operators.

\section{Agency and Operator Issues}

Transit providers and operators also have identified issues with securement policy and procedures. Of primary concern to agencies are securement issues related to safety and liability. Many of these concerns have been alluded to earlier in this section, specifically in relation to requiring (or not) the securement of mobility devices on transit vehicles and the occurrence of incidents and/or accidents resulting from improper securement or malfunctioning securement equipment. Transit agencies are also faced with the challenge of identifying securement systems that effectively secure a wide variety of mobility devices in a reasonable amount of time. This has been particularly prominent in discussions related to the securement of motorized three- and four-wheeled scooters. Transit agencies and vehicle operators alike have raised the issue of the amount of time required to secure mobility devices. While the time required to secure common wheelchairs on transit vehicles is a factor of both the types of mobility devices and securement equipment in use, it is also affected by the quality and extent of training provided to vehicle operators. As stated previously, some passengers would prefer that their mobility device not be secured at all and/or dislike operator-assisted securement. Such resistance may make it difficult for operators to follow agency securement policies.

\section{Transit Industry Issues}

In recent years, the transit industry, as a whole, has begun to address the various issues that have been raised with regard to the securement of mobility devices on transit vehicles. In 
particular, the industry has concerns about the wide variety of mobility aid devices used by passengers. This presents a dilemma for the transit industry in terms of finding or developing effective and feasible means of safely securing each type of mobility device. To date, the efforts to address these concerns have taken a two-pronged approach: first, developing universal standards for securement devices and second, developing standards for the mobility aid devices used as seats in motor vehicles. Many in the transit industry feel that until these issues are resolved, the safe securement of mobility aid devices on transit vehicles will continue to be a challenge.

In an effort to further outline the scope and magnitude of the securement issues facing transit agencies and paratransit providers in the United States, the Center for Urban Transportation Research (CUTR) developed and conducted a securement device options and strategies survey. The results of this survey provide insight into how transit and paratransit providers are dealing with securement issues and the strategies adopted to overcome challenges presented by the securement of mobility aid devices on transit vehicles. The survey methodology and results are presented in the following sections.

\section{Methodology}

In J une 2001, a Securement Device Options and Strategies Survey was distributed to 49 Florida Community Transportation Coordinators (CTCs), 129 paratransit providers under contract to Florida's CTCs, and 22 Florida transit properties. In addition, 70 non-Florida transit properties also received the survey. A total of 270 agencies were surveyed and 95 responses were received ( 54 received from Florida agencies and 41 received from non-Florida agencies). This represents a 35 percent response rate.

The following sections present the survey results. A copy of the survey is included in Appendix A. The analysis is grouped according to the following topics: General Agency Information, Securement Equipment, Mobility Device Accommodation Challenges and Strategies, Securement-related Complaints, Operator Training, and Maintenance of Securement Equipment. 


\section{General Agency I nformation}

The initial section of the survey attempted to identify general characteristics about the agencies being surveyed. Survey questions related to general agency characteristics included information about the types of transportation services provided by agency, the number of fulltime and part-time vehicle operators, the number of vehicles in the agency's fleet, the number of vehicles accessible to people with disabilities, the types of mobility devices used by their passengers, and agency policies regarding the securement of mobility devices. The general characteristics of all responding agencies are described in the following sections.

\section{Transportation Services Provided}

Respondents were asked to indicate all of the types of transportation services provided by their agency. As illustrated in Table 1, most of the respondents of the survey (63 percent) indicated that they provide fixed schedule, fixed route service. Half of the sampled respondents (50 percent) indicated that they provide door-to-door service. Further, 47 percent of respondents said they offer curb-to-curb service. Only 19 percent said that they provide some other, not listed service. The responses provided in the "other" category include paratransit, rail (electric street cars), commuter rail, door-to-door stretcher service, Department of Human Services transportation, skyway and trolley service, vanpool/rideshare, disadvantaged transport, job transportation, before and after hours community service, hospital discharges, and fixed-route with deviation.

Table 1

Q.1 -- What types of transportation services does your agency provide?

\begin{tabular}{|l|r|r|}
\hline Types of transportation services: & Frequency & Percent \\
\hline Fixed schedule, fixed route & 60 & $63 \%$ \\
Curb-to-curb service & 45 & $47 \%$ \\
Door-to-door service & 48 & $50 \%$ \\
Other & 18 & $19 \%$ \\
\hline
\end{tabular}

Note: Respondents may provide more than one of these services.

Table 2 provides further analysis of the types of transportation services offered by survey respondents by indicating the distribution of services provided by each agency. Only fixed schedule, fixed-route, curb-to-curb, and door-to-door services are considered, as the responses provided in the "other" category are too varied for analysis. Three percent of agencies marked 
"other" as the only type of service provided. As illustrated in Table 2 and Figure 1, 21 percent of respondents said they provide fixed schedule, fixed route, as well as curb-to-curb services. Nineteen percent of respondents indicated that they provide door-to-door service only. Sixteen percent indicated that they only provide fixed schedule, fixed route service. Fifteen percent of respondents indicated that they provide fixed schedule, fixed route service, as well as door-todoor services. An additional 12 percent reported that they provide all three services, and 9 percent of respondents indicated that they provide curb-to-curb service only.

Table 2

Distribution of Services Provided

\begin{tabular}{|l|r|r|}
\hline Types of services provided: & Frequency & Percent \\
\hline Fixed schedule, fixed route only & 15 & $16 \%$ \\
Curb-to-curb service only & 9 & $9 \%$ \\
Door-to-door service only & 18 & $19 \%$ \\
Fixed schedule, fixed route, and curb-to-curb service & 20 & $21 \%$ \\
Fixed schedule and door-to-door service & 14 & $15 \%$ \\
Curb-to-curb and door-to-door services & 5 & $5 \%$ \\
All three services & 11 & $12 \%$ \\
Only provide "other" service & 3 & $3 \%$ \\
Total & 95 & $100 \%$ \\
\hline
\end{tabular}

Figure 1

Distribution of Services Provided

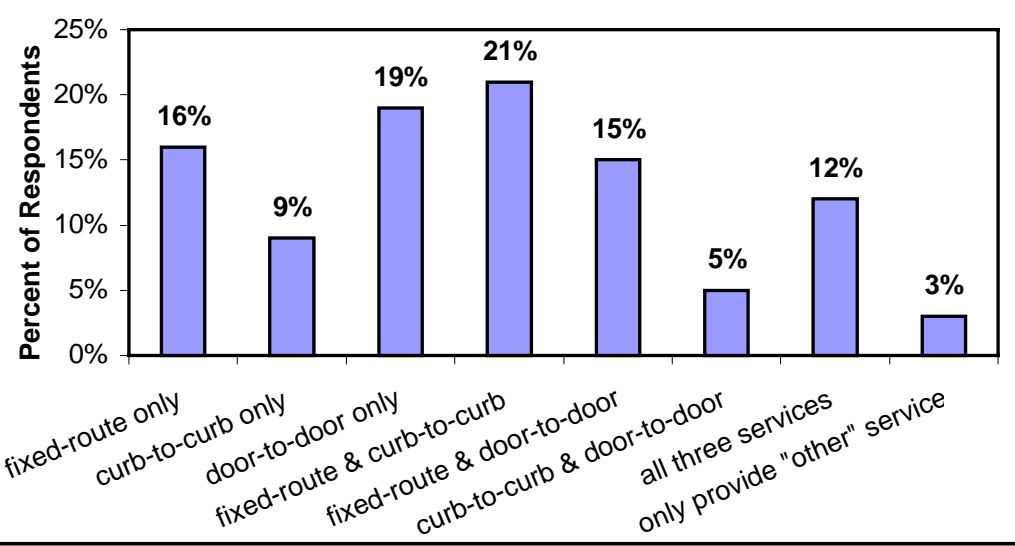

Agency Fleet Information

The agencies that responded to the securement survey represented a wide range of vehicle fleet sizes. As shown in Table 3, agencies reported operating between zero and 2270 total 
vehicles. Because of the wide range in response distribution, categories of pooled responses were created in order to facilitate analysis. Four percent or four respondents did not provide an answer to this question; however, nearly half of the respondents (43 of 95) indicated that their agency operates between zero and 50 total vehicles. Thirty-four percent indicated that their agency fleet consists of between 51 and 250 vehicles. Sixteen percent indicated that their agency fleet consists of more than 250 vehicles. The largest number of vehicles reported was 2270.

Table 3

Q.3- How many vehicles do you have in your fleet?

\begin{tabular}{|l|r|r|}
\hline No. of vehicles in fleet & \multicolumn{1}{|c|}{ Frequency } & \multicolumn{1}{|c|}{ Percent } \\
\hline $0-50$ & 43 & $45 \%$ \\
$51-250$ & 32 & $34 \%$ \\
$251-2270$ & 16 & $17 \%$ \\
No response & 4 & $4 \%$ \\
Total & 95 & $100 \%$ \\
\hline
\end{tabular}

Table 4 and Figure 2 provide information about the percentage of agency vehicles accessible to persons with disabilities. Eighty-four of 95 of the survey respondents provided information on this topic. It is expected that fixed-route transit providers would be in full compliance with the ADA requirement for total fleet accessibility. In fact, over half of the responding agencies reported that their entire vehicle fleet (100 percent) is accessible to persons with disabilities. On the other end of the spectrum, six of the agencies reported that less than 25 percent of their vehicle fleet is accessible to persons with disabilities. A review of the data indicates that the large majority of agencies without 100 percent vehicle accessibility are paratransit contractors and/or providers. It is important to note that these agencies' vehicle fleets likely include a mix of vehicle types in response to the varied needs of their clients, such as sedans, standard passenger vans, wheelchair accessible vans, and paratransit buses. It is, therefore, understandable that their entire fleet would not be accessible to persons with disabilities.

Table 4

Percentage of Total Agency Fleet Accessible to People with Disabilities

\begin{tabular}{|l|r|r|}
\hline & Frequency & \multicolumn{1}{|c|}{ Percent } \\
\hline $0-25 \%$ & 6 & $7 \%$ \\
$26 \%-50 \%$ & 10 & $12 \%$ \\
$51 \%-75 \%$ & 12 & $14 \%$ \\
$76 \%-99 \%$ & 10 & $12 \%$ \\
$100 \%$ & 46 & $55 \%$ \\
\hline \multicolumn{2}{|c|}{ Note: Only valid responses are shown. }
\end{tabular}




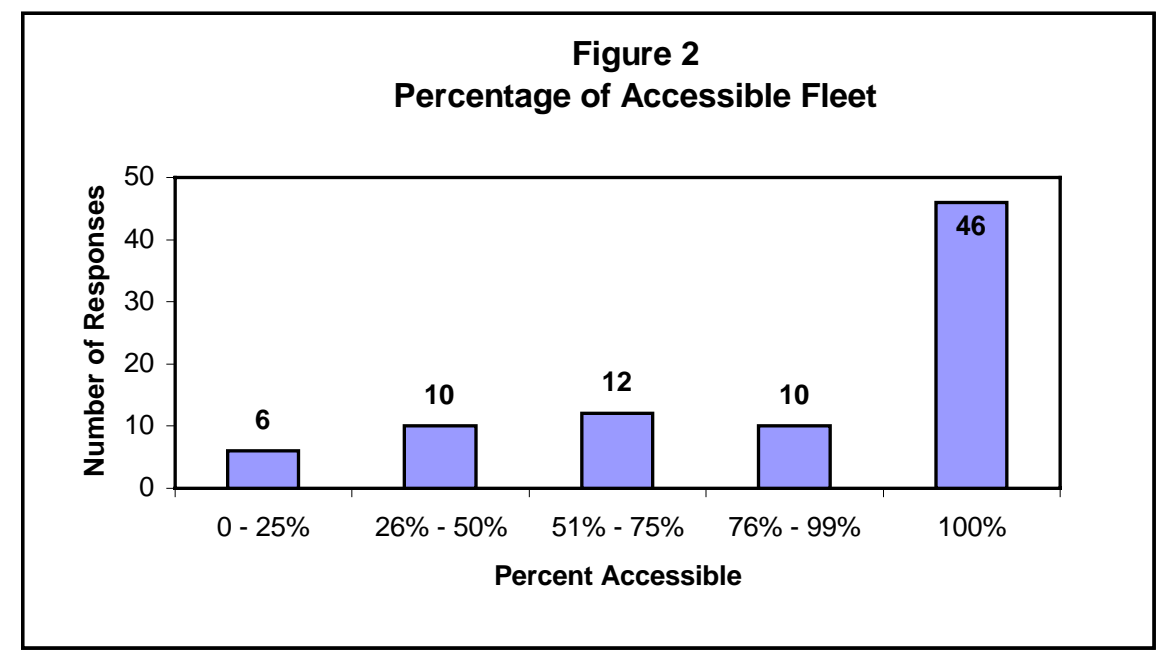

\section{Mobility Devices Used By Passengers}

Information was also gathered from respondents related to the types of mobility aid devices used by passengers. Respondents were also asked to rank mobility aid devices according to the frequency of their use by transportation customers. A list of popular mobility devices was provided from which to make selections. Included in the list were manual wheelchairs, powered wheelchairs, and three- and four-wheel scooters. The participants were also provided space to identify devices not listed. Table 5 shows the distribution of responses with regard to frequency of mobility aid devices used by passengers. As illustrated in Table 5 and Figure 3, over half of respondents (66 percent) indicated that manual wheelchairs were "used most often" by their passengers. Close to one half of respondents (46 percent) indicated that powered wheelchairs were "used very often," while 41 percent indicated that 3-wheel scooters were "used often." Forty-five percent of respondents indicated that 4-wheel scooters were "not used very often" by passengers, while 19 percent said that "other" types of mobility aid devices were "used least often." Eighty-four percent (16 of 19) of those who marked the "other" category in response to this question provided a description of the mobility aid devices used most often by their passengers. Ten percent of these respondents indicated that their passengers also use "Geri-chairs" or stretchers. Six percent listed walkers, canes, or strollers in the "other" category. The remaining respondent listed oversized wheelchair as a response, but did not provide additional description about the device. 
Table 5

Q.5 - Please rank mobility aid devices according to those most often used by your passengers.

\begin{tabular}{|l|r|r|r|r|r|}
\hline $\begin{array}{l}\text { Mobility aid devices } \\
\text { used: }\end{array}$ & \multicolumn{1}{c|}{$\begin{array}{c}\text { used most } \\
\text { often }\end{array}$} & \multicolumn{1}{c|}{$\begin{array}{c}\text { used very } \\
\text { often }\end{array}$} & used often & \multicolumn{1}{c|}{$\begin{array}{c}\text { not used } \\
\text { very often }\end{array}$} & $\begin{array}{c}\text { used least } \\
\text { often }\end{array}$ \\
\hline Manual wheelchair & $66 \%(63)$ & $12 \%(11)$ & $5 \%(5)$ & $8 \%(8)$ & $3 \%(3)$ \\
\hline Powered wheelchair & $24 \%(23)$ & $46 \%(44)$ & $12 \%(12)$ & $3 \%(3)$ & $8 \%(8)$ \\
\hline 3-wheel scooter & $4 \%(4)$ & $13 \%(12)$ & $41 \%(39)$ & $13 \%(12)$ & $16 \%(15)$ \\
\hline 4-wheel scooter & 0 & $5 \%(5)$ & $14 \%(13)$ & $45 \%(43)$ & $18 \%(17)$ \\
\hline Other & $1 \%(1)$ & $2 \%(2)$ & $2 \%(2)$ & $1 \%(1)$ & $19 \%(18)$ \\
\hline
\end{tabular}

Note: Between 6 and 9 missing responses per use category.

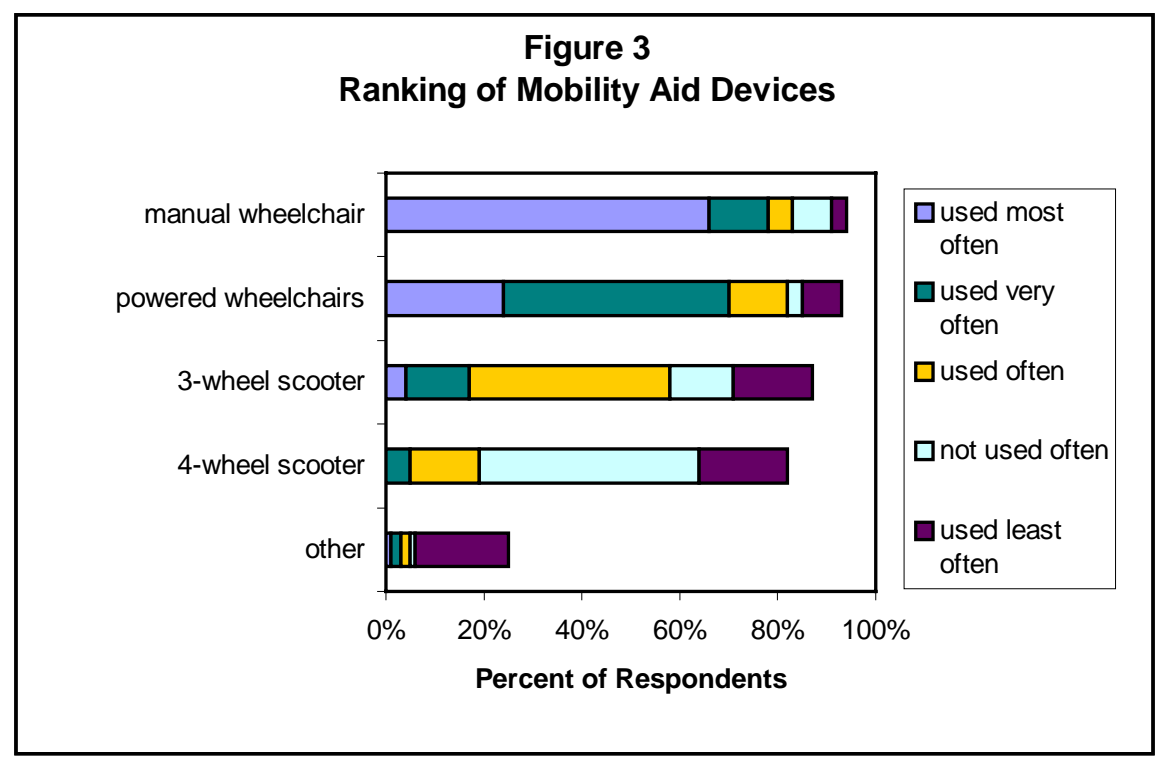

Mobility Device Policies

In an effort to determine how agencies are responding to local options related to requiring securement, respondents were asked to indicate whether or not their agency has a policy that requires the securement of mobility aid devices. Table 6 , below, shows the distribution of responses to this question. The majority of respondents (88 percent) indicated that they have a formal policy requiring the securement of mobility aid devices, while only seven percent indicated that they do not have such a policy. 
Table 6

Q.8 - Does your agency have a policy that requires the securement of mobility aid devices?

\begin{tabular}{|l|r|r|}
\hline & Frequency & \multicolumn{1}{|c|}{ Percent } \\
\hline Yes & 84 & $88 \%$ \\
No & 7 & $7 \%$ \\
Don't know & 1 & $1 \%$ \\
Blank/no answer & 2 & $2 \%$ \\
Not applicable & 1 & $1 \%$ \\
Total & 95 & $100 \%$ \\
\hline
\end{tabular}

Those respondents who indicated that their agency does have a policy that requires the securement of mobility aid devices were asked if this policy is stated in a manual, handbook, or in another printed document. As noted previously in Table 6, 84 of the survey respondents acknowledged having a policy requiring the securement of mobility devices. According to Table 7, ninety percent of those agencies confirmed that the policy is formally documented. Only four percent indicated that the policy is not documented in a printed format. The remaining five respondents either did not know if their agency had a written securement policy $(n=2)$, did not think that the question was applicable to them $(n=2)$, or did not respond to the question $(n=1)$.

Table 7

Q.9 - Is the policy stated in a manual, handbook, or other printed document?

\begin{tabular}{|l|r|r|}
\hline & Frequency & Percent \\
\hline Yes & 76 & $90 \%$ \\
No & 3 & $4 \%$ \\
Don't know & 2 & $2 \%$ \\
Blank/no answer & 1 & $1 \%$ \\
Not applicable & 2 & $2 \%$ \\
Total & 84 & $100 \%$ \\
\hline
\end{tabular}
Note: This question was only asked of those who responded to Question $8 . \quad(N=84)$

Finally, the survey participants were asked to indicate whether their agency's governing body or other entity has securement system requirements that go beyond those included in the Americans with Disabilities Act (ADA) of 1990 (see Table 8). The majority of respondents (74 percent) said that they do not. Only fourteen percent of respondents indicated that their agency does have securement system requirements beyond those included in the ADA. Only two of the 13 survey participants who said that their agency has securement system requirements beyond those established by the ADA responded to the opportunity to elaborate on the additional requirements. The responses provided by these agencies included the requirement that vacant mobility devices must be secured when it's occupant transfers to a 
vehicle seat, and the existence of and agency-sponsored program for the distribution of yellow securement loops to passengers using mobility devices to identify the safest securement points on devices.

Table 8

Q.23 - Does your agency's governing body or other entity have securement system requirements beyond those included in the ADA?

\begin{tabular}{|l|r|r|}
\hline & Frequency & Percent \\
\hline Yes & 13 & $14 \%$ \\
No & 70 & $74 \%$ \\
Blank/no answer & 12 & $13 \%$ \\
Total & 95 & $100 \%$ \\
\hline
\end{tabular}

\section{Securement Equipment Utilized}

The Securement Device Options and Strategies Survey was designed to collect extensive information about the securement equipment presently utilized by transit and paratransit providers. Agencies were asked to provide information regarding existing equipment standardization on vehicles and the types of securement systems used on agency vehicles. In addition, participants were also queried about specific advantages and disadvantages associated with the securement devices used and criteria applied in selecting wheelchair securement equipment for agency vehicles. The responses provided by survey participants are discussed in the sections that follow.

\section{Equipment Standardization}

Respondents were queried about the level of equipment standardization that exists in their vehicle fleet to determine if individual agencies are using a variety of types of securement devices, or if a single type is most prevalent. As Table 9 and Figure 4 indicate, 58 percent reported that securement equipment varies by vehicle. Thirty-seven percent indicated that their agency uses the same type of securement equipment for all vehicles. 
Table 9

Q.17 - Do you have standard securement for all vehicles, or does the equipment vary by vehicle?

\begin{tabular}{|l|r|r|}
\hline & Frequency & Percent \\
\hline Standard securement equipment for all vehicles & 35 & $37 \%$ \\
Securement equipment varies by vehicle & 55 & $58 \%$ \\
Blank /no answer & 5 & $5 \%$ \\
Total & 95 & $100 \%$ \\
\hline
\end{tabular}

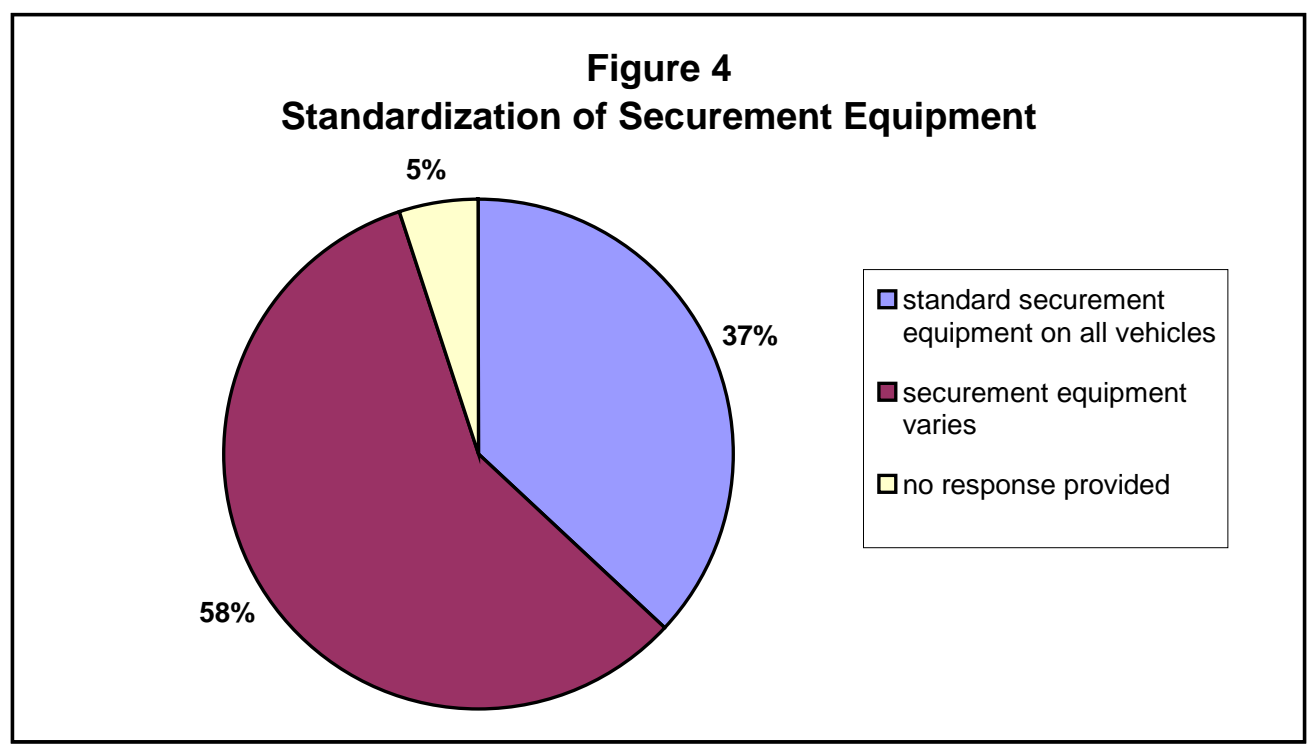

Types of Systems Utilized

Respondents were asked to provide information about the types of securement systems currently utilized by their agency. They were asked to select all applicable responses from a list provided, as shown in Table 10. Table 10 and Figure 5 show the number of times all respondents selected one or more of the listed securement devices. Not surprisingly, a majority of agencies reported use of tie-down/belt systems and wheel-lock securement devices, two of the most commonly installed wheelchair securement options in the United States. Nearly all of the responding agencies (94 percent) indicated that they use tie-down/belt systems. In addition, 42 percent indicated that their agency also relies on wheel-lock devices. 
Table 10

Q.18 - What type of securement system(s) does your agency utilize?

\begin{tabular}{|l|r|r|r|r|}
\hline \multirow{2}{*}{ Securement systems utilized: } & \multicolumn{2}{|c|}{ Selected } & \multicolumn{2}{c|}{ Not selected } \\
\cline { 2 - 4 } & Frequency & Percent & Frequency & \multicolumn{1}{c|}{ Percent } \\
\hline Wheel-lock device & 40 & $42 \%$ & 55 & $58 \%$ \\
Tie-down/belt system & 89 & $94 \%$ & 6 & $6 \%$ \\
Docking/interface system & 5 & $5 \%$ & 90 & $95 \%$ \\
T-bar & 3 & $3 \%$ & 92 & $97 \%$ \\
Fender brackets & 0 & $0 \%$ & 95 & $100 \%$ \\
Other & 3 & $3 \%$ & 92 & $96 \%$ \\
\hline
\end{tabular}

Note: The table above shows whether respondents selected or did not select each of the categories listed in response to the question above. Only valid responses are shown.

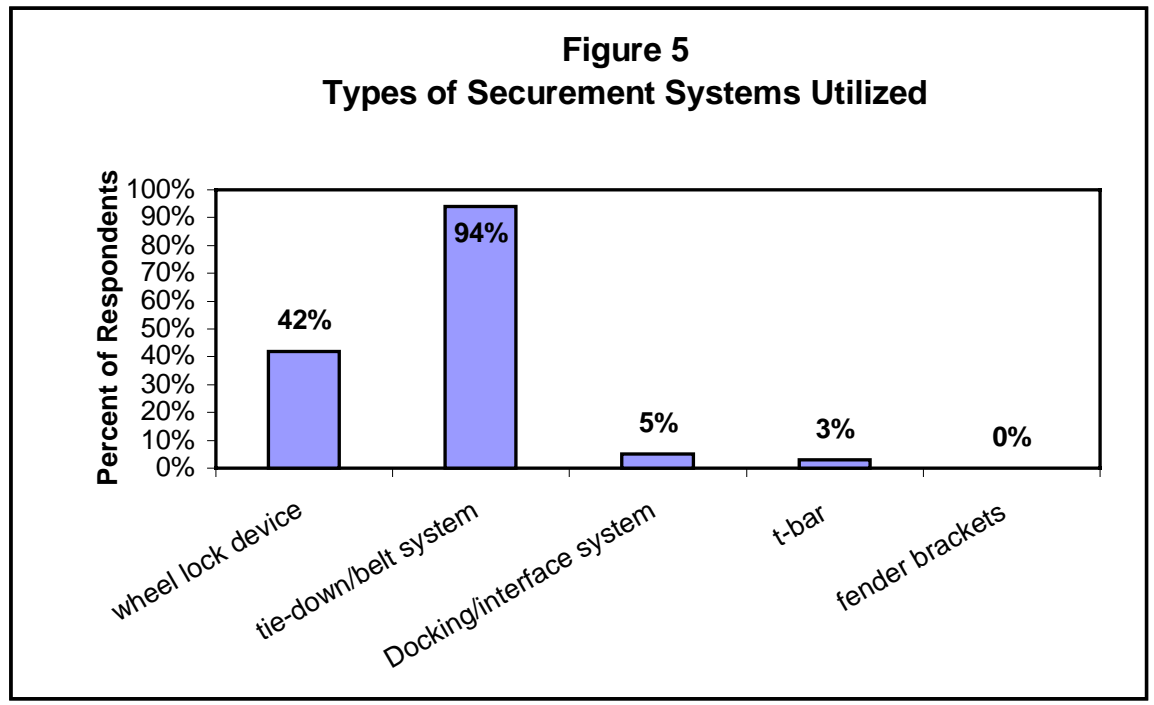

In a related question, respondents were asked to identify the securement system used most often by their agency. Results are shown in Table 11 and Figure 6 . Again, tie-down/belt systems appear to be the most popular type of securement equipment currently in use, with 77 percent of respondents indicating that their agency uses this type of device most often. Five percent indicated that they use the wheel-lock device system most often to secure mobility devices, while two percent said they rely on the docking/interface system most often. Some agencies appear to be achieving safe securement by combining multiple types of securement equipment. For example, four percent of respondents indicated that their agency relies most often on a combination of tie-down belts and wheel-lock devices. One respondent indicated that the agency relies most on a combination of tie-down belts, wheel-lock devices, and a t-bar. 
Table 11

Q.19 - What type of securement device is used most often?

\begin{tabular}{|l|r|r|}
\hline \multirow{2}{*}{ Securement systems utilized: } & \multicolumn{2}{|c|}{ Selected } \\
\cline { 2 - 3 } Wheel-lock device & 5 & \multicolumn{1}{c|}{ Percent } \\
Tie-down/belt system & 73 & $77 \%$ \\
Docking/interface system & 2 & $2 \%$ \\
Tie-down belts and wheel-lock device & 4 & $4 \%$ \\
Tie-down belts, wheel-lock device and t-bar & 1 & $1 \%$ \\
Blank/no answer & 10 & $11 \%$ \\
Total & 95 & $100 \%$ \\
\hline
\end{tabular}

Figure 6

Type of Securement Device Used Most Often
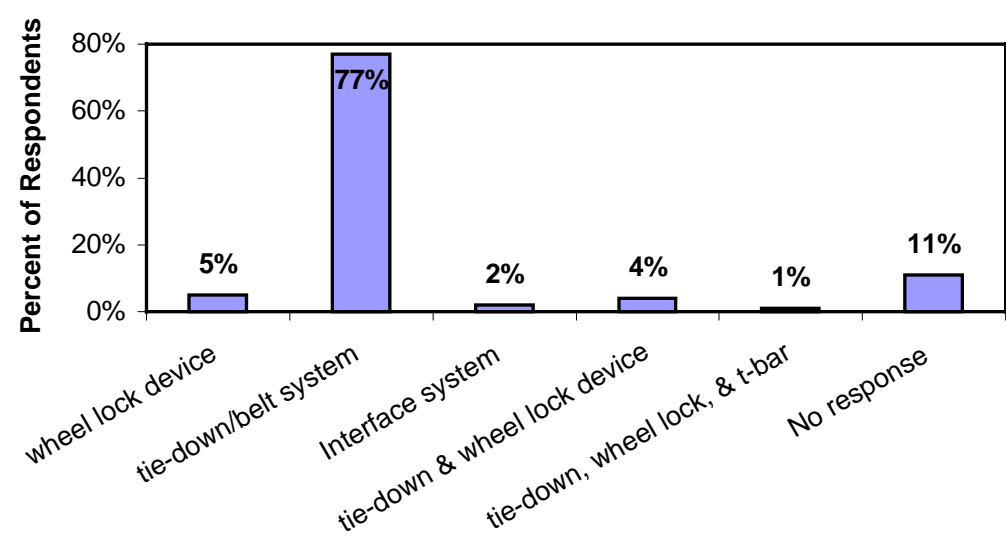

Advantages and Disadvantages of Devices Most Often Used

In an effort to further elucidate the experiences and/or challenges agencies are facing in terms of mobility device securement, respondents were asked to identify the advantages and disadvantages of the securement system most often utilized by their agency. As discussed above, 77 percent of respondents identified the tie-down/belt system as the type of securement device used most often by their agency. Consequently, the majority of responses regarding specific advantages and disadvantages related to securement equipment refer almost exclusively to the tie-down/belt securement system.

The survey question regarding securement system advantages elicited an 85 percent response rate, with 81 of 95 possible responses. In general, respondents identified the greatest advantage (or only advantage) of their particular systems. In all, 31 percent of respondents 
(25 of 81) identified the flexibility of the securement system or the ability to secure a wide variety of mobility aid devices as the main advantage to using the current system installed in agency vehicles. Twenty-eight percent (23 of 81 ) of respondents specifically cited the flexibility associated with tie-down/belt systems as the main advantage. One of the five respondents who reported using wheel-lock devices most often in fleet vehicles also cited the flexibility of the system, as did one of the three respondents who reported using a combination of the tiedown/belt system and wheel-lock devices most often.

Another 31 percent ( 25 of 81 ) of the responses identified safety as the main advantage to using a particular securement device. Responses emphasizing safety included those identifying better or increased securement and/or increased passenger feelings of security or safety. The majority of these responses (24 of 25) were reported with regard to the tie-down/belt securement system. The only respondent in the sample that reported using a combination of the tie-down/belt system, wheel-lock devices, and a t-bar in agency vehicles cited safety as the main advantage of using these systems together.

Eighteen percent (15 of 81 ) of responses cited the securement system's ease of use as a main advantage. Thirteen of these responses related specifically to the use of the tie-down/belt system. One response cited ease of use with regard to the use of wheel-lock devices, and another respondent did so with regard to the combined use of the tie-down/belt system and the wheel-lock device.

Ten percent of respondents ( 8 of 81 ) cited the speed with which mobility devices can be secured with a particular securement system as a main advantage. Four of these responses were given with regard to the use of the tie-down/belt system. Three of these responses were given with regard to the use of wheel-lock devices. The remaining respondent cited speed of securement with regard to the combined use of the tie-down/belt system and a wheel-lock device. Other advantages identified include uniformity of securement and ease for drivers, customer preference and sense of security, reduced damage to mobility devices, reliability, durability, and compliance with ADA requirements. 
Respondents were also asked to identify any disadvantages associated with the securement system utilized by their agency most often. As with the question related to securement system advantages, responses refer almost exclusively to the use of the tie-down/belt system. This question had a similar response rate to the previous one (86 percent or 82 of 95), although respondents were less succinct in identifying disadvantages, often identifying more than one disadvantage. The amount of time required to secure a mobility device was specifically identified by 27 percent of respondents ( 22 of 82 ) as the main disadvantage in using the system currently installed in agency vehicles. Twenty-one of these responses were reported with regard to the use of the tie-down/belt system. One additional response was reported by an agency that relies on the combined use of the tie-down/belt system and wheel-lock devices.

Ten percent of respondents (eight of 82) identified inadequate securement of mobility aid devices as a disadvantage of using a particular securement system. Respondents reporting primary use of the tie-down/belt system gave six of these responses. One response was given with regard to the use of wheel-lock devices and another was given with regard to the use of the docking interface system. Specifically, eight of the 82 respondents noted that their securement devices do not work well with some of the newer wheelchairs, and scooters, in particular. Nearly all of the eight respondents who cited difficulty with securing scooters with their devices most often use tie-down/belt systems. Only one of these respondents reported using wheel-lock devices most often.

Other disadvantages identified by respondents include the possibility of passenger injury, damage to mobility aid devices, maintenance problems, possibility of driver/operator injuries, inability to secure a wide variety of devices, the need for additional training of drivers/operators, and driver/operator difficulties encountered during securement. Another disadvantage described by several respondents was that their securement system requires that operators have close contact with passengers in mobility devices. Finally, one respondent noted that loose belts from securement devices not in use present a safety hazard for other passengers on the vehicle.

Finally, many respondents reported no disadvantages associated with the securement device most often used by their agency. In fact, 22 percent of respondents (18 of 82) could not 
identify any disadvantages associated with using their current securement system. Thirteen of these responses were reported with regard to the use of the tie-down/belt system. Three were reported with regard to the use of wheel-lock devices. One respondent reported no disadvantages associated with the combined use of the tie-down/belt system and wheel-lock devices, and one expressed this same sentiment in relation to the combined use of the tiedown/belt system, wheel-lock devices, and the t-bar.

\section{Time Required to Secure Mobility Aid Devices}

As discussed previously, many respondents indicated that the amount of time required to secure mobility aid devices is of concern to agencies. This issue is also commonly discussed in the transit industry in relation to challenges presented by wheelchair securement. Agency responses related to the average amount of time required to secure mobility aid devices in transit and paratransit vehicles provide insight into the basis of this concern. When queried about the approximate time required to secure mobility aid devices in agency vehicles, nearly half of respondents ( 46 percent) indicated that it takes between three and five minutes to secure devices. Thirty percent of respondents reported that between one and three minutes are required to complete wheelchair securement. Another ten percent of respondents indicated that securement takes more than 5 minutes. Finally, five percent of survey participants indicated that only one minute or less is required to secure mobility devices in agency vehicles. It should be noted that the finding that 56 percent of respondents require from three minutes to more than 5 minutes to complete wheelchair securement suggests that this process may have a negative impact on agency on-time performance.

Table 12

Q.27 - On average, how much time is required to secure mobility aid devices using the securement system(s) on your agency's vehicles?

\begin{tabular}{|l|r|r|}
\hline & Frequency & \multicolumn{1}{|c|}{ Percent } \\
\hline One minute or less & 5 & $5 \%$ \\
Between 1 and 3 minutes & 29 & $30 \%$ \\
3 to 5 minutes & 44 & $46 \%$ \\
More than 5 minutes & 9 & $10 \%$ \\
Blank/no answer & 8 & $9 \%$ \\
Total & 95 & $100 \%$ \\
\hline
\end{tabular}




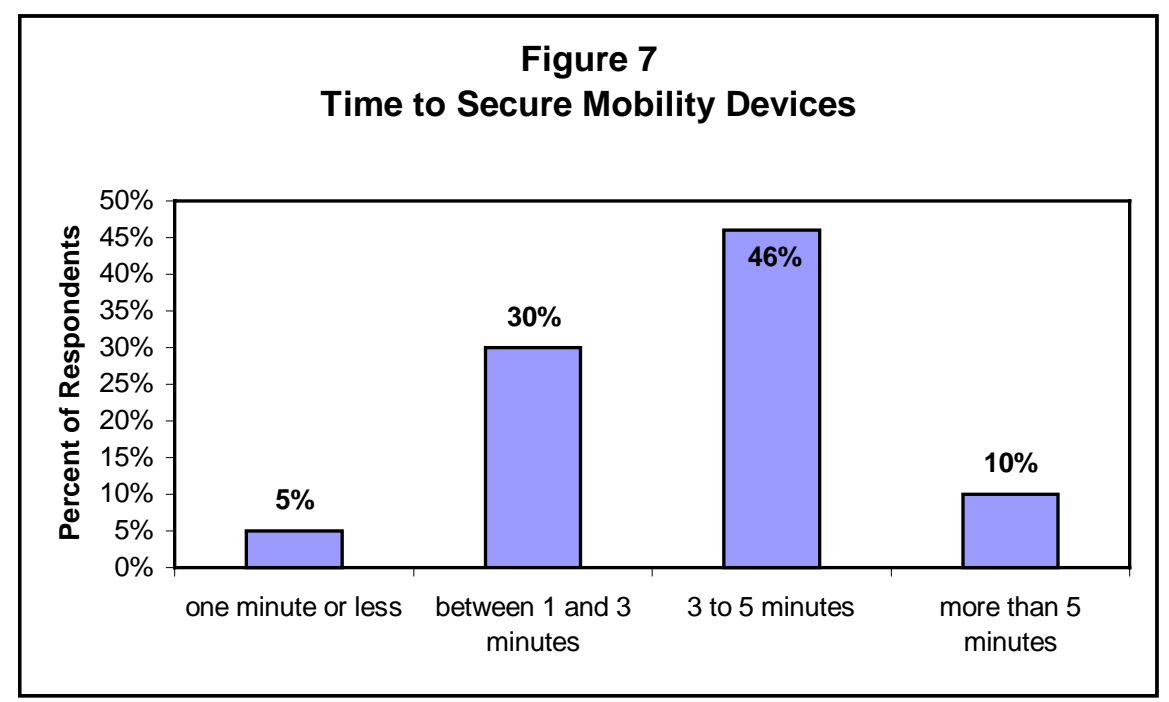

\section{Securement Devices Selection Criteria}

In addition to collecting information about the types of securement equipment utilized by survey respondents, agencies were also asked about the criteria applied in selecting the type(s) of securement device used in agency vehicles. The full range of potential criteria included in the survey is presented in Table 13, shown below. As illustrated in Table 13, system flexibility was the most commonly cited selection criteria reported, with 70 percent of respondents indicating that they had considered the system's ability to be used with many types of mobility aid devices. Fifty-six percent of the survey participants identified ease of use as a criterion used in securement device selection. Safety is also clearly a factor in these decisions, as 54 percent of respondents indicated that they selected a device because they "believe it is the safest product." Fifty-three percent of respondents cited the "structural integrity" of a particular securement device in making their decision. In addition, 45 percent of respondents indicated that the overriding selection factor was that the securement device was "standard equipment included with vehicle purchase." Another 45 percent reported that the time required to secure mobility aid devices was a factor of their decision. Forty-one percent indicated that they also considered the product's reputation when selecting a device. Finally, 13 percent of respondents marked "other" when responding to this question. The "other" category of responses included standardization of the agency fleet, maintenance cost, emergency evacuation, DOT certification and ADA approval. 
Table 13

Q.24 - When selecting the type(s) of securement device for your agency's vehicle, which of the following criteria did you use?

\begin{tabular}{|c|c|c|c|c|}
\hline \multirow[b]{2}{*}{ Criteria used in selection: } & \multicolumn{2}{|c|}{ Selected } & \multicolumn{2}{|c|}{ Not selected } \\
\hline & Frequency & Percent & Frequency & Percent \\
\hline Cost to install and maintain & 33 & $35 \%$ & 62 & $65 \%$ \\
\hline Standard equipment included with vehicle purchase & 43 & $45 \%$ & 52 & $55 \%$ \\
\hline Most common device available & 22 & $23 \%$ & 73 & $77 \%$ \\
\hline Cost of equipment & 29 & $30 \%$ & 66 & $70 \%$ \\
\hline Time required to secure mobility aid devices & 43 & $45 \%$ & 52 & $55 \%$ \\
\hline Vendor recommendation & 17 & $18 \%$ & 78 & $82 \%$ \\
\hline Structural integrity of securement device & 50 & $53 \%$ & 45 & $47 \%$ \\
\hline Believe is the safest product & 51 & $54 \%$ & 44 & $46 \%$ \\
\hline Reputation of the product & 39 & $41 \%$ & 56 & $59 \%$ \\
\hline Ease of installation & 24 & $25 \%$ & 71 & $75 \%$ \\
\hline Ease of operator training & 49 & $52 \%$ & 46 & $48 \%$ \\
\hline Ability to be used with many types of mobility devices & 67 & $70 \%$ & 28 & $30 \%$ \\
\hline Ease of use & 53 & $56 \%$ & 42 & $44 \%$ \\
\hline Quick emergency evacuation & 35 & $37 \%$ & 60 & $63 \%$ \\
\hline Less impact on vehicle passenger capacity & 23 & $24 \%$ & 72 & $76 \%$ \\
\hline Other & 12 & $13 \%$ & 83 & $87 \%$ \\
\hline
\end{tabular}

Note: The table above shows whether respondents selected or did not select each of the categories listed in response to the question above. Only valid responses are shown.

\section{Selection Criteria with Greatest Impact}

Survey respondents were then asked to indicate which one of the criteria listed above had the greatest impact on the agency's decision to purchase the selected securement equipment. According to Table 14, flexibility was the most often-cited selection factor reported. Fifteen percent of respondents indicated that they considered the ability to use the securement equipment with many types of mobility aid devices as having the greatest impact on the decision to purchase the agency's selected securement device. Safety also ranked highly with 12 percent of respondents reporting that the belief that the securement device was the safest product available had the greatest impact on the decision to purchase a particular securement system. Eleven percent noted that the most important selection factor was that the securement system was standard equipment in all vehicles purchased. Another 11 percent identified the ease of use associated with a securement device as having the greatest impact on the agency's decision to purchase. Seven percent of respondents identified the time required to secure mobility aid devices with that system as the most important factor in their decision. Only six percent of respondents cited cost as a deciding factor in the selection of securement equipment. Six percent of respondents cited the structural integrity of the securement device as a prime consideration during vehicle purchase. Finally, three percent identified DOT certification or ADA approval of a particular device. 
Table 14

Q.25 - Which one of the criteria listed had the greatest impact on your decision to purchase the selected securement device?

\begin{tabular}{|l|r|r|}
\hline Criteria used in selection: & Frequency & Percent \\
\hline Safety & 11 & $12 \%$ \\
Ability to be used with many types of mobility devices & 14 & $15 \%$ \\
Ease of use & 10 & $11 \%$ \\
Cost & 6 & $6 \%$ \\
Standard equipment & 10 & $11 \%$ \\
Structural integrity of securement device & 6 & $6 \%$ \\
Time required to secure device & 7 & $7 \%$ \\
Reputation of the product & 1 & $1 \%$ \\
Ease of installation & 1 & $1 \%$ \\
Ease of operator training & 1 & $1 \%$ \\
Quick emergency evacuation & 1 & $1 \%$ \\
DOT certified/ADA approved & 3 & $3 \%$ \\
Most common device available & 1 & $1 \%$ \\
Blank/not applicable & 23 & $24 \%$ \\
Total & 95 & $100 \%$ \\
\hline
\end{tabular}

\section{Mobility Device Accommodation Challenges and Strategies}

One of the primary goals of the Securement Device Options and Strategies Survey was to collect information on the variety of securement experiences and issues facing transit and paratransit agencies. Survey participants were queried about the types of mobility aids most commonly used by passengers and any existing policies related to the use and/or accommodation of mobility devices that do not meet the definition of a "common wheelchair." Agencies were also asked to provide information about how drivers typically respond to passengers who use non-common wheelchairs. Related issues covered by the survey that were addressed by respondents include information on the strategies developed and applied to alleviate securement challenges and/or problems presented by both non-common and common wheelchairs. The responses provided to these and other questions related to the accommodation of mobility devices on transit and paratransit vehicles illustrate the variety of securement issues still plaguing agencies, as well as many creative solutions that have been developed to ensure that, whenever possible, transportation services are provided to all passengers with disabilities who desire to use public transportation. 
Mobility Devices That Do Not Meet the Definition of "Common Wheelchair"

Survey respondents were asked if any of their passengers ever use mobility aid devices that do not fit the definition of "common wheelchair" as specified in the ADA of 1990 in order to determine how often agencies are confronted with the need to secure non-common wheelchairs. (The ADA defines a "common wheelchair" as a mobility device that is not longer than 30 inches in width, 48 inches in height, and weighs no more than 600 pounds when occupied.) Table 15 and Figure 8 show that 63 percent of respondents reported that their passengers do indeed use mobility aid devices that do not fit the ADA definition.

Table 15

Q.6 - Do any of your passengers use mobility aid devices that do not fit the definition of "common wheelchair," as specified in the ADA of 1990?

\begin{tabular}{|l|r|r|}
\hline & Frequency & Percent \\
\hline Yes & 60 & $63 \%$ \\
No & 32 & $34 \%$ \\
Blank/no answer & 2 & $2 \%$ \\
Not applicable & 1 & $1 \%$ \\
Total & 95 & $100 \%$ \\
\hline
\end{tabular}

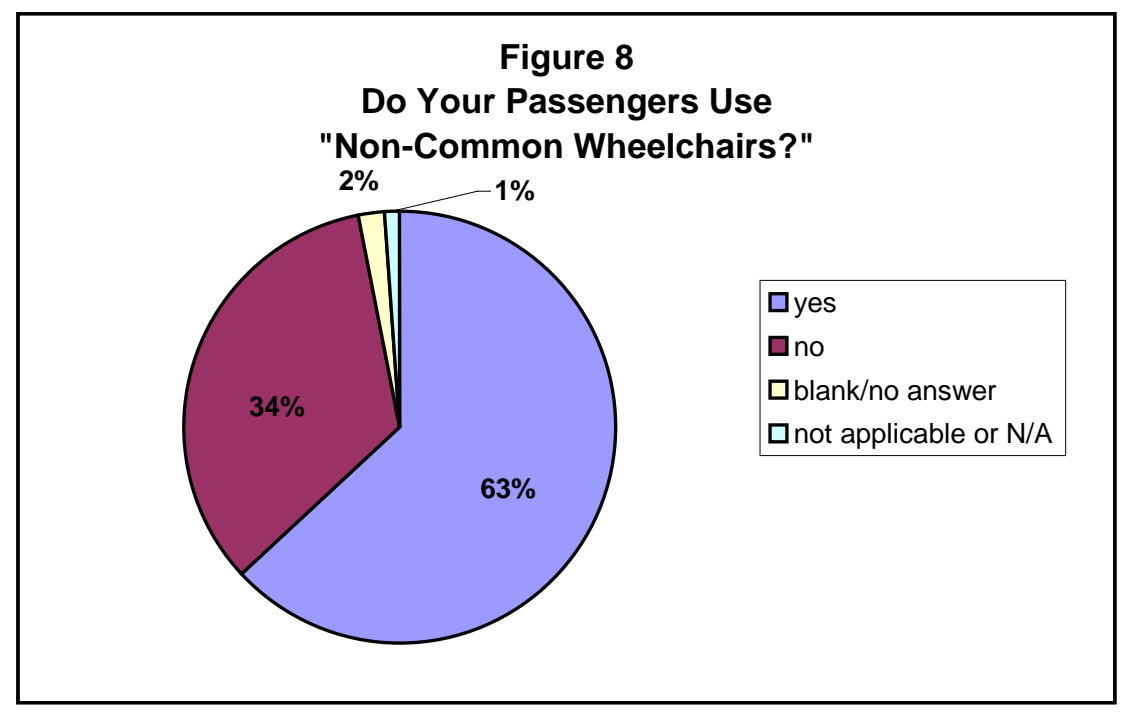

Respondents were given the opportunity to provide additional commentary with regard to the use of mobility aid devices that do not fit the definition of "common wheelchair." Twenty-nine percent (28 of 95) of respondents provided additional commentary. Most of these comments involved the use of chairs that exceed the dimensions established by the ADA. Specifically, 18 of the respondents said that some of their passengers use oversized devices. Several of the 
responding transit and paratransit providers acknowledged that, in addition to larger wheelchair sizes, they are faced with securing mobility devices that exceed allowable weight limits due to use by obese passengers. While three- and four-wheel scooters generally do not exceed the dimensions of a "common wheelchair" established by the ADA, five of the respondents to this question listed these devices as examples of "non-common wheelchairs." These responses suggest that some confusion still exists over whether or not scooters are considered "common wheelchairs" and further illustrates the need for policy clarification. Overall, devices larger or heavier than the "common wheelchair" were most commonly identified as making the mobility device securement process difficult or altogether impossible.

\section{Ability to Secure "Non-Common Wheelchairs"}

Respondents were also asked about their ability to secure mobility aid devices on their vehicles that do not meet the definition of "common wheelchair." Respondents were asked to provide information about the vehicles on which such mobility devices can be secured. Table 16 and Figure 9 reveal approximately half of the respondents (48 of 95) indicated that they are able to secure these devices "only on some vehicles." Twenty-six percent of survey participants indicated that they are able to secure non-common wheelchairs "on all vehicles." However, 17 percent of respondents indicated that they are not able to secure mobility devices that do not fit the definition of "common wheelchair" on any of their agency's vehicles.

Table 16

Q.7 - Are you able to secure mobility aid devices that do not fit the definition of "common wheelchair" with an ADA-compliant securement system on your vehicles?

\begin{tabular}{|l|r|r|}
\hline & Frequency & \multicolumn{1}{|c|}{ Percent } \\
\hline Yes, on all vehicles & 25 & $26 \%$ \\
No, not on any vehicles & 16 & $17 \%$ \\
Only on some vehicles & 48 & $50 \%$ \\
Blank/no answer & 1 & $1 \%$ \\
Not applicable & 5 & $5 \%$ \\
Total & 95 & $100 \%$ \\
\hline
\end{tabular}




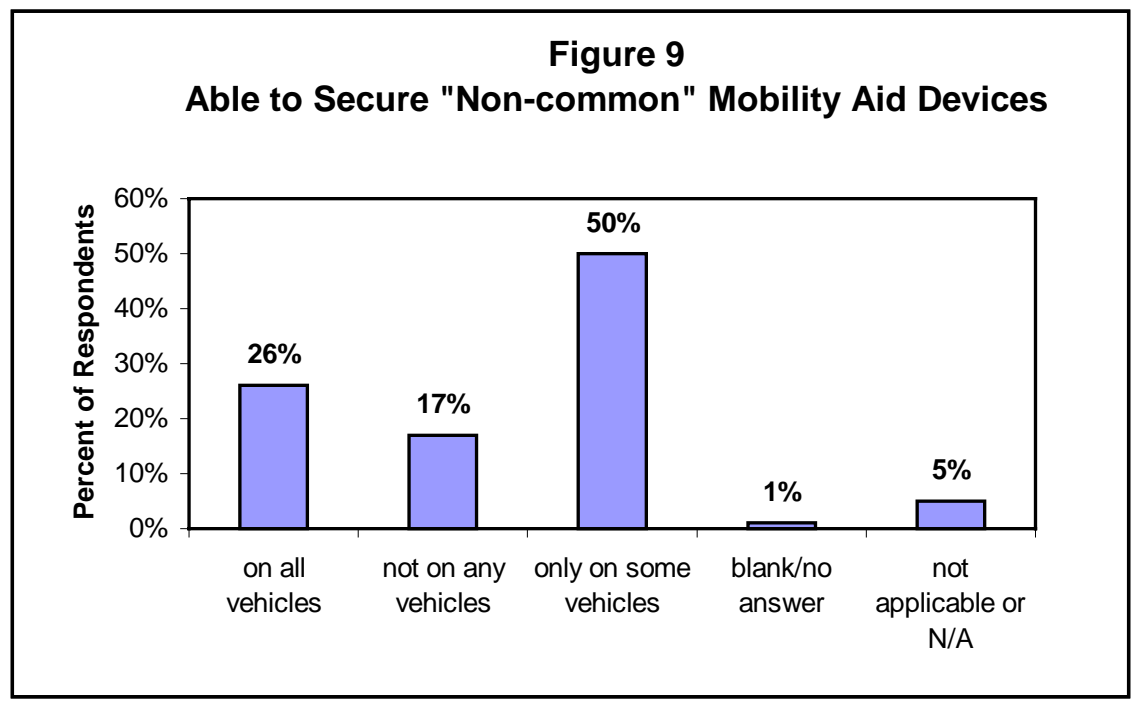

As shown in Table 17, agency responses were compared to determine whether or not respondents that indicated that their passengers use mobility aid devices that do not fit the definition of "common wheelchair" are able to secure such devices in agency vehicles. Only 93 percent (88 of 95 respondents) of total responses were used to make this determination, eliminating all those who did not reply to either question or indicated that it was not applicable to their situation. Forty-nine percent (43 of 88) of those who indicated that their passengers use mobility aid devices that do not fit the definition of "common wheelchair" indicated that they are able to secure such devices "only on some vehicles." Only 14 percent (12 of 88) of respondents who reported passengers who use non-common wheelchairs also indicated that they are able to secure such mobility devices "on all vehicles."

Table 17

Ability to Secure "Uncommon" Wheelchairs and Passenger Use Compared

\begin{tabular}{|lcc|}
\hline & $\begin{array}{l}\text { Do any of your passengers use } \\
\text { mobility aid devices that do not fit } \\
\text { the definition of "common W/ C"? }\end{array}$ \\
\hline $\begin{array}{l}\text { Are you able to secure mobility aid devices that } \\
\text { do not fit the definition of "common wheelchair"? }\end{array}$ & $\underline{\text { yes }} \underline{\underline{\text { no }}}$ \\
Yes, on all vehicles & $14 \%$ & $14 \%$ \\
No, not on any vehicles & $6 \%$ & $13 \%$ \\
Only on some vehicles & $49 \%$ & $6 \%$ \\
\hline
\end{tabular}

Note: The results of a chi-square test for this comparison are 0.00, which fall below the significance level of 0.05 . It can therefore be concluded that there is a significant association between the use of mobility aid devices by agency passengers and the agency's ability to secure mobility aid devices that do not fit the definition of "common wheelchair" and that the differences in responses are significant. 


\section{Transporting Passengers with Non-Common Mobility Devices}

According to the ADA, public transportation providers are required to provide transportation to individuals using "common wheelchairs," as well as installing and using ADA-compliant securement equipment necessary to secure such devices during transport. Of particular interest to this study are the formal policies that transportation agencies have developed to address the transport and securement of "non-common wheelchairs" (those mobility devices that exceed 30 inches in width and 48 inches in length or weighs more than 600 pounds when occupied, as prescribed by the ADA). When queried about the formal policies related to the securement of non-common wheelchairs that have been developed by agencies to provide direction related to transportation requests from passengers using such devices, survey participants were divided nearly in half in terms of the responses received. As illustrated in Table 18, 46 percent of respondents indicated that their agency does have a formal policy related to the transport of non-common wheelchairs in place, while 44 percent indicated that they do not. Four percent said that they did not know if their agency has such a policy in place. These results indicate that, while 80 percent of the responding agencies (76 of 95) require securement and have policies reflecting such, less than half provide formal policy direction regarding mobility devices that exceed dimension and weight limits assigned to "common wheelchairs."

Table 18

Q.10 - Does your agency have a formal policy regarding the accommodation of mobility aid devices that do not meet the definition of "common wheelchair"?

\begin{tabular}{|l|r|r|}
\hline & Frequency & \multicolumn{1}{|c|}{ Percent } \\
\hline Yes & 44 & $46 \%$ \\
No & 42 & $44 \%$ \\
Don't know & 4 & $4 \%$ \\
Blank/no answer & 4 & $4 \%$ \\
Not applicable or N/A & 1 & $1 \%$ \\
Total & 95 & $100 \%$ \\
\hline
\end{tabular}

Respondents were asked to "briefly describe" their agency's policy regarding the accommodation of mobility aid devices that do not meet the definition of "common wheelchair." This question elicited a 75 percent response rate, with 72 of 95 responses. The open-ended responses received highlight the effort made by many agencies to accommodate and secure all mobility aid devices. However, there was a definite split among respondents' characterization 
of their agency's securement policy. A number of respondents expressed an inability to secure devices that do not fit the definition of "common wheelchair." Further, 32 percent (23 of 72) of those responding to this question noted that their agency actively discourages the transport of any device that does not meet the ADA definition. For instance, one respondent indicated that when faced with transporting a passenger using a device that does not meet the definition of "common wheelchair," the agency policy requires that the passenger meet with a transit supervisor to discuss alternatives or refers them to paratransit service. Also, several of the respondents noted that their policy to not accommodate oversized mobility devices was developed in response to wheelchair lift capacities more than to securement capabilities. Conversely, another 32 percent of these respondents indicated that agency policy stresses accommodation of all passengers with disabilities. Several of these respondents employ policies that allow for the accommodation of any device, regardless of size, as long as it safely fits on the wheelchair lift.

\section{Driver Responses to Non-common Wheelchairs}

Respondents were asked to indicate how operators most often respond to passengers with mobility devices that do not fit the definition of "common wheelchair" -- a mobility device that is larger than 30 inches in width, 48 inches in height, and weighs more than 600 pounds when occupied. Responses to this question again indicate that most agencies are doing their best to secure all mobility devices. A full 40 percent of respondents indicated that their operators would allow boarding and secure the device to the best of their ability. As Table 19 and Figure 10 indicate, only four percent of respondents reported that their operators would deny the trip to a passenger using a non-common wheelchair. Eighteen percent indicated that their operators request from dispatchers an alternative vehicle that is better able to accommodate non-common mobility devices. Eleven percent of respondents indicated that their operators would allow boarding and request that the passenger transfer to a vehicle seat. Finally, 14 percent of respondents marked "other" with regard to operator responses to non-common wheelchairs. Most of the respondents ( 8 of 13 or 62 percent) who marked "other" indicated that operators most often request assistance from supervisors, dispatchers, or other agency staff. Other responses to this question included asking passengers to transfer to a common wheelchair and referring passengers to paratransit service. 
Table 19

Q. 15 - Which of the following statements best describes how your drivers most often respond to passengers with mobility aid devices that do not fit the definition of "common wheelchair"?

\begin{tabular}{|l|r|r|}
\hline Operators would: & Frequency & Percent \\
\hline Deny the trip & 4 & $4 \%$ \\
Request a different vehicle from dispatcher & 17 & $18 \%$ \\
Allow boarding and secure device to best ability & 38 & $40 \%$ \\
Allow boarding and request that passenger transfer to a seat & 10 & $11 \%$ \\
Other & 13 & $14 \%$ \\
\hline
\end{tabular}

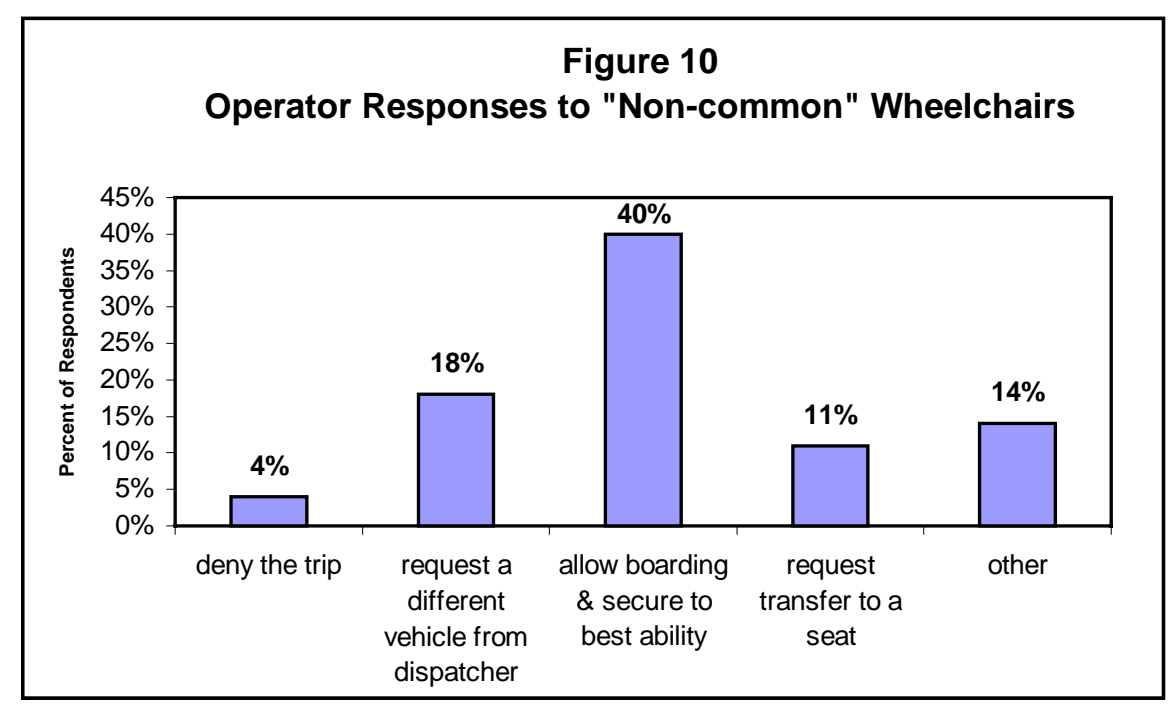

Strategies to Accommodate "Non-Common Wheelchairs"

As described above, the majority of operators appear to respond to passengers using noncommon wheelchairs by allowing boarding and attempting to secure the mobility device to the best of their ability. As a follow-up to this question, respondents were also asked to describe strategies that have been developed by agencies in order to accommodate mobility aid devices that do not meet the definition of "common wheelchair." Fifty-two survey participants used this opportunity to elaborate on strategies developed to accommodate non-standard mobility devices. One of the most common strategies identified by respondents was to refer passengers in such devices to paratransit service providers. A smaller group of respondents indicated that in the event of a situation in which a device could not be properly secured, the operator is required to call the dispatch for advice or to request a vehicle that is better able to accommodate the device. Many of the respondents again indicated that operators generally try 
to accommodate all passengers in agency vehicles. For instance, several respondents said that they are able to provide common wheelchairs on some of their vehicles to which passengers may transfer from their non-common devices. Others stated that they request that passengers transfer to a vehicle seat. Two respondents suggested that they send their most experienced drivers and most accommodating vehicles when transporting passengers with mobility devices that are known to be difficult to secure. One respondent also reported funding "wheelchair modifications" in an effort to make mobility devices more compatible with the securement equipment used on the vehicle fleet.

A strategy identified by a smaller group of respondents was active discouragement of nonstandard device use by passengers with disabilities. One respondent indicated that, although their agency currently attempts to accommodate all passengers, it expects to soon begin an educational campaign of "common wheelchair" usage by passengers and the enforcement of a new boarding policy that would exclude non-standard devices. Several respondents said that operations managers or other supervisors often evaluate their agency's ability to accommodate such devices at pre-trip meetings with passengers or during the ADA eligibility process.

Other respondents utilize strategies that focus on combining multiple types of securement devices, such as tie-down belt systems and wheel-lock devices. On the other hand, several respondents have upgraded or plan to upgrade their securement equipment to better accommodate a wider variety of mobility devices. Three respondents indicated that their agencies recently upgraded securement systems in the entire fleet in order to address the increase in passenger use of devices exceeding standard wheelchair dimensions. Four respondents did not provide specific indications of strategies for accommodation of such mobility devices; instead, reiterating agency policies stipulating that all devices must be secured and that only those devices that can be secured will be transported. Finally, two respondents said that, in an effort to accommodate all mobility devices, if passengers so request, the mobility devices would not be secured at all. 


\section{Difficulties with the Accommodation of "Common Wheelchairs"}

Responses to several of the open-ended questions included in the Securement Device Options and Strategies Survey suggest that many agencies are also experiencing securement difficulties in relation to some "common wheelchairs" used by passengers, as defined by the ADA. In a follow-up effort to the original survey, the 95 original survey respondents were contacted and asked to identify any difficulties they have experienced in relation to securing "common wheelchairs" and the strategies they have employed to overcome these challenges. Fifty-three percent ( 50 of 95 ) of the original survey participants responded to these follow-up questions. Over half (52 percent) of the follow-up respondents indicated that their agencies do have difficulty securing some "common wheelchairs." Forty-two percent indicated that they are not experiencing any difficulties while securing "common wheelchairs." An additional six percent reported that the follow-up questions were not applicable to their situation. Each of the agencies that acknowledged difficulty with securing some common wheelchairs also provided additional comments about the issue and elaborated on the strategies that they have used to accommodate common wheelchairs that are difficult to secure.

Most of the respondents suggested that scooters, although meeting the definition of a "common wheelchair," are the most difficult type of device to secure in agency vehicles. In addition, respondents identified "oversized" and electric devices, as well as "Geri-chairs" (reclining-type devices) as "common wheelchairs" that are difficult to secure. The remaining respondents who reported securement difficulties associated with "common wheelchairs" did not identify the specific types of devices that pose problems.

As suggested above, nearly half of the respondents to the follow-up questions (46 percent) reported that their operators encounter difficulties when attempting to secure three- and fourwheel scooters. Many expressed the concern that the scooters are difficult to secure because there are limited areas on these mobility devices to which tie-down straps may be effectively attached. Others noted that the scooters are quite unstable when used by occupants as a seat on transit vehicles. One respondent suggested, "The current system for securing some scooters is not fail-safe. Due to the design of scooters (three wheels, low wheels, and high center of gravity), there is an inherent tipping hazard at normal operations speed." Several survey 
participants also expressed frustration with having little-to-no guidance from manufacturers on the securement of three- and four-wheel scooters. One stated that the "manufacturer can't even suggest how to tie them down."

\section{Strategies to Accommodate Difficult to Secure "Common Wheelchairs"}

The survey follow-up questions also asked respondents to describe the strategies most often used to address the securement of "difficult common wheelchairs." Fifteen percent of the agencies reported that they recommend that passengers transfer from mobility devices that are difficult to secure to transit vehicle seats. This appears consistent with the strategy used by many agencies when faced with securing a device that does not meet the definition of a "common wheelchair." Nearly all of the responding agencies emphasized that while transferring to a seat is strongly recommended, it is never required of a passenger. However, one agency did state that if a passenger who is using a "common wheelchair" that is too difficult to secure with available equipment refuses to transfer to a vehicle seat, the passenger is denied the trip because "[the agency's] policy is not to transport if they can't or won't transfer," despite ADA regulations that state that an agency may not require passengers to transfer to a seat. This respondent further explained that scooters, in particular, are dangerous and reported that the agency is convinced that the passenger is not safe if they cannot ensure the securement of the device they are using as a seat during transport. Although not in the context of responding to a passenger's refusal to transfer from a mobility device to a seat, another agency reporting having a policy stating that, due to safety reasons, if a mobility device cannot be properly secured, the passenger cannot be transported on agency vehicles. However, it is important to emphasize that the majority of the responses received from the original survey, as well as the follow-up questions, indicate that agencies feel compelled to do their best to secure all devices, whether the devices to be secured are considered "common" or not.

Using another popular strategy, 15 percent of the respondents participate in a "chair-marking" program, which consists of the distribution of stickers to passengers to apply to their mobility devices in order to identify optimal securement locations for vehicle operators. The premise behind this program is that passengers know best how to secure their own devices. Several of those agencies not specifically reporting use of a chair-marking program did, however, state 
that they instruct their operators to ask passengers to identify the best securement locations on their particular mobility devices. There were also two respondents reported distributing tiedown straps to passengers so that they might permanently attach them to their mobility devices. This is another method of encouraging the user's assistance in establishing the best practice for securing their particular mobility device.

Other strategies identified through the results of the follow-up questions included: securing to their best ability, providing additional securement training to vehicle operators, referring passengers to paratransit service, dispatching an alternative vehicle, and deploying new securement methods. As mentioned previously, most of the respondents implied that their vehicle operators secure mobility devices to the best of their ability. Twenty-eight percent of follow-up respondents who reported encountering difficulties in relation to securing some common wheelchairs specifically identified securing the devices to the best of their ability as a strategy used by their agency. Interestingly, one respondent indicated that their short-term policy is to do their best and in the long run a supervisor will communicate with the passenger to find a solution. This respondent further stated, "it is our policy that the wheelchair will be secured, (so) it is up to us to find a way to secure the chair."

Nearly one-quarter of the respondents (24 percent or 6 of 26) who reported difficulties with securing some "common wheelchairs" also said that they provide additional training opportunities for their operators in the area of mobility aid securement. As an example of the training opportunities available, one agency said that it houses a training bus at the garage with varied mobility devices onboard so that operators can practice securing some of the more difficult devices. According to several respondents, training is the best mechanism for ensuring that the operators are confident in their abilities when securing mobility devices on transit vehicles.

At least one respondent to the follow-up questions reported either referring passengers using difficult to secure mobility devices to paratransit services or requesting an alternative vehicle to accommodate such passengers. This strategy was also mentioned several times in the comments from the original survey. Finally, some of the respondents said that they are contemplating the use of different securement devices or methods, such as the "Cleveland 
Clinic motorized belt securement" device and securing passengers in the rear-facing position, rather the current forward-facing position.

Overall, it appears clear that many public transit agencies are experiencing difficulties associated with securing "common wheelchairs," as well as "non-common wheelchairs." The strategies employed by these agencies to overcome securement challenges associated with the use of "common" devices that are of unusual shapes and sizes, lack securement points, and/or are not of adequate strength are similar to the strategies adopted in relation to "non-common wheelchairs." It appears that, in general, agencies want to accommodate all passengers and are employing several practices that allow them to do so. Toward this end, several respondents suggested that in the future the most effective strategies will involve standardizing "securement belts and floor anchors," installing interfaces on new mobility devices to be used with docking systems, and requiring wheelchair manufacturers to identify tie-down points on wheelchairs that will afford the safest securement on transit vehicles.

The range in responses to questions related to the accommodation of common and noncommon wheelchairs illustrate a continuum of sorts upon which agency policies and strategies may fall. This continuum may be seen as ranging from strict adherence to a policy of accommodating only "common wheelchairs" on one end, and efforts to accommodate any mobility device encountered on a route, on the other. While there was a clear split evident in the responses to these questions, in general, agencies appear to fall somewhere between these two extremes, suggesting that they reserve some flexibility in responding to passengers with disabilities who use mobility aid devices. However, one might surmise that this flexibility emerges out of a lack of standardization and/or guidance with regard to adherence to ADA requirements.

\section{Securement-related Trip Denials}

As described previously, agencies appear to be making every effort to accommodate all persons using mobility devices, no matter the type or size of the device. However, the survey findings also illustrate that there are some reasons and situations that result in trip denials. Specifically, survey respondents were asked to identify the securement-related reasons that operators may 
deny a trip to passengers using mobility aid devices. Survey participants were asked to select all applicable responses from a list provided, shown in Table 20. Table 20 and Figure 11 show the number of times all respondents selected one or more of the provided responses. Thirtyone percent of respondents indicated that their operators have not denied passenger trips. Forty-three percent of respondents indicated that operators have denied passenger trips because the mobility aid device was too large to be accommodated by accessibility equipment. This presumably includes devices that are not considered "common wheelchairs," but could also refer to devices that are simply larger than what is able to be accommodated by vehicles (whether common or not) - assuming that the vehicle is not accessible to persons using mobility devices. Twenty-five percent of the participants indicated that their operators have denied trips to passengers who refuse to allow the securement of their mobility devices. This complements survey findings discussed previously that reveal that 88 percent of survey participants have a policy requiring the securement of mobility devices during transport (see Table 6). Twenty percent of respondents indicated that operators have denied passenger trips because due to the inability to secure mobility devices with the existing securement system. The remaining eight percent of respondents reported that vehicle operators have denied passenger trips due to malfunctioning securement equipment. When the responses related to malfunctioning or inadequate securement devices are combined, nearly 30 percent of respondents report that these issues have resulted in the denial of transportation to passengers using mobility devices, despite ADA requirements that all common wheelchairs be secured with ADA-compliant securement equipment and the maintenance and upkeep of such equipment. This finding is consistent with complaints received by FTA's Office of Civil Rights, which suggest that some passengers who use mobility devices are being turned away by transportation providers because their devices cannot be secured (American with Disability Act Letters of Finding [37.161 and 37.165] accessed at http://www.fta.dot.gov/office/civrights/lof/lof.html, October 2001).

Twenty-two respondents marked "other" in responding to the question regarding operatorinitiated trip denials. Four of these respondents reported that operators might deny trips in the event that passengers and devices, together, are too big or too heavy to be accommodated by vehicle wheelchair lifts. Additionally, four respondents indicated that drivers might deny trips as a result of malfunctioning wheelchair lift equipment. At least two of the respondents who 
marked "other" suggested that vehicle operators are not authorized to deny passenger trips. Additional responses received include passenger inability to handle their mobility device once onboard the vehicle, no vacant securement locations, disruptive passengers, driver concerns related to passenger safety, passenger refused to transfer to a seat or "common wheelchair", health hazards associated with transportation of bodily fluids, and faulty braking systems on mobility devices. Although it is not clear if all of the reasons cited for operator-initiated trip denials are permissible under the ADA (due to variations in agency policy), it is obvious that passengers who use mobility devices are being denied transportation for an array of reasons. However, the majority of driver-initiated trip denials appear to be related to securement device type and condition, as well as the size of mobility devices.

Table 20

Q12 - For what reasons have your operators denied a trip to a passenger in a mobility aid device?

\begin{tabular}{|l|r|r|r|r|}
\hline & \multicolumn{2}{|c|}{ Selected } & \multicolumn{2}{c|}{ Not selected } \\
\cline { 2 - 5 } & Frequency & Percent & Frequency & \multicolumn{1}{c|}{ Percent } \\
\hline Not applicable & 29 & $31 \%$ & 66 & $70 \%$ \\
Too big & 41 & $43 \%$ & 54 & $57 \%$ \\
Passenger refused to be secured & 24 & $25 \%$ & 71 & $75 \%$ \\
Unable to secure device & 19 & $20 \%$ & 76 & $80 \%$ \\
Unfamiliar with equipment & 2 & $2 \%$ & 94 & $98 \%$ \\
Unfamiliar with device & 1 & $1 \%$ & 94 & $99 \%$ \\
Securement equipment broken & 8 & $8 \%$ & 87 & $92 \%$ \\
Other & 22 & $23 \%$ & 73 & $77 \%$ \\
\hline
\end{tabular}

Note: The table above shows whether respondents selected or did not select each of the categories listed in response to the question above. The indicated "not applicable" responses are considered to mean that their operators do not deny trips to passengers in a mobility aid devices.

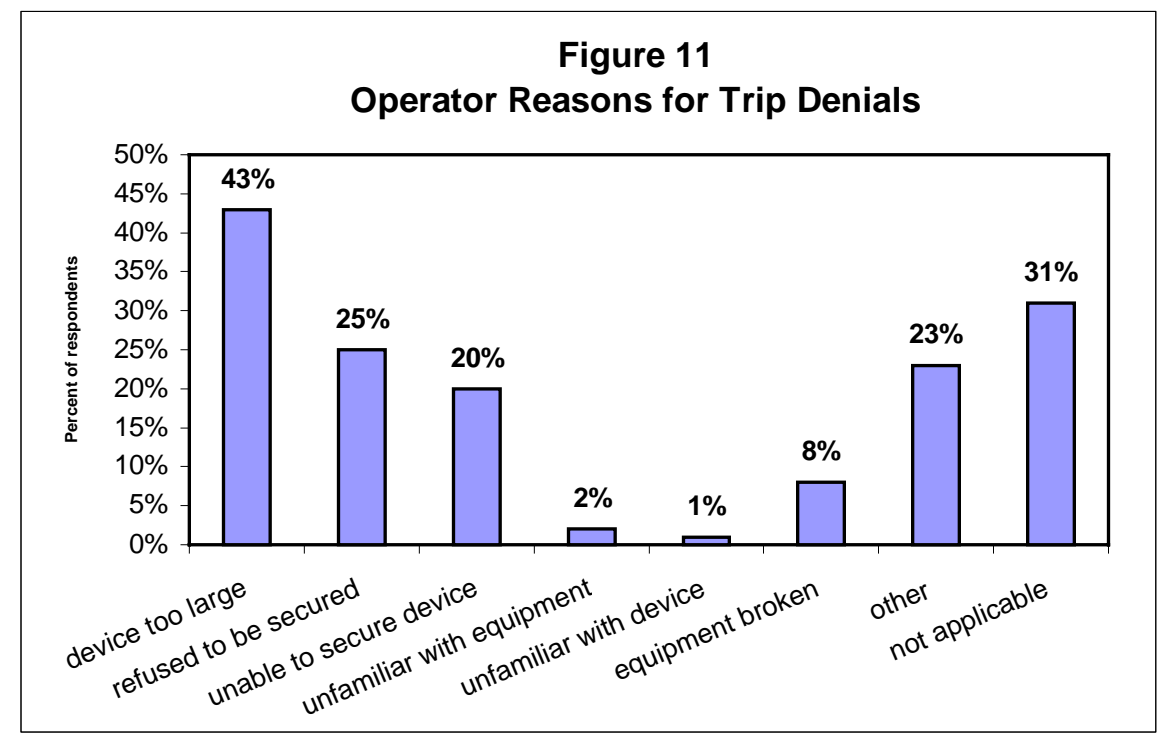




\section{Securement-related Complaints}

Passengers and vehicle operators are often the most useful resource for the identification of operational problems and issues due to their extensive first-hand knowledge of existing services. Survey participants were asked to provide information about any securement-related complaints that have been lodged by passengers and vehicle operators. The responses received provide some insight into the securement issues of greatest concern to passengers who use mobility devices and drivers who are required to secure the mobility devices used by those passengers.

\section{Passenger Complaints}

As described previously, passengers have concerns of their own regarding mobility device securement. In an effort to identify perceived passenger issues related to securement on transit vehicles, survey respondents were asked to note the types of securement-related complaints their agencies have received from riders. They were asked to select all applicable complaints from a list provided, shown in Table 21 below. The survey respondents were also offered an opportunity to describe secure-related complaints not suggested on the list provided. Table 21 and Figure 12 indicate that just over half of the respondents surveyed (51 percent) reported that passengers using mobility devices have complained that they do not want their devices to be secured. Nearly half of the survey respondents (49 percent) also reported that riders have complained that the securement equipment used in agency vehicles causes damage to their mobility devices. Interestingly, 32 percent of survey respondents also reported that riders do not want to be assisted by the driver, while 27 percent said that passengers have reported not feeling safe despite the securement of their mobility device. Eight percent of respondents indicated that passengers who use mobility devices have complained about the position of their secured mobility devices during transport.

Fifteen percent of respondents marked "other" in response to the question related to securement-related complaints issues by passengers. The "other" responses received were related to passenger discomfort due to the tightness of belts/straps, equipment that is unable to secure mobility devices properly, soiled belts or tie-down straps, discontent related to 
transfer policies (i.e. requiring transfer from mobility device to vehicle seat), and inappropriate contact by drivers during securement. However, over half of those who provided additional information (57 percent or 8 of 14) said that their agency or department has not received any securement-related complaints from passengers.

Table 21

Q. 13 - What complaints have you received from riders regarding securement?

\begin{tabular}{|c|c|c|c|c|}
\hline \multirow[b]{2}{*}{ Passengers: } & \multicolumn{2}{|c|}{ Selected } & \multicolumn{2}{|c|}{ Not selected } \\
\hline & Frequency & Percent & Frequency & Percent \\
\hline Do not want to be secured & 48 & $51 \%$ & 47 & $49 \%$ \\
\hline Do not want to be assisted by driver & 30 & $32 \%$ & 65 & $68 \%$ \\
\hline Securement equipment damages mobility aid device & 47 & $49 \%$ & 48 & $51 \%$ \\
\hline Do not feel safe & 26 & $27 \%$ & 69 & $80 \%$ \\
\hline Securement equipment does not work properly & 11 & $12 \%$ & 84 & $88 \%$ \\
\hline Driver does not know how to use equipment properly & 28 & $30 \%$ & 67 & $70 \%$ \\
\hline Do not like position of mobility aid device while riding & 23 & $24 \%$ & 72 & $76 \%$ \\
\hline Other & 14 & $15 \%$ & 81 & $85 \%$ \\
\hline
\end{tabular}

Note: The table above shows whether respondents selected or did not select each of the categories listed in response to the question above. Only valid responses are shown.

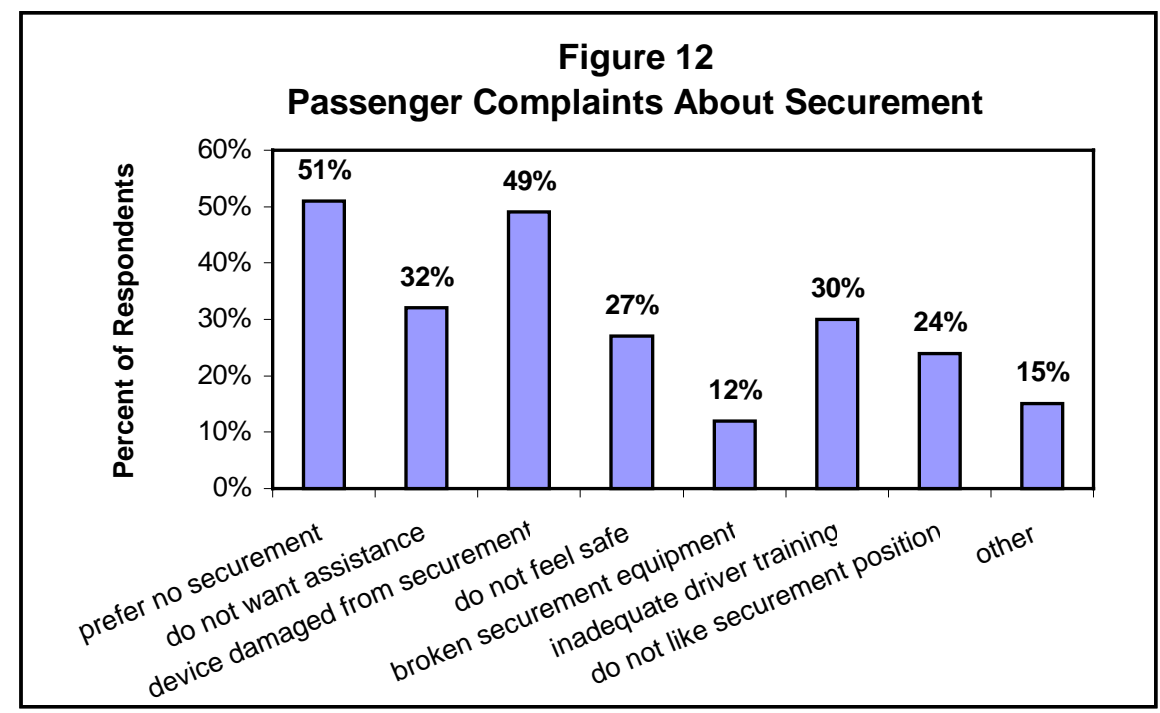

\section{Operator Complaints}

Respondents were also asked to indicate the types of complaints they have received from operators regarding the securement of mobility aid devices. Table 22 and Figure 13 show the number of times all respondents selected one or more of the provided responses related to operator complaints. Fifty percent of survey respondents indicated that operators have complained that passengers do not want to have their mobility devices secured during 
transport. Just over half of the respondents (54 percent) reported that operators complain about the amount of time required to secure mobility devices on transit and paratransit vehicles. This complaint is consistent with information received related to the average amount of time required to secure mobility devices on agency vehicles. As described previously, the majority of survey respondents indicated that securing mobility devices on agency vehicles requires three or more minutes per device to complete. Additionally, 42 percent of survey participants reported that operators have complained that mobility device securement is too difficult. A full 28 percent of respondents indicated that vehicle operators complain about securement equipment that does not work properly. Seventeen percent of survey respondents reported that vehicle operators do not want to assist passengers using mobility devices with securement. Finally, 12 percent of survey participants also indicated that operators complain about not knowing how to use securement equipment properly.

Twenty-three percent of respondents also marked "other" in relation to securement complaints received by vehicle operators. Several of the "other" responses could most appropriately be included in one of the categories identified above. For instance, one respondent reported that the "size of the mobility aid [is] too large, making it difficult to secure." Similarly, several respondents made comments regarding operator frustration with securing scooter-type devices. Both of these responses can be classified as difficult securement. Additional responses received include concern that securement equipment damages wheelchairs, frustration regarding the variety of types or makes of mobility devices that must be accommodated, difficult passengers, a lack of securement points on some types of mobility devices, and the close contact with passengers required to complete mobility device securement. The remaining 27 percent of those who marked "other" indicated that operators either do not complain or are able to adequately secure mobility devices. Interestingly, several of the complaints made by vehicle operators mirror those received by passengers (e.g. equipment damages mobility devices, lack of proper training, and malfunctioning securement equipment). 
Table 22

Q.14 - What complaints have you received from operators regarding securement?

\begin{tabular}{|c|c|c|c|c|}
\hline \multirow[b]{2}{*}{ Operator complaints: } & \multicolumn{2}{|c|}{ Selected } & \multicolumn{2}{|c|}{ Not selected } \\
\hline & Frequency & Percent & Frequency & Percent \\
\hline Passengers do not want to be secured & 47 & $50 \%$ & 48 & $50 \%$ \\
\hline Securement takes too much time & 51 & $54 \%$ & 44 & $46 \%$ \\
\hline Securement is too difficult & 40 & $42 \%$ & 55 & $58 \%$ \\
\hline Do not want to assist passengers with securement & 16 & $17 \%$ & 79 & $83 \%$ \\
\hline Do not know how to use securement equipment & 11 & $12 \%$ & 84 & $88 \%$ \\
\hline Securement equipment does not work properly & 27 & $28 \%$ & 68 & $72 \%$ \\
\hline Other & 22 & $23 \%$ & 73 & $77 \%$ \\
\hline
\end{tabular}

Note: The table above shows whether respondents selected or did not select each of the categories listed in response to the question above.

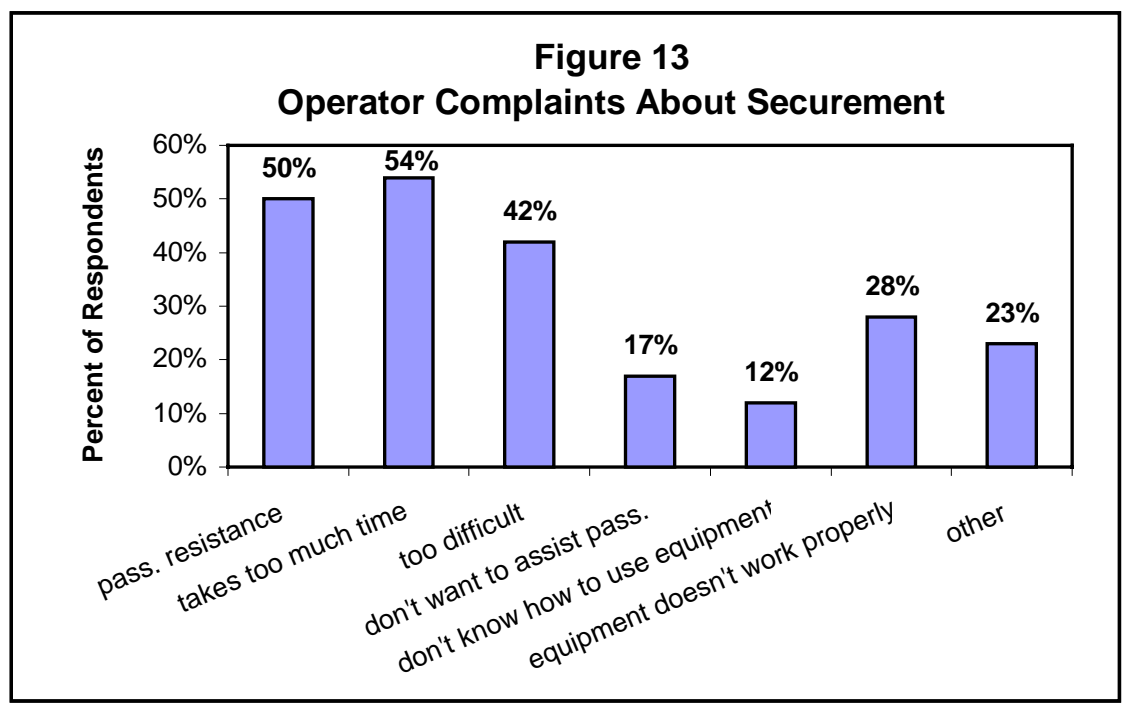

\section{Securement-Related I njuries}

Because all transportation agencies place a high premium on the safety of their passengers and operators, respondents were also asked to describe any driver, attendant, or passenger injuries occurring in the previous three years that have been associated with vehicle securement equipment or agency securement policies and/or procedures. Table 23 illustrates that 55 percent of respondents indicated that there had not been any securement-related injuries reported in the past three years. However, a full 45 percent of survey respondents indicated that there had been injuries reported in relation to the securement of mobility aid devices during the identified period of time. 
Table 23

Q.26 - Have there been any driver/attendant or passenger injuries associated with your vehicles' securement equipment or procedures in the past 3 years?

\begin{tabular}{|l|r|r|}
\hline & Frequency & Percent \\
\hline Yes & 43 & $45 \%$ \\
No & 52 & $55 \%$ \\
Total & 95 & $100 \%$ \\
\hline
\end{tabular}

In the event that securement-related injuries had occurred in the past three years, respondents were asked to provide additional detail about the incident(s). Eighty-eight percent (38 of 43) of those who reported that there had been driver, attendant, or passenger injuries associated with securement in the past three years provided additional commentary regarding such incidents. Thirty-three percent of these respondents (14 of 43) noted that problems related to securement most often resulted from improper securement by drivers or attendants. Twenty-three percent of respondents (10 of 43) referred to the tipping over of mobility aid devices, in some cases resulting in passengers being thrown to or sliding to the floor. The majority of comments related to the tipping of devices (eight of ten) again emphasized scooters as the most problematic of mobility aid devices in terms of securement. These respondents expressed the feeling that such devices could not be properly secured and were prone to tipping during vehicle transport. Five respondents noted that injuries had occurred on their vehicles when mobility devices either were not secured at all, passengers were not restrained, or passengers released their restraints or mobility device securement devices before the vehicle had come to a complete stop. Two final comments regarding incidents were related to improper securement of an unoccupied mobility device that shifted during transport and injured a nearby passenger, as well as the collapse of mobility devices that are not sturdily constructed.

Some of the respondents also described the injuries that were a result of the incidents or accidents. Specific injuries reported were most often identified as being minor ones, such as bumps on the passenger's head or body, sprains, and/or cuts and scrapes. One respondent indicated that "an extremely fragile " passenger suffered broken bones, "both in the securement process and as a result of vehicle operation." Although a singular response, it indicates the number of concerns operators and attendants must consider in the securement of passengers with disabilities. 
Finally, the responses received indicate that vehicle operators are also susceptible to securement-related injuries. Sixteen percent of respondents (seven of 43) reported driver injuries sustained as a result of securing mobility devices. These injuries were most often characterized as back strains, arm and shoulder injuries, carpel tunnel syndrome, and cuts, scrapes, or bruises. Five percent of respondents (two of 43) indicated that they were not aware of any reported injuries sustained by drivers, attendants, or passengers.

\section{Operator Training}

As many of the survey findings discussed in previous sections indicate, operator training is an essential component of safe and effective mobility device securement. As described previously, many survey respondents reported concerns related to improper mobility device securement, including passenger injuries that have resulted from faulty securement. These findings highlight the importance of driver training related to mobility device securement. Proper operator training results in securement practices that are effective, while also easing passenger and driver apprehension. Therefore, survey participants were questioned about the type and extent of mobility device securement training provided to vehicle operators.

Survey participants were asked to indicate whether or not all operators receive training on the use of securement equipment. As illustrated in Table 24, the majority of respondents (90 percent) indicated that operators do indeed receive such training. Only one respondent did not know if operators receive training.

Table 24

Q.32 - Do all operators receive training on use of securement systems?

\begin{tabular}{|l|r|r|}
\hline & Frequency & \multicolumn{1}{|c|}{ Percent } \\
\hline Yes & 85 & $90 \%$ \\
No & 0 & $0 \%$ \\
Don't know & 1 & $1 \%$ \\
Blank/no answer & 8 & $8 \%$ \\
Not applicable or N/A & 1 & $1 \%$ \\
Total & 95 & $100 \%$ \\
\hline
\end{tabular}

Respondents were also asked to indicate whether or not vehicle manufacturers or mobility device securement system vendors offered training to their vehicle operators on the use of securement equipment. Table 25 and Figure 14 show the distribution of responses received. 
Forty-one percent of the survey respondents indicated that vehicle manufacturers and/or securement equipment vendors did not provide training for vehicle operators on the use of securement equipment, while 37 percent indicated that manufacturers and/or vendors did provide such training.

Table 25

Q.24 - Did the vehicle manufacturer or securement system vendor offer training on the use of securement systems for your operators?

\begin{tabular}{|l|r|r|}
\hline & Frequency & Percent \\
\hline Yes & 35 & $37 \%$ \\
No & 39 & $41 \%$ \\
Total & 76 & $78 \%$ \\
\hline
\end{tabular}

Note: Only valid responses are shown. Nineteen respondents did not respond

to the question or marked it as not applicable to their situation. $(N=95)$

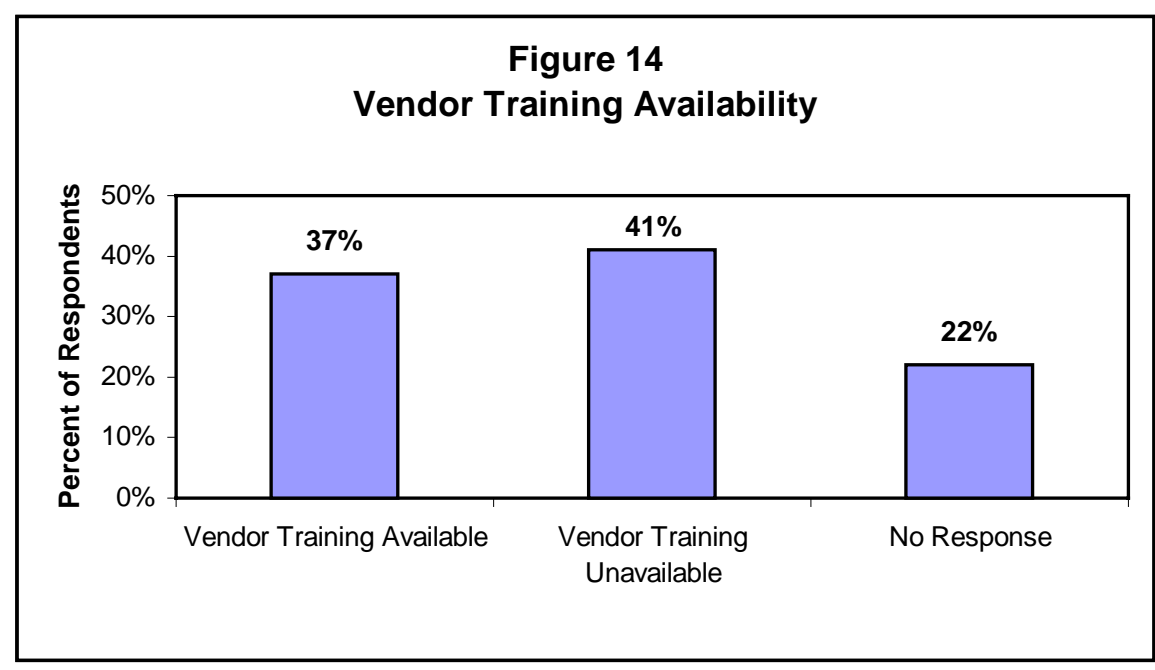

Finally, survey respondents were asked to provide additional information about the type of training that has been provided to their vehicle operators related to the use of securement devices. As shown in Table 26 and Figure 15, 75 percent of respondents reported that operators attend a mobility device securement training course. Peer-to-peer training is also prevalent with 58 percent of survey participants reporting that operators receive this training through this approach. Forty-two percent of survey participants reported that operators are provided a video course on securement practices. Another 16 percent indicated that operators receive training provided by vendors. Finally, six percent of respondents marked "other" when responding to this question. These responses included providing opportunities for vehicle operators to practice securing different types of wheelchairs, annual refresher training related 
to securement, new vehicle familiarization, sensitivity and skills courses for learning how to best deal with passengers with disabilities, and on-the-job training.

Table 26

Q.33 - What type of training on the use of securement systems is provided to operators?

\begin{tabular}{|l|r|r|r|r|}
\hline \multirow{2}{*}{ Type of training: } & \multicolumn{2}{|c|}{ Selected } & \multicolumn{2}{c|}{ Not selected } \\
\cline { 2 - 5 } & Frequency & Percent & Frequency & \multicolumn{1}{c|}{ Percent } \\
\hline Training course & 71 & $75 \%$ & 25 & $25 \%$ \\
Peer-to-peer training & 55 & $58 \%$ & 41 & $42 \%$ \\
No training is provided & 1 & $1 \%$ & 94 & $99 \%$ \\
Video course & 40 & $42 \%$ & 55 & $58 \%$ \\
Vendor training & 15 & $16 \%$ & 80 & $84 \%$ \\
Other & 6 & $6 \%$ & 89 & $94 \%$ \\
\hline
\end{tabular}

Note: The table above shows whether respondents selected or did not select each of the categories listed in response to the question above. Only valid responses are shown.

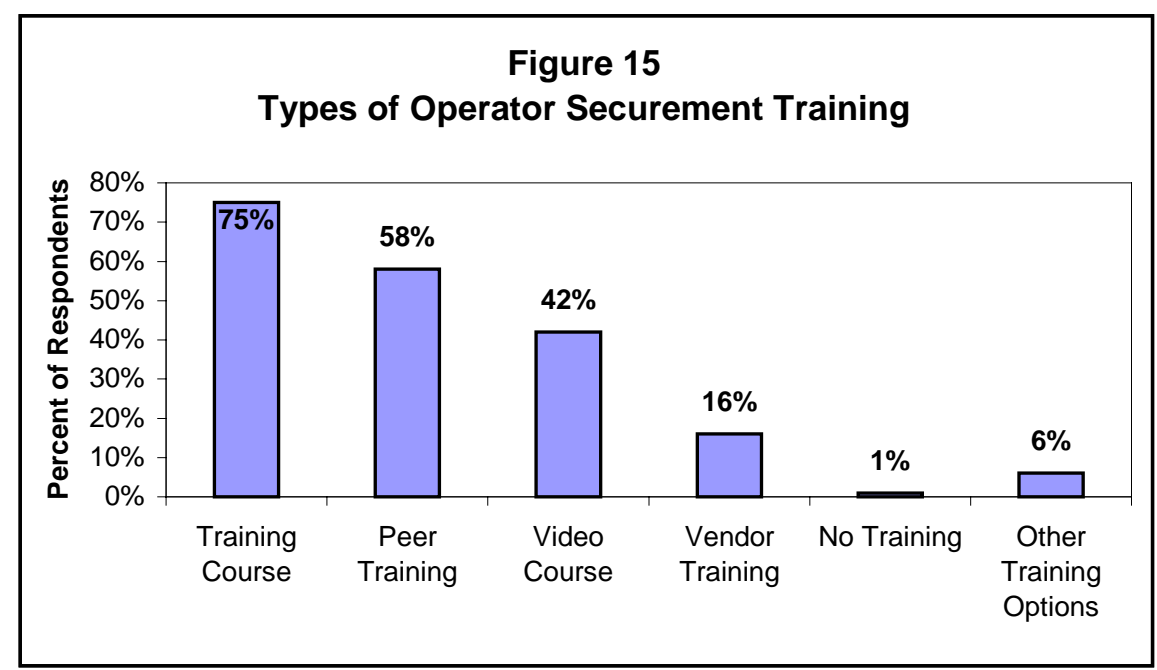

\section{Maintenance of Securement Systems}

Vehicle accessibility requirements outlined in the ADA include the maintenance and upkeep of all accessibility features, including securement equipment. To learn more about the installation, upkeep, and maintenance processes and experiences of transportation providers, survey respondents were asked to provide information about the installation and maintenance of securement systems in agency vehicles, the types of installation training provided, and how their agency responds to malfunctioning securement equipment. 
In terms of securement equipment installation, Table 27 shows that a majority of respondents (78 percent) reported that securement equipment was factory-installed as part of vehicle purchases. Six percent of respondents indicated that an outside agency or individual installs the equipment, while three percent indicated that the agency maintenance team installs the equipment. Two percent of respondents marked "other" regarding the way securement equipment is installed. One of these respondents indicated that the agency had initiated conversion of the fleet by a private company, and the other respondent (who was a paratransit provider) indicated that tie-down belts had been provided by the transit agency, although the brackets along the floors of the vehicles had been factory-installed.

Table 27

Q.28 - How is securement equipment usually installed in agency vehicles?

\begin{tabular}{|l|r|r|}
\hline & Frequency & \multicolumn{1}{|c|}{ Percent } \\
\hline Installed by maintenance team & 3 & $3 \%$ \\
Factory-installed with vehicle purchase & 74 & $78 \%$ \\
Installed by outside agency/individual & 6 & $6 \%$ \\
Other & 2 & $2 \%$ \\
Blank/No answer & 11 & $11 \%$ \\
Total & 84 & $89 \%$ \\
\hline
\end{tabular}

Respondents were also queried about the type of training provided to maintenance staff as it relates to the installation and upkeep of securement equipment. The responses to this question are included in Table 28 and Figure 16. Forty-six percent of survey participants indicated that their maintenance team received training provided by the equipment vendor.. Thirty-six percent indicated that the maintenance team attended a training course, while 34 percent said they received video training. Ten percent indicated that the maintenance team received another, not listed type of training. These responses included training conducted by wheelchair passengers themselves, completion of the American Seating full-scale operator-training module, additional operator testing, in-house training by training departments, Bianwally Training, and on-the-job training with the driver. Only eight percent of respondents indicated that the agency maintenance team receives no training related to securement equipment installation and maintenance. 
Table 28

Q.29 - What type of training related to the installation and maintenance of securement equipment does your agency's maintenance team receive?

\begin{tabular}{|l|r|r|r|r|}
\hline \multirow{2}{*}{ Type of training } & \multicolumn{2}{|c|}{ Selected } & \multicolumn{2}{c|}{ Not selected } \\
\cline { 2 - 5 } & Frequency & Percent & Frequency & Percent \\
\hline Vendor training & 44 & $46 \%$ & 51 & $54 \%$ \\
Training course & 34 & $36 \%$ & 61 & $64 \%$ \\
Video training & 32 & $34 \%$ & 63 & $66 \%$ \\
No training is provided & 8 & $8 \%$ & 87 & $92 \%$ \\
Other & 10 & $10 \%$ & 85 & $90 \%$ \\
\hline
\end{tabular}

Note: The table above shows whether respondents selected or did not select each of the categories listed in response to the question above. Only valid responses are shown.

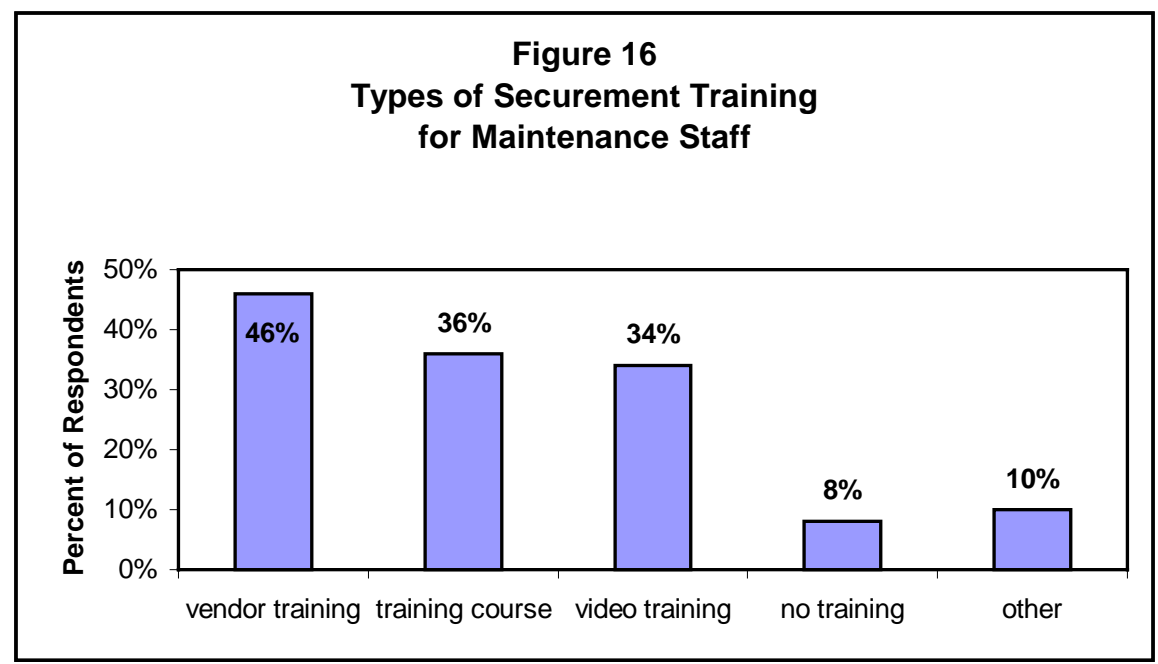

Finally, respondents were also queried about how their agency responds to malfunctioning securement equipment. As Table 29 and Figure 17 show, fifty-four percent of respondents indicated that the vehicle is immediately taken out of service until repair is completed. Sixteen percent of survey participants indicated that the vehicle remains in service until repair is scheduled, but does not transport passengers using mobility aid devices. Only five percent of respondents (5 of 82) indicated that a malfunctioning vehicle remains in service and that mobility aid devices are not secured. Twelve percent of respondents marked "other" when responding to this question. These responses included keeping extra straps/belts onboard vehicles in the event of damaged equipment, and assigning the vehicle to routes with no demand for wheelchair service. 
Table 29

Q.30 - What most often occurs if a vehicle has malfunctioning securement equipment?

\begin{tabular}{|c|c|c|}
\hline & Frequency & Percent \\
\hline Vehicle is immediately taken out of service until repair is completed & 52 & $54 \%$ \\
\hline Vehicle remains in service until repair is scheduled; MADs are not secured & 5 & $5 \%$ \\
\hline Vehicle remains in service until repair is scheduled but does not transport passengers & 15 & $16 \%$ \\
\hline Other & 11 & $12 \%$ \\
\hline Total & 82 & $87 \%$ \\
\hline
\end{tabular}

Note: Only valid responses are shown. Thirteen respondents did not respond to this question or marked it as being not applicable to their situation. $(N=95)$

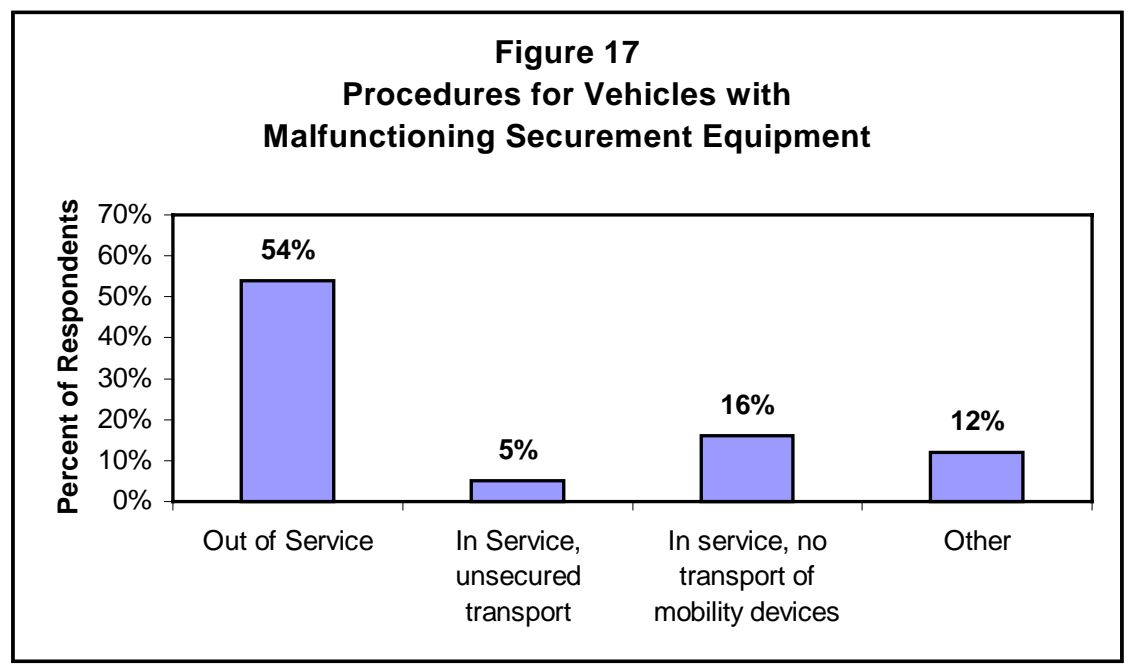

\section{Summary}

The results of Securement Device Options and Strategies Survey provide insight into the perceptions, difficulties, and strategies related to the securement of mobility devices on transit and paratransit vehicles in Florida and throughout the United States. The survey respondents reported that their passengers with disabilities use a wide variety of mobility devices, including manual and powered wheelchairs, 3- and 4-wheeled scooters, Geri-chairs, stretchers, and walkers. In terms of the equipment utilized to secure these mobility devices, tie-down/belt systems are most often used by 77 percent of the survey respondents. Wheel-lock systems are also used by several agencies, both in conjunction with tie-down/belt systems and on their own. Survey respondents reported that main advantages associated with the securement equipment most often utilized by their agencies are the flexibility associated with being able to secure a variety of mobility devices, the safety afforded when securing mobility devices, and ease of use. 
The main disadvantages reported in association with the securement equipment most often utilized include the time required to secure mobility devices and inadequate securement, especially in relation to 3- and 4-wheeled scooters. In fact, 56 percent of respondents reported that mobility device securement requires from three minutes to more than five minutes to complete, suggesting that the time required to secure mobility devices may negatively affect on-time performance. However, many agencies appear to be satisfied with the securement equipment used most often in their vehicles, as a full 22 percent of respondents reported no disadvantages associated with the securement equipment installed in agency vehicles.

Survey respondents also reported difficulties associated with securing both non-common and common wheelchairs on transit vehicles. Sixty-three percent of survey respondents report that some of their passengers use non-common wheelchairs. Oversized mobility devices and scooters were most commonly reported as examples of non-common wheelchairs used by passengers. The prevalence of respondents assigning 3- and 4-wheeled scooters to the category of a non-common wheelchair provides confirmation that policy clarification is still needed from FTA, in regard to both the classification and securement of these mobility devices, as these devices typically do meet the height and weight dimensions of a "common wheelchair" provided in the ADA. Similarly, 3- and 4-wheeled "scooters" were also identified many survey respondents as the most problematic type of common wheelchair used by passengers. Specific problems noted in regard to securing scooters included the limited availability of securement points, the unstable nature of these mobility devices, especially when used as a seat on a moving vehicle, and the fact that the manufacturers of securement equipment rarely provide any guidance related to securing 3- and 4-wheeled scooters on transit vehicles.

Overall, the comments received from survey respondents indicate that agencies are doing their best to secure all types of mobility devices used by passengers, whether they meet the definition of a common wheelchair or not. In a majority of the responses, agency representatives indicated that all mobility devices are secured "to the best ability." While some agencies did report denying trips to passengers who use mobility devices that do not meet the ADA definition of a common wheelchair, the survey respondents offered many alternative securement strategies. The most common securement strategy reported in regard to noncommon wheelchairs was referring passengers who use such devices to paratransit providers. 
Agencies also reported requesting a different vehicle from dispatch and having the passenger transfer to a common wheelchair provided by the transportation provider. The survey respondents reported similar strategies in relation to accommodating common wheelchairs that are difficult to secure (i.e., 3- and 4-wheeled scooters). Additional strategies suggested for securing these common wheelchairs includes requesting that the passenger transfer to a vehicle seat during transport, the use of chair marking programs wherein passengers provide direction on the optimal securement locations on their mobility devices, and additional driver training.

Finally, agencies appear to be dealing with a number of securement-related complaints. According to survey respondents, the most common complaint from passengers and drivers alike is related to passengers who do not want their mobility device to be secured on transit vehicles. In addition, both vehicle operators and passengers who use mobility devices commonly complain about malfunctioning securement equipment. This finding is particularly significant as respondents also indicate that a majority of securement-related passenger injuries have resulted from either malfunctioning securement equipment or improper securement. In addition, several agencies reported that securement-related passenger injuries have also resulted from the use of unstable mobility devices (i.e., 3- and 4-wheeled scooters) as seats on moving transit vehicles.

The discussion of the findings presented herein provide confirmation that the securement concerns or issues described in the introductory sections of this report are, in fact, still prevalent and growing in scope. Of particular concern to transit providers is the increased use of mobility devices that, while meeting the definition of a common wheelchair, are difficult to secure on transit vehicles using ADA-compliant securement equipment. Public transportation providers are challenged to locate and install securement equipment that is ADA-compliant, can accommodate a wide and ever growing variety of mobility devices, assures at least a sufficient measure of safety to all passengers, and will not harm the mobility devices used by passengers. In order to clarify the number and types of securement that are currently available for use on public transportation vehicles in the United States, as well as the specific characteristics of such equipment, CUTR collected information on available securement device equipment from vendors and manufacturers. This information was compiled in an inventory of securement equipment and is presented and discussed in the next section of the report. 


\section{Section Two: Inventory of Wheelchair Securement Devices}

\section{Introduction}

As noted in the survey analysis presented in the previous section of this report, one of the most common challenges reported by transit and paratransit agencies represented in the Securement Device Options and Strategies Survey was locating securement equipment that can effectively secure the wide variety of mobility devices utilized by passengers (especially 3- and 4-wheeled scooters). Further, many survey respondents noted unfamiliarity with several types of securement devices listed in the survey questionnaire. In some ways, this finding is not particularly unusual; several of the listed wheelchair securement devices are not commonly used (e.g., docking systems) or are no longer available (e.g., fender brackets). However, in an effort to identify the range of securement equipment available to transit and paratransit agencies in the United States, as well as to provide clarification related to the characteristics of specific securement devices and their compatibility with the various types of mobility aid devices in use, CUTR developed an inventory of available securement devices.

A review of the Wheelchair Securement Device Inventory will reveal that a majority of the information collected pertains to tie-down/belt systems. This is not surprising, given that survey responses indicate that tie-down/belt systems are the most popular and commonly used wheelchair securement devices among paratransit and transit providers. However, discussions with manufacturers and vendors also reveal that many variations exist within available tiedown/belt systems, such as whether straps automatically adjust or must be manually adjusted and compliance with various safety standards. An additional securement-related concern expressed by public transportation providers is the issue of securement equipment compatibility with three- and four-wheel scooters. The Wheelchair Securement Device Inventory included in Table 30 attempts to address this concern, and others, in order to assist transit and paratransit providers with the decisions they must make regarding the selection of wheelchair securement equipment.

It should also be noted that many participants in the Securement Device Options and Strategies Survey reported that their agencies use wheel-lock devices to secure mobility devices on transit 
vehicles. Given that the sole use of wheel-lock devices is prohibited under the ADA securement requirements, it is likely that these agencies are using these devices in conjunction with tiedown/belt wheelchair securement systems. However, CUTR was unable to locate any vendors that distribute wheel-lock devices to individual transit properties. Therefore, the inventory contained in Table 30 does not include any information related to wheel-lock securement devices.

\section{Methodology}

The development of the Wheelchair Securement Device Inventory involved identifying potential vendors of wheelchair securement equipment. The resources utilized for this task were the Internet, industry publications, and industry contacts knowledgeable about the field of wheelchair securement. The review yielded information about several vendors and manufacturers that offer a variety of mobility device securement equipment. As stated previously, a majority of these vendors and manufacturers deal exclusively with tie-down/belt securement systems. Wheel lock systems and docking devices are considerably less widely available than tie-down/belt systems; however, information on these devices is also provided in the inventory, when available.

Following the identification of potential wheelchair securement vendors and manufacturers, a questionnaire was created and distributed to each agency by facsimile. The questionnaire was designed to gather information regarding the various series and models of securement devices distributed by the companies, as well as other descriptive characteristics of the securement devices/equipment. Specifically, the vendors and manufacturers were asked to supply information regarding the types of devices that are available, the types of mobility devices able to be effectively secured by the equipment, associated costs, and required vehicle specifications. The costs of the equipment provided by vendors and manufacturers are estimates only.

As the results of the Securement Device Options and Strategies Survey were becoming available, it was obvious that identifying a securement device that is compatible with three- and four- wheel scooters is a goal of many of the transit and paratransit agencies that participated 
in the survey. In response to this concern, additional follow-up questions were posed to the vendors and manufacturers regarding the compatibility of available securement devices with three- and four-wheel scooters. Also, recommendations were obtained from each vendor concerning the best method for securing scooters. The follow-up questions were posed through personal telephone conversations, which also provided an opportunity to clarify answers to questions in the original questionnaire. A copy of the questionnaire, including the follow-up questions, is provided in Appendix B.

\section{Vendors and Manufacturers}

As described previously, a number of sources were utilized to develop a preliminary list of vendors and manufacturers of wheelchair securement equipment. Early on, two vendors from the potential list were eliminated when it was discovered that they only manufacture mobility devices or accessibility accessories other than securement devices, such as wheelchair lifts. Additional vendors were eliminated because they sell securement devices that are designed for use in personal vehicles and not for use in public transportation vehicles. Finally, incomplete information is provided for two companies, as the project team was unable to obtain specific information from these vendors/manufacturers, despite numerous attempts. The final inventory of wheelchair securement devices includes 10 vendors and/or manufacturers. Eight of the 10 companies manufacture and/or distribute tie-down/belt securement systems. Two of the remaining companies, Latchlok and EZ-Lock, manufacture wheelchair docking systems.

\section{Wheelchair Securement Device Inventory General Findings}

As noted in previously, most of the vendors or manufacturers included in the Wheelchair Securement Device Inventory distribute tie-down or belt securement equipment. Four of the ten vendors or manufacturers (Ancra, Kinedyne, Orthosafe, and Q'Straint) distribute several variations or models of their securement devices, differing in terms of strength, technical makeup, and costs. The result is over 50 models of tie-down/belt securement systems. As shown in Table 30, these systems are available with adjustable or retractable tie-down belts. Retractable belts, which automatically retract into protective casing to prevent damage or wear caused by foot and mobility device traffic and allow for rapid adjustment upon attachment to 
mobility devices, represent one of the latest developments in wheelchair securement equipment. These tie-down systems are both more convenient and more expensive than manually adjustable tie-down belt systems. While four-point tie-down/belt systems are the most widely available and widely considered to be the safest method of wheelchair securement, at least two vendors/manufacturers offer two-point tie-down/belt securement systems.

Two companies manufacture and distribute wheelchair docking securement systems. This type of securement system requires that a docking system interface is mounted to the mobility device. The securement device is engaged once the wheelchair-mounted interface equipment connects to the securement base lock. Although research is being conducted on the applicability of this type of securement system on public transportation vehicles, it is currently considered prohibitive due to the requirement that a docking system interface must be mounted on each mobility device utilized by passengers prior to using the public transportation system. Currently, the EZ-Lock docking system is primarily intended for personal vehicles and the Latchlok docking system cannot be used with scooters.

As discussed previously, three- and four-wheel scooters present a significant securement challenge for public transportation providers. Despite this significant challenge, only three of the vendors indicated that they had a securement device or model that is considered compatible for use with scooters. However, those vendors also recommended that additional parts or supplemental securement devices be used in conjunction with the tie-down/belt equipment when securing scooters with these devices or models. However, none of the vendors/manufacturers recommended using secured scooters as seats on a moving vehicle. Rather, it was consistently recommended that passengers be asked to transfer to a vehicle seat, rather than remaining seated in the secured scooter. As described previously, neither of the vendors of docking systems recommended their use with scooters.

Additional detailed information related to the specific characteristics and uses of available wheelchair securement devices is included in the Wheelchair Securement Device Inventory provided in Table 30. The specific type of information included in each column of the inventory matrix is described in the following section. 


\section{Wheelchair Securement Device I nventory Matrix: Included Elements}

Based on the information received from the wheelchair securement equipment vendors/manufacturers, an inventory of the available securement devices was compiled into a matrix. The inventory matrix is provided in Table 30 and includes the following elements:

Vendor/Manufacturer: refers to the manufacturer or dealer of securement devices that are available for public transit vehicles.

Series: refers to a specific type or group of securement devices distributed by the vendor/manufacturer with similar characteristics regarding the device type, belt type, and safety requirements.

Model Number(s): refers to the number(s) describing a particular item or kit under a series.

Device Type: refers to the type of securement devices offered by the vendor/manufacturer, which would fall under the following categories:

Docking system: a securement device that is engaged by a wheelchair when it is rolled into a proper position allowing the wheelchair-mounted interface to connect with the securement base lock.

Four-point system: a securement device in the form of belts that attaches to the wheelchair frame and anchors to tracks in the vehicle floor at four separate points.

Two-point system: a securement device in the form of belts that attaches to the wheelchair frame and anchors to the vehicle at two separate points. Often a wheel-lock device is used to secure the rear wheels of a mobility device when the two-point system is used to secure the front of the device.

\section{Wheelchair Standards:}

$30 \mathrm{mph} / 20 \mathrm{G} \mathrm{Impact} \mathrm{Test:} \mathrm{refers} \mathrm{to} \mathrm{a} \mathrm{general} \mathrm{crash} \mathrm{test} \mathrm{requirement} \mathrm{of} \mathrm{an} \mathrm{impact} \mathrm{at}$ $30 \mathrm{mph}$ with a deceleration of 20 times gravity. This test involves using a $187 \mathrm{lb}$ surrogate wheelchair occupied by a $168 \mathrm{lb}$ dummy, or $50^{\text {th }}$ percentile male (1). This 
requirement is used extensively in wheelchair and other vehicle requirements such as the Federal Motor Vehicle Safety Standards (FMVSS), the International Standards Organization (ISO), and the Society of Automotive Engineers (SAE).

SAE 12249 requirements: refers to the Society of Automotive Engineers designated safety requirements for wheelchair tie-down and occupant restraints. These requirements include specific wheelchair design criteria, specific placing of belts in the device and on the human body both relative to the wheelchair and vehicle, material specifications, and the $30 \mathrm{MPH} / 20 \mathrm{G}$ crash test criteria (2).

ISO 10542 requirements: refers to the International Standards Organizations rules and criteria for wheelchair occupant restraints. It is based on those specified by SAE J2249 (2).

(For) Belt/Tie-Down Systems: information in this section applies to only those vendors or manufacturers of tie-down/belt systems.

Belts -- Retractable or Adjustable: identifies whether the belt system design is manually adjustable or automatically retractable. Each type of belt is described below:

Manually adjustable: describes belts that can be adjusted manually to modify tensioning.

Automatically retractable: describes belts that automatically adjust by a positive self-locking mechanism that can withstand restraint forces.

Is Mounting Hardware included: refers to whether mounting hardware (i.e. tracks or brackets) is sold as part of the securement device kit or they are sold independently.

Number of belts: refers to how many belts the securement system contains excluding lap and shoulder belts, usually two or four depending on the device type. Only those vendors of tie-down/belt systems provided this information.

Device Cost: refers to the estimated dealer or customer costs associated with purchasing the securement device and other necessary hardware (if sold independently). 
What is included in cost: indicates which necessary parts of the device (i.e. mounting hardware, belts) are included in the cost. Also notes when installation is included in the cost.

Does the cost include training: indicates whether the cost of the securement device includes training, manuals, or informational material. Many respondents noted that various types of training are available to dealers or customers, but at additional costs.

What type of training is available: refers to the types of training options or information that may be available (regardless of the costs associated with the training) to the customer.

What are the applicable vehicle specifications: refers specifically to Federal Motor Vehicle Safety Standards (FMVSS) 209, 222, 210, and 302. Each of the standards is briefly described below:

Standard No. 209: specifies requirements for seat belt assemblies including requirements applying to straps, webbing, or similar material, buckles, other fasteners, and all hardware for installing in a motor vehicle, the installation, usage, and maintenance.

Standard No. 210: establishes requirements for seat belt assembly anchorages that ensure proper location for effective occupant restraint and reduce the likelihood of failure. The requirements also apply to any component other than the webbing or straps, that is key to transferring seat belt loads to the vehicle structure.

Standard No. 222: establishes occupant protection requirements for school bus passenger seating and restraining barriers. This standard is designed to reduce the number of deaths and the severity of injuries from the impact of school bus occupants against structures within the vehicle during crashes and sudden driving maneuvers.

Standard No. 302: specifies burn resistance requirements for materials used in the occupant compartments of motor vehicles in order to reduce deaths and injuries to 
occupants caused by vehicle fires, especially those originating in the interior of the vehicle.

Average Senvice Span of System: refers to the estimated life of the system. Several vendors/manufacturers of tie-down/belt systems noted that securement belts might be worn out prior to the remaining components of the securement device and can be replaced before the end of the estimated life of the entire system.

Recommended Position for securing mobility device: this question refers to the orientation and positioning of the wheelchairs in the transit vehicle. Most ADA and other SAE or ISO requirements specify forward facing in all vehicles for wheelchairs in the securement devices.

Compatible Mobility Aid Devices; refers to which types of mobility devices are compatible with the securement equipment under each series. The responses were aligned with the types of mobility devices that survey participants said that their passengers used -- manual or power wheelchairs and three- or four-wheel scooters.

Is this system recommended for use with 3-wheel and/ or 4-wheel scooters refers to whether or not the vendor or manufacturer recommends the use of the securement device with 3- and 4-wheel scooters.

How are scooters secured: refers to the manufacturer's suggested method for best securing a scooter.

Can or should a scooter be used as a seat in a moving vehicle: refers to the manufacturer's recommendation on whether the wheelchair occupant should remain seated in the scooter or should be asked to transfer to a vehicle seat while traveling in the vehicle.

Do you inform customers (i.e. transit agencies) about scooter compatibility issues: refers to how the customer/dealer is informed of the issues with usage of the vendor's securement device if the scooter is not recommended for use or if there are stipulations on the 
use of scooters with the securement device. Methods for informing customers/dealers may include written information in manuals or informational pamphlets, and dealer/vendor communication with any possible customers. 
Table 30

Wheelchair Securement Device I nventory

\begin{tabular}{|c|c|c|c|c|c|c|c|c|c|}
\hline \multirow[b]{2}{*}{ Vendor } & \multirow[b]{2}{*}{ Series } & \multirow[b]{2}{*}{ Model Number(s) } & \multirow[b]{2}{*}{ Device Type } & \multicolumn{3}{|c|}{ Wheelchair Standards } & \multicolumn{3}{|c|}{ For Tie-Down/Belt Systems: } \\
\hline & & & & $\begin{array}{l}30 \text { mph / } 20 \text { G } \\
\text { Impact Test }\end{array}$ & $\begin{array}{c}\text { SAE J2249 } \\
\text { req's }\end{array}$ & $\begin{array}{l}\text { ISO } \\
10542 \\
\text { req's }\end{array}$ & $\begin{array}{c}\text { Belts } \\
\text { Retractable } \\
\text { or } \\
\text { Adjustable? }\end{array}$ & $\begin{array}{l}\text { Is Mounting } \\
\text { Hardware } \\
\text { included? }\end{array}$ & $\begin{array}{l}\text { Number } \\
\text { of belts }\end{array}$ \\
\hline Q'Straint & $\begin{array}{l}\text { QRT } \\
\text { Retractable } \\
\text { Securement } \\
\text { System } \\
\end{array}$ & $\begin{array}{l}\text { Q-8100-A1; Q-8200-A1; } \\
\text { Kits w/o tracks: Q-8001; } \\
\text { Q-8005; Q-8010) }\end{array}$ & 4-pt tie-down & Yes & Yes & Yes & Retractable & Yes & 4 \\
\hline Q'Straint & $\begin{array}{l}\text { Q-5001 Pocket } \\
\text { System }\end{array}$ & $\begin{array}{l}\text { Q-5001; Q-57570-A; Q- } \\
57560\end{array}$ & 4-pt tie-down & Yes & Yes & Yes & Adjustable & Yes & 4 \\
\hline Q'Straint & $\begin{array}{l}\text { Q-5001-T } \\
\text { Track System }\end{array}$ & Q-5001-T & 4-pt tie-down & Yes & Yes & Yes & Adjustable & Yes & 4 \\
\hline Q'Straint & M Series & $\begin{array}{l}\text { M-201-A; M-201-A30; } \\
\text { M-201-L; M-201-L30 }\end{array}$ & 4-pt tie-down & Yes & No & No & Adjustable & Yes & 4 \\
\hline Q'Straint & Tri-Wheeler Kit & $\begin{array}{l}\text { Q5-5010 Kit: includes } \\
\text { Q5-6114 center belt \& } \\
\text { Q5-7560-5A-extra floor } \\
\text { pocket }\end{array}$ & $\begin{array}{l}\text { (in addition to } \\
\text { 4-pt tie-down } \\
\text { systems) }\end{array}$ & Yes & Yes & Yes & Adjustable & $\begin{array}{c}\text { Not } \\
\text { Applicable }\end{array}$ & 1 \\
\hline $\begin{array}{l}\text { Kinedyne-Sure } \\
\text { Lok }\end{array}$ & $\begin{array}{l}\text { Retrakter } \\
\text { Series }\end{array}$ & $\begin{array}{l}\text { FF612; FF612S; FF627; } \\
\text { FF627S; FF612-4C; } \\
\text { FF612S-4C; FF615; } \\
\text { FF615S; FF628; } \\
\text { FF628S; FF610S; } \\
\text { FF610; FF611; FF611S }\end{array}$ & 4-pt tie-down & Yes & Yes & Yes & Retractable & No & 4 \\
\hline
\end{tabular}




\begin{tabular}{|c|c|c|c|c|c|c|c|c|c|}
\hline \multirow[b]{2}{*}{ Vendor } & \multirow[b]{2}{*}{ Series } & \multirow[b]{2}{*}{ Model Number(s) } & \multirow[b]{2}{*}{ Device Type } & \multicolumn{3}{|c|}{ Wheelchair Standards } & \multicolumn{3}{|c|}{ For Tie-Down/Belt Systems: } \\
\hline & & & & $\begin{array}{l}30 \mathrm{mph} / 20 \mathrm{G} \\
\text { Impact Test }\end{array}$ & $\begin{array}{c}\text { SAE J2249 } \\
\text { req's }\end{array}$ & \begin{tabular}{|l} 
ISO \\
10542 \\
req's
\end{tabular} & $\begin{array}{c}\text { Belts } \\
\text { Retractable } \\
\text { or } \\
\text { Adjustable? }\end{array}$ & $\begin{array}{l}\text { Is Mounting } \\
\text { Hardware } \\
\text { included? }\end{array}$ & $\begin{array}{l}\text { Number } \\
\text { of belts }\end{array}$ \\
\hline $\begin{array}{l}\text { Kinedyne-Sure } \\
\text { Lok }\end{array}$ & FE 500 Series & $\begin{array}{l}\text { FE501; FE501S; } \\
\text { FE510; FE510S; } \\
\text { FE520; FE520S; } \\
\text { FE521; FE521S; } \\
\text { FE514; FE514S; } \\
\text { FE517; FE517S; } \\
\text { FE522; FE522S; } \\
\text { FE523; FE523S } \\
\end{array}$ & 4-pt tie-down & Yes & Yes & Yes & Adjustable & No & 4 \\
\hline $\begin{array}{l}\text { Kinedyne-Sure } \\
\text { Lok }\end{array}$ & FF 800 Series & $\begin{array}{l}\text { FF865; FF865S; FF886; } \\
\text { FF886S; FF875; } \\
\text { FF875S; FF887; } \\
\text { FF887S }\end{array}$ & 4-pt tie-down & Yes & Yes & Yes & Adjustable & No & 4 \\
\hline EZ-Lock & BL6290 & BL6290 & $\begin{array}{l}\text { Automatic } \\
\text { Electric Tie- } \\
\text { down } \\
\text { (docking } \\
\text { interface) } \\
\end{array}$ & Yes & No & No & $\begin{array}{l}\text { Not } \\
\text { applicable }\end{array}$ & $\begin{array}{l}\text { System has } \\
\text { two parts } \\
\text { (includes } \\
\text { bracket for } \\
\text { wheelchair) } \\
\end{array}$ & $\begin{array}{c}\text { Not } \\
\text { applicable }\end{array}$ \\
\hline Ancra & $\begin{array}{l}48057 \text { Series } \\
\text { (Complete } \\
30 / 20 \text { kits) }\end{array}$ & $\begin{array}{l}\text { Series A: 48057-10; } \\
\text { 48057-12 (with } \\
\text { Retractor); Narrow } \\
\text { Track: 48057-11; } \\
\text { 48057-13 (with } \\
\text { Retractor); Securement } \\
\text { Kits: 47968-11; 48323- } \\
11 ; 47968-10 ; 4823-10 ; \\
47976-14 ; 47976-11 ; \\
\text { 47968-10; 48323-10 }\end{array}$ & 4-pt tie-down & Yes & Yes & No & Adjustable & $\begin{array}{l}\text { Track kit is } \\
\text { sold } \\
\text { separately }\end{array}$ & 4 \\
\hline
\end{tabular}




\begin{tabular}{|c|c|c|c|c|c|c|c|c|c|}
\hline \multirow[b]{2}{*}{ Vendor } & \multirow[b]{2}{*}{ Series } & \multirow[b]{2}{*}{ Model Number(s) } & \multirow[b]{2}{*}{ Device Type } & \multicolumn{3}{|c|}{ Wheelchair Standards } & \multicolumn{3}{|c|}{ For Tie-Down/Belt Systems: } \\
\hline & & & & $\begin{array}{c}30 \mathrm{mph} / 20 \mathrm{G} \\
\text { Impact Test }\end{array}$ & $\begin{array}{c}\text { SAE J2249 } \\
\text { req's }\end{array}$ & $\begin{array}{l}\text { ISO } \\
10542 \\
\text { req's }\end{array}$ & $\begin{array}{c}\text { Belts } \\
\text { Retractable } \\
\text { or } \\
\text { Adjustable? }\end{array}$ & $\begin{array}{l}\text { Is Mounting } \\
\text { Hardware } \\
\text { included? }\end{array}$ & $\begin{array}{l}\text { Number } \\
\text { of belts }\end{array}$ \\
\hline Ancra & 2500 Series & $\begin{array}{l}\text { Securement Kits: } \\
\text { 43866-16; 43868-18 }\end{array}$ & 4-pt tie-down & No & No & No & Adjustable & $\begin{array}{c}\text { No lap or } \\
\text { shoulder belt } \\
\text { included/ } \\
\text { track kit is } \\
\text { sold } \\
\text { separately }\end{array}$ & 4 \\
\hline Ancra & $\begin{array}{l}\text { Retractable } \\
\text { Chair Tie- } \\
\text { Down Strap } \\
\end{array}$ & $48846-10$ & 2-pt tie-down & No & No & No & Retractable & No & 2 \\
\hline Ancra & $\begin{array}{l}\text { Retractable } \\
\text { Strap for 3- } \\
\text { wheel scooter }\end{array}$ & $48780-10$ & $\begin{array}{l}\text { 4-pt tie-down } \\
\text { (in } \\
\text { conjunction } \\
\text { w/ 48846-10) }\end{array}$ & No & No & No & Retractable & No & 2 \\
\hline $\begin{array}{l}\text { American } \\
\text { Seating } \\
\text { Company }\end{array}$ & $\begin{array}{l}\text { ARM System } \\
\text { (advanced } \\
\text { Restraint } \\
\text { Module) } \\
\end{array}$ & $\begin{array}{l}\text { ARM (one system } \\
\text { includes belts from } \\
\text { Q'Straint) front ARM w/ } \\
2 \text { belts and a back } \\
\text { barrier or a flip up seat } \\
\text { with } 4 \text { belts ( } 2 \\
\text { securement belts, } 2 \\
\text { lap/shoulder) }\end{array}$ & 4-pt tie-down & \begin{tabular}{|c|} 
only a \\
recommendation \\
in SAE J2249
\end{tabular} & $\begin{array}{c}\text { Yes, except } \\
\text { for } \\
30 \mathrm{mph} / 20 \mathrm{G}\end{array}$ & No & Retractable & No & 4 \\
\hline \begin{tabular}{|l} 
Beam's \\
Industries Inc.
\end{tabular} & $\begin{array}{l}\text { Customized } \\
\text { Tie-downs }\end{array}$ & $\begin{array}{l}\text { Manual \& Adjustable } \\
\text { Series (Customized) }\end{array}$ & 4-pt tie-down & Some & No & No & Both & No & 4 \\
\hline $\begin{array}{l}\text { Beam's } \\
\text { Industries Inc. }\end{array}$ & $\begin{array}{l}\text { Customized } \\
\text { Tie-downs }\end{array}$ & $\begin{array}{l}\text { Manual \& Adjustable } \\
\text { Series (Customized) }\end{array}$ & $\begin{array}{l}2 \text { or } 4 \text {-pt tie- } \\
\text { down }\end{array}$ & Some & No & No & Both & No & 2 \\
\hline
\end{tabular}




\begin{tabular}{|c|c|c|c|c|c|c|c|c|c|}
\hline \multirow[b]{2}{*}{ Vendor } & \multirow[b]{2}{*}{ Series } & \multirow[b]{2}{*}{ Model Number(s) } & \multirow[b]{2}{*}{ Device Type } & \multicolumn{3}{|c|}{ Wheelchair Standards } & \multicolumn{3}{|c|}{ For Tie-Down/Belt Systems: } \\
\hline & & & & $\begin{array}{l}30 \mathrm{mph} / 20 \mathrm{G} \\
\text { Impact Test }\end{array}$ & $\begin{array}{c}\text { SAE J2249 } \\
\text { req's }\end{array}$ & $\begin{array}{l}\text { ISO } \\
10542 \\
\text { req's }\end{array}$ & $\begin{array}{c}\text { Belts } \\
\text { Retractable } \\
\text { or } \\
\text { Adjustable? }\end{array}$ & $\begin{array}{l}\text { Is Mounting } \\
\text { Hardware } \\
\text { included? }\end{array}$ & $\begin{array}{l}\text { Number } \\
\text { of belts }\end{array}$ \\
\hline $\begin{array}{l}\text { Ortho Safe } \\
\text { Systems }\end{array}$ & $\begin{array}{l}\text { Quick Connec } \\
\text { Retractor } \\
\text { Series } 2001\end{array}$ & & 4-pt tie-down & & Yes & Yes & Retractable & Yes & 4 \\
\hline $\begin{array}{l}\text { Ortho Safe } \\
\text { Systems }\end{array}$ & Series 1 & $50-00$ & 4-pt tie-down & & Yes & Yes & $\begin{array}{l}\text { Front } \\
\text { Retractable/ } \\
\text { Rear Static }\end{array}$ & Yes & 4 \\
\hline $\begin{array}{l}\text { Ortho Safe } \\
\text { Systems }\end{array}$ & Series 2 & OS - $17260-04$ & 4-pt tie-down & & Yes & Yes & Retractable & Yes & 4 \\
\hline $\begin{array}{l}\text { Ortho Safe } \\
\text { Systems }\end{array}$ & Series 3 & BB - 1726405 & 4-pt tie-down & & Yes & Yes & Retractable & Yes & 4 \\
\hline $\begin{array}{l}\text { Ortho Safe } \\
\text { Systems }\end{array}$ & Series 4 & BB - 1726413 & 4-pt tie-down & & Yes & Yes & Static & Yes & 4 \\
\hline Latchlok & $\begin{array}{l}\text { Automatic } \\
\text { Power } \\
\text { Wheelchair } \\
\text { Tie-Down } \\
\end{array}$ & $\begin{array}{l}\text { WT_LLFM_AC, } \\
\text { WT_LLCM_AC }\end{array}$ & $\begin{array}{l}\text { Power } \\
\text { Docking } \\
\text { System }\end{array}$ & Yes & No & No & $\begin{array}{l}\text { Not } \\
\text { Applicable }\end{array}$ & $\begin{array}{l}\text { System has } \\
\text { two parts } \\
\text { (includes } \\
\text { bracket for } \\
\text { wheelchair) }\end{array}$ & $\begin{array}{c}\text { Not } \\
\text { Applicable }\end{array}$ \\
\hline
\end{tabular}




\begin{tabular}{|c|c|c|c|c|c|c|c|}
\hline Vendor & Series & Model Number(s) & $\begin{array}{l}\text { Device } \\
\text { Average } \\
\text { Cost? }\end{array}$ & $\begin{array}{l}\text { What is } \\
\text { included in } \\
\text { cost? }\end{array}$ & $\begin{array}{l}\text { Does the cost } \\
\text { include training? }\end{array}$ & $\begin{array}{l}\text { What type of } \\
\text { training is } \\
\text { available? }\end{array}$ & $\begin{array}{l}\text { Applicable } \\
\text { vehicle } \\
\text { specifications }\end{array}$ \\
\hline Q'Straint & $\begin{array}{l}\text { QRT } \\
\text { Retractable } \\
\text { Securement } \\
\text { System } \\
\end{array}$ & $\begin{array}{l}\text { Q-8100-A1; Q-8200-A1; Kits } \\
\text { w/o tracks: Q-8001; Q-8005; } \\
\text { Q-8010) }\end{array}$ & $\$ 435.50$ & $\begin{array}{l}\text { Must purchase } \\
\text { pockets } \\
\text { individually }\end{array}$ & $\begin{array}{l}\text { No charge for video, } \\
\text { salesperson training } \\
\text { may be available }\end{array}$ & $\begin{array}{l}\text { Videos, training } \\
\text { area at seminars, } \\
\text { salesperson may } \\
\text { visit }\end{array}$ & $\begin{array}{l}\text { FMVSS 209, 222, } \\
210,302\end{array}$ \\
\hline Q'Straint & $\begin{array}{l}\text { Q-5001 Pocket } \\
\text { System }\end{array}$ & $\begin{array}{l}\text { Q-5001; Q-57570-A; Q- } \\
57560\end{array}$ & $\$ 376.00$ & All & $\$ 10 /$ video & $\begin{array}{l}\text { Videos, training } \\
\text { area at seminars, } \\
\text { salesperson may } \\
\text { visit }\end{array}$ & $\begin{array}{l}\text { FMVSS 209, 222, } \\
210,302\end{array}$ \\
\hline Q'Straint & $\begin{array}{l}\text { Q-5001-T Track } \\
\text { System }\end{array}$ & Q-5001-T & $\$ 315.00$ & $\begin{array}{l}\text { No track } \\
\text { included }\end{array}$ & $\$ 10 /$ video & $\begin{array}{l}\text { Videos, training } \\
\text { area at seminars, } \\
\text { salesperson may } \\
\text { visit }\end{array}$ & $\begin{array}{l}\text { FMVSS 209, 222, } \\
210,302\end{array}$ \\
\hline Q'Straint & M Series & $\begin{array}{l}\text { M-201-A; M-201-A30; M- } \\
\text { 201-L; M-201-L30 }\end{array}$ & $\$ 74.40$ & $\begin{array}{l}\text { No track } \\
\text { included, no lap } \\
\text { or shoulder belt }\end{array}$ & $\begin{array}{l}\text { Manuals and } \\
\text { installation } \\
\text { information are all } \\
\text { provided }\end{array}$ & $\begin{array}{l}\text { Videos, training } \\
\text { area at seminars, } \\
\text { salesperson may } \\
\text { visit }\end{array}$ & FMVSS 209, 302 \\
\hline Q'Straint & Tri-Wheeler Kit & $\begin{array}{l}\text { Q5-5010 Kit: includes Q5- } \\
\text { 6114 center belt \& Q5-7560- } \\
\text { 5A-extra floor pocket }\end{array}$ & $\$ 100.80$ & One belt & $\begin{array}{l}\text { Manual and } \\
\text { installation } \\
\text { instructions }\end{array}$ & $\begin{array}{l}\text { Salesperson would } \\
\text { do any onsite } \\
\text { training }\end{array}$ & FMVSS 209, 302 \\
\hline Kinedyne-Sure Lok & Retrakter Series & $\begin{array}{l}\text { FF612; FF612S; FF627; } \\
\text { FF627S; FF612-4C; } \\
\text { FF612S-4C; FF615; } \\
\text { FF615S; FF628; FF628S; } \\
\text { FF610S; FF610; FF611; } \\
\text { FF611S }\end{array}$ & $\$ 250-\$ 500$ & $\begin{array}{l}\text { Everything but } \\
\text { mounting } \\
\text { hardware (track } \\
\text { \& floor plates) }\end{array}$ & $\begin{array}{l}\text { Instruction manual } \\
\text { included free, video } \\
\text { can be ordered } \\
\text { online at a cost, } \\
\text { seminars or } \\
\text { conferences offered }\end{array}$ & $\begin{array}{l}\text { Video, pamphlets } \\
\text { instructional, "Safe } \\
\text { \& Secure" training is } \\
\text { offered at Southeast } \\
\text { and Midwest }\end{array}$ & $\begin{array}{l}\text { FMVSS 209, 222, } \\
210,302\end{array}$ \\
\hline
\end{tabular}




\begin{tabular}{|c|c|c|c|c|c|c|c|}
\hline Vendor & Series & Model Number(s) & $\begin{array}{l}\text { Device } \\
\text { Average } \\
\text { Cost? }\end{array}$ & $\begin{array}{l}\text { What is } \\
\text { included in } \\
\text { cost? }\end{array}$ & $\begin{array}{l}\text { Does the cost } \\
\text { include training? }\end{array}$ & $\begin{array}{l}\text { What type of } \\
\text { training is } \\
\text { available? }\end{array}$ & $\begin{array}{l}\text { Applicable } \\
\text { vehicle } \\
\text { specifications }\end{array}$ \\
\hline Kinedyne-Sure Lok & FE 500 Series & $\begin{array}{l}\text { FE501; FE501S; FE510; } \\
\text { FE510S; FE520; FE520S; } \\
\text { FE521; FE521S; FE514; } \\
\text { FE514S; FE517; FE517S; } \\
\text { FE522; FE522S; FE523; } \\
\text { FE523S }\end{array}$ & $\$ 65-\$ 150$ & $\begin{array}{l}\text { Everything but } \\
\text { mounting } \\
\text { hardware (track } \\
\& \text { floor plates) } \\
\end{array}$ & $\begin{array}{l}\text { Instruction manual } \\
\text { included free, video } \\
\text { can be ordered } \\
\text { online at a cost, } \\
\text { seminars or } \\
\text { conferences offered }\end{array}$ & $\begin{array}{l}\text { Video, pamphlets } \\
\text { instructional, "Safe } \\
\text { \& Secure" training is } \\
\text { offered at Southeast } \\
\text { and Midwest }\end{array}$ & $\begin{array}{l}\text { FMVSS 209, 222, } \\
210,302\end{array}$ \\
\hline Kinedyne-Sure Lok & FF 800 Series & $\begin{array}{l}\text { FF865; FF865S; FF886; } \\
\text { FF886S; FF875; FF875S; } \\
\text { FF887; FF887S }\end{array}$ & $\$ 55-\$ 100$ & $\begin{array}{l}\text { Everything but } \\
\text { mounting } \\
\text { hardware (track } \\
\text { \& floor plates) } \\
\end{array}$ & $\begin{array}{l}\text { Instruction manual } \\
\text { included free, video } \\
\text { can be ordered } \\
\text { online at a cost, } \\
\text { seminars or } \\
\text { conferences offered }\end{array}$ & $\begin{array}{l}\text { Video, pamphlets } \\
\text { instructional, "Safe } \\
\& \text { Secure" training is } \\
\text { offered at Southeast } \\
\text { and Midwest }\end{array}$ & $\begin{array}{l}\text { FMVSS 209, 222, } \\
210,302\end{array}$ \\
\hline EZ-Lock & BL6290 & BL6290 & $\begin{array}{l}\$ 1200- \\
\$ 1900\end{array}$ & $\begin{array}{l}\text { Complete } \\
\text { system installed }\end{array}$ & $\begin{array}{l}\text { Sell to dealers in } \\
\text { FL, conversion vans } \\
\text { (they do all } \\
\text { installation and } \\
\text { training) }\end{array}$ & $\begin{array}{l}\text { User instructions } \\
\text { and reference card } \\
\text { for vehicles }\end{array}$ & $\begin{array}{l}\text { FMVSS 209, 222, } \\
210,302\end{array}$ \\
\hline Ancra & $\begin{array}{l}48057 \text { Series } \\
\text { (Complete 30/20 } \\
\text { kits) }\end{array}$ & $\begin{array}{l}\text { Series A: 48057-10; 48057- } \\
12 \text { (with Retractor); Narrow } \\
\text { Track: 48057-11; 48057-13 } \\
\text { (with Retractor); } \\
\text { Securement Kits: 47968- } \\
11 ; 48323-11 ; 47968-10 ; \\
4823-10 ; 47976-14 ; 47976- \\
11 ; 47968-10 ; 48323-10\end{array}$ & $\begin{array}{l}\$ 70 \text { to a } \\
\text { dealer }\end{array}$ & $\begin{array}{l}\text { Everything but } \\
\text { mounting } \\
\text { hardware (track } \\
\& \text { floor plates) } \\
\end{array}$ & Manual provided & $\begin{array}{l}\text { As requested, sales } \\
\text { training available, } \\
\text { installation and } \\
\text { operation manual }\end{array}$ & $\begin{array}{l}\text { FMVSS 209, 222, } \\
210,302\end{array}$ \\
\hline Ancra & 2500 Series & $\begin{array}{l}\text { Securement Kits: 43866- } \\
16 ; 43868-18\end{array}$ & $\begin{array}{l}\$ 35-40 \text { to } \\
\text { dealer }\end{array}$ & $\begin{array}{l}\text { 4-point system } \\
\text { (no track, } \\
\text { lap/shoulder } \\
\text { belt) }\end{array}$ & Manual provided & $\begin{array}{l}\text { As requested, sales } \\
\text { training available, } \\
\text { installation and } \\
\text { operation manual }\end{array}$ & No \\
\hline
\end{tabular}




\begin{tabular}{|c|c|c|c|c|c|c|c|}
\hline Vendor & Series & Model Number(s) & $\begin{array}{l}\text { Device } \\
\text { Average } \\
\text { Cost? }\end{array}$ & $\begin{array}{l}\text { What is } \\
\text { included in } \\
\text { cost? }\end{array}$ & $\begin{array}{l}\text { Does the cost } \\
\text { include training? }\end{array}$ & $\begin{array}{l}\text { What type of } \\
\text { training is } \\
\text { available? }\end{array}$ & $\begin{array}{l}\text { Applicable } \\
\text { vehicle } \\
\text { specifications }\end{array}$ \\
\hline Ancra & $\begin{array}{l}\text { Retractable } \\
\text { Chair Tie-Down } \\
\text { Strap }\end{array}$ & $48846-10$ & $\begin{array}{l}\$ 25 \text { to } \\
\text { dealer } \\
(\$ 50)\end{array}$ & Only the belt & Manual provided & & No \\
\hline Ancra & $\begin{array}{l}\text { Retractable } \\
\text { Strap for 3- } \\
\text { wheel scooter }\end{array}$ & $48780-10$ & $\begin{array}{l}\$ 25 \text { to } \\
\text { dealer } \\
(\$ 50)\end{array}$ & Only the belt & Manual provided & & No \\
\hline $\begin{array}{l}\text { American Seating } \\
\text { Company }\end{array}$ & $\begin{array}{l}\text { ARM System } \\
\text { (advanced } \\
\text { Restraint } \\
\text { Module) } \\
\end{array}$ & $\begin{array}{l}\text { ARM (one system includes } \\
\text { belts from Q'Straint) front } \\
\text { ARM w/ } 2 \text { belts and a back } \\
\text { barrier or a flip up seat with } \\
4 \text { belts ( } 2 \text { securement belts, } \\
2 \text { lap/shoulder) }\end{array}$ & $\begin{array}{l}\$ 1500 \\
\text { corporate } \\
\text { list cost to } \\
\text { the builder }\end{array}$ & $\begin{array}{l}\text { Complete } \\
\text { system, but not } \\
\text { installed }\end{array}$ & $\begin{array}{l}\text { Video free of } \\
\text { charge, parts } \\
\text { manuals, video }\end{array}$ & $\begin{array}{l}\text { Salesperson would } \\
\text { do any onsite } \\
\text { training }\end{array}$ & $\begin{array}{l}\text { FMVSS 209, 210, } \\
302\end{array}$ \\
\hline $\begin{array}{l}\text { Beam's Industries } \\
\text { Inc. }\end{array}$ & $\begin{array}{l}\text { Customized Tie- } \\
\text { downs }\end{array}$ & $\begin{array}{l}\text { Manual \& Adjustable Series } \\
\text { (Customized) }\end{array}$ & $\begin{array}{l}\$ 25-55 \\
\$ 35-95\end{array}$ & Belts only & No & $\begin{array}{l}\text { A salesperson is } \\
\text { available for free, if } \\
\text { requested. }\end{array}$ & FMVSS 209 \\
\hline $\begin{array}{l}\text { Beam's Industries } \\
\text { Inc. }\end{array}$ & $\begin{array}{l}\text { Customized Tie- } \\
\text { downs }\end{array}$ & $\begin{array}{l}\text { Manual \& Adjustable Series } \\
\text { (Customized) }\end{array}$ & $\begin{array}{l}\$ 25-55 \\
\$ 35-95\end{array}$ & Belts only & No & $\begin{array}{l}\text { A salesperson is } \\
\text { available for free if } \\
\text { requested. }\end{array}$ & FMVSS 209 \\
\hline $\begin{array}{l}\text { Ortho Safe } \\
\text { Systems }\end{array}$ & $\begin{array}{l}\text { Quick Connect } \\
\text { Retractor Series } \\
2001\end{array}$ & & $\begin{array}{l}\text { Not } \\
\text { released }\end{array}$ & Not released & $\begin{array}{l}\text { Operation manual } \\
\text { only }\end{array}$ & & FMVSS 209 \\
\hline
\end{tabular}




\begin{tabular}{|c|c|c|c|c|c|c|c|}
\hline Vendor & Series & Model Number(s) & $\begin{array}{l}\text { Device } \\
\text { Average } \\
\text { Cost? }\end{array}$ & $\begin{array}{l}\text { What is } \\
\text { included in } \\
\text { cost? }\end{array}$ & $\begin{array}{c}\text { Does the cost } \\
\text { include training? }\end{array}$ & $\begin{array}{c}\text { What type of } \\
\text { training is } \\
\text { available? }\end{array}$ & $\begin{array}{c}\text { Applicable } \\
\text { vehicle } \\
\text { specifications }\end{array}$ \\
\hline $\begin{array}{l}\text { Ortho Safe } \\
\text { Systems }\end{array}$ & Series 1 & $50-00$ & $\begin{array}{l}\text { Not } \\
\text { released }\end{array}$ & Not released & $\begin{array}{l}\text { Operation manual } \\
\text { only }\end{array}$ & & FMVSS 209 \\
\hline $\begin{array}{l}\text { Ortho Safe } \\
\text { Systems }\end{array}$ & Series 2 & OS - 17260-04 & $\begin{array}{l}\text { Not } \\
\text { released }\end{array}$ & Not released & $\begin{array}{l}\text { Operation manual } \\
\text { only }\end{array}$ & & FMVSS 209 \\
\hline $\begin{array}{l}\text { Ortho Safe } \\
\text { Systems }\end{array}$ & Series 3 & BB - 1726405 & $\begin{array}{l}\text { Not } \\
\text { released }\end{array}$ & Not released & $\begin{array}{l}\text { Operation manual } \\
\text { only }\end{array}$ & & FMVSS 209 \\
\hline $\begin{array}{l}\text { Ortho Safe } \\
\text { Systems }\end{array}$ & Series 4 & BB - 1726413 & $\begin{array}{l}\text { Not } \\
\text { released }\end{array}$ & Not released & $\begin{array}{l}\text { Operation manual } \\
\text { only }\end{array}$ & & FMVSS 209 \\
\hline Latchlok & $\begin{array}{l}\text { Automatic } \\
\text { Power } \\
\text { Wheelchair Tie- } \\
\text { Down }\end{array}$ & $\begin{array}{l}\text { WT_LLFM_AC, } \\
\text { WT_LLCM_AC }\end{array}$ & $\begin{array}{l}\$ 1430 \text { or } \\
\text { more per }\end{array}$ & $\begin{array}{l}\text { Tie-down, } \\
\text { docking system, } \\
\text { latch } \\
\text { mechanism, } \\
\text { passenger } \\
\text { restraints, } \\
\text { installation }\end{array}$ & $\begin{array}{l} \\
\text { Operating } \\
\text { instructions }\end{array}$ & & \\
\hline
\end{tabular}




\begin{tabular}{|c|c|c|c|c|c|c|c|c|c|}
\hline Vendor & Series & $\begin{array}{l}\text { Average } \\
\text { Service } \\
\text { Span of } \\
\text { System }\end{array}$ & $\begin{array}{l}\text { Recommended } \\
\text { position for } \\
\text { securing } \\
\text { mobility devices }\end{array}$ & $\begin{array}{c}\text { Compatible } \\
\text { mobility aid } \\
\text { devices }\end{array}$ & $\begin{array}{l}\text { Is this system } \\
\text { recommended } \\
\text { for use with } \\
\text { scooters? }\end{array}$ & $\begin{array}{l}\text { How is the } \\
\text { scooter } \\
\text { secured? }\end{array}$ & $\begin{array}{c}\text { Can / Should a } \\
\text { scooter be } \\
\text { used as a seat } \\
\text { in a moving } \\
\text { vehicle? }\end{array}$ & $\begin{array}{l}\text { Do you inform } \\
\text { customers (I.e. } \\
\text { transit agency, } \\
\text { etc.) about } \\
\text { incompatibility } \\
\text { of scooters? }\end{array}$ & $\begin{array}{l}\text { Comments } \\
\text { on Features }\end{array}$ \\
\hline Q'Straint & $\begin{array}{l}\text { QRT } \\
\text { Retractable } \\
\text { Securement } \\
\text { System } \\
\end{array}$ & 5-10 years & Forward-facing & \begin{tabular}{|l|} 
Regular \\
wheelchairs, \\
electric \\
wheelchairs, \\
triwheelers \\
\end{tabular} & \begin{tabular}{|l} 
Do not \\
recommend \\
without extra Tri- \\
wheeler kit
\end{tabular} & See below & $\begin{array}{l}\text { Recommend } \\
\text { transfer to a } \\
\text { vehicle seat } \\
\end{array}$ & Not Applicable & \\
\hline Q'Straint & $\begin{array}{l}\text { Q-5001 } \\
\text { Pocket } \\
\text { System }\end{array}$ & $5-10$ years & Forward-facing & \begin{tabular}{|l|} 
Regular \\
wheelchairs, \\
electric \\
wheelchairs, \\
triwheelers \\
\end{tabular} & $\begin{array}{l}\text { Do not } \\
\text { recommend } \\
\text { without extra Tri- } \\
\text { wheeler kit }\end{array}$ & See below & $\begin{array}{l}\text { Recommend } \\
\text { transfer to a } \\
\text { vehicle seat }\end{array}$ & Not Applicable & \\
\hline Q'Straint & $\begin{array}{l}\text { Q-5001-T } \\
\text { Track } \\
\text { System }\end{array}$ & $5-10$ years & Forward-facing & \begin{tabular}{|l|} 
Regular \\
wheelchairs, \\
electric \\
wheelchairs, \\
triwheelers \\
\end{tabular} & \begin{tabular}{|l} 
Do not \\
recommend \\
without extra Tri- \\
wheeler kit
\end{tabular} & See below & $\begin{array}{l}\text { Recommend } \\
\text { transfer to a } \\
\text { vehicle seat } \\
\end{array}$ & Not Applicable & \\
\hline Q'Straint & M Series & 5-10 years & Forward-facing & $\begin{array}{l}\text { Regular } \\
\text { wheelchairs, } \\
\text { electric } \\
\text { wheelchairs, } \\
\text { triwheelers } \\
\end{array}$ & $\begin{array}{l}\text { Do not } \\
\text { recommend } \\
\text { without extra Tri- } \\
\text { wheeler kit }\end{array}$ & See below & $\begin{array}{l}\text { Recommend } \\
\text { transfer to a } \\
\text { vehicle seat }\end{array}$ & Not Applicable & $\begin{array}{l}\text { Only meets } \\
\text { ADA }\end{array}$ \\
\hline Q'Straint & $\begin{array}{l}\text { Tri-Wheeler } \\
\text { Kit }\end{array}$ & $5-10$ years & Forward-facing & Scooters & $\begin{array}{l}\text { Yes, with tie- } \\
\text { down system }\end{array}$ & $\begin{array}{l}\text { Secured to a } \\
\text { horizontal or } \\
\text { vertical frame } \\
\text { member, } \\
\text { position a } \\
\text { webbing loop } \\
\text { around the } \\
\text { front post, then } \\
\text { connect to tie- } \\
\text { downs }\end{array}$ & $\begin{array}{l}\text { Recommend } \\
\text { transfer to a } \\
\text { vehicle seat }\end{array}$ & $\begin{array}{l}\text { Optional } \\
\text { Installation of Tri- } \\
\text { wheeler Kit (on } \\
\text { Installation } \\
\text { requirements), } \\
\text { the salesperson } \\
\text { will usually know } \\
\text { to inform }\end{array}$ & \\
\hline
\end{tabular}




\begin{tabular}{|c|c|c|c|c|c|c|c|c|c|}
\hline Vendor & Series & $\begin{array}{l}\text { Average } \\
\text { Service } \\
\text { Span of } \\
\text { System }\end{array}$ & $\begin{array}{l}\text { Recommended } \\
\text { position for } \\
\text { securing } \\
\text { mobility devices }\end{array}$ & $\begin{array}{c}\text { Compatible } \\
\text { mobility aid } \\
\text { devices }\end{array}$ & $\begin{array}{l}\text { Is this system } \\
\text { recommended } \\
\text { for use with } \\
\text { scooters? }\end{array}$ & $\begin{array}{l}\text { How is the } \\
\text { scooter } \\
\text { secured? }\end{array}$ & $\begin{array}{l}\text { Can / Should a } \\
\text { scooter be } \\
\text { used as a seat } \\
\text { in a moving } \\
\text { vehicle? }\end{array}$ & $\begin{array}{l}\text { Do you inform } \\
\text { customers (l.e. } \\
\text { transit agency, } \\
\text { etc.) about } \\
\text { incompatibility } \\
\text { of scooters? }\end{array}$ & $\begin{array}{l}\text { Comments } \\
\text { on Features }\end{array}$ \\
\hline $\begin{array}{l}\text { Kinedyne- } \\
\text { Sure Lok }\end{array}$ & $\begin{array}{l}\text { Retrakter } \\
\text { Series }\end{array}$ & $5+$ years & Forward-facing & $\begin{array}{l}\text { Only } \\
\text { standard or } \\
\text { electric } \\
\text { wheelchairs } \\
\end{array}$ & $\begin{array}{l}\text { Do not } \\
\text { recommend use } \\
\text { with scooters }\end{array}$ & $\begin{array}{l}\text { Secured to a } \\
\text { frame } \\
\text { member, no } \\
\text { moveable } \\
\text { parts }\end{array}$ & $\begin{array}{l}\text { Recommend } \\
\text { transfer to a } \\
\text { vehicle seat }\end{array}$ & $\begin{array}{l}\text { In print in } \\
\text { catalogs, Dealers } \\
\text { are aware of } \\
\text { recommendations } \\
\text { for scooters }\end{array}$ & \\
\hline $\begin{array}{l}\text { Kinedyne- } \\
\text { Sure Lok }\end{array}$ & $\begin{array}{l}\text { FE } 500 \\
\text { Series }\end{array}$ & $5+$ years & Forward-facing & All & $\begin{array}{l}\text { Do not } \\
\text { recommend use } \\
\text { with scooters }\end{array}$ & $\begin{array}{l}\text { Secured to a } \\
\text { frame } \\
\text { member, no } \\
\text { moveable } \\
\text { parts }\end{array}$ & $\begin{array}{l}\text { Recommend } \\
\text { transfer to a } \\
\text { vehicle seat }\end{array}$ & $\begin{array}{l}\text { In print in } \\
\text { catalogs, Dealers } \\
\text { are aware of } \\
\text { recommendations } \\
\text { for scooters }\end{array}$ & \\
\hline $\begin{array}{l}\text { Kinedyne- } \\
\text { Sure Lok }\end{array}$ & $\begin{array}{l}\text { FF } 800 \\
\text { Series }\end{array}$ & $5+$ years & Forward-facing & All & $\begin{array}{l}\text { Do not } \\
\text { recommend use } \\
\text { with scooters }\end{array}$ & $\begin{array}{l}\text { Secured to a } \\
\text { frame } \\
\text { member, no } \\
\text { moveable } \\
\text { parts }\end{array}$ & $\begin{array}{l}\text { Recommend } \\
\text { transfer to a } \\
\text { vehicle seat }\end{array}$ & $\begin{array}{l}\text { In print in } \\
\text { catalogs, Dealers } \\
\text { are aware of } \\
\text { recommendations } \\
\text { for scooters }\end{array}$ & $\begin{array}{l}\text { Only meets } \\
\text { ADA }\end{array}$ \\
\hline EZ-Lock & BL6290 & 8-12 years & Forward-facing & \begin{tabular}{|l|} 
Manual \& \\
electric \\
wheelchairs \\
\end{tabular} & $\begin{array}{l}\text { No - testing has } \\
\text { not been done }\end{array}$ & Not applicable & $\begin{array}{l}\text { Recommend } \\
\text { transfer to a } \\
\text { vehicle seat } \\
\end{array}$ & Inform dealers & $\begin{array}{l}\text { Primarily for } \\
\text { personal } \\
\text { vehicles } \\
\end{array}$ \\
\hline Ancra & \begin{tabular}{|l}
48057 \\
Series \\
(Complete \\
$30 / 20$ kits)
\end{tabular} & 2-3 years & Forward-facing & \begin{tabular}{|l} 
Manual \& \\
electric \\
wheelchairs
\end{tabular} & No & Not applicable & $\begin{array}{l}\text { Recommend } \\
\text { transfer to a } \\
\text { vehicle seat }\end{array}$ & \begin{tabular}{|l|} 
"What to Do" \\
operation and \\
maintenance \\
bulletin that goes \\
with this kit
\end{tabular} & $\begin{array}{l}30 \mathrm{mph} / 20 \mathrm{G} \\
\text { impact test }\end{array}$ \\
\hline
\end{tabular}




\begin{tabular}{|c|c|c|c|c|c|c|c|c|c|}
\hline Vendor & Series & $\begin{array}{l}\text { Average } \\
\text { Service } \\
\text { Span of } \\
\text { System }\end{array}$ & $\begin{array}{l}\text { Recommended } \\
\text { position for } \\
\text { securing } \\
\text { mobility devices }\end{array}$ & $\begin{array}{c}\text { Compatible } \\
\text { mobility aid } \\
\text { devices }\end{array}$ & $\begin{array}{l}\text { Is this system } \\
\text { recommended } \\
\text { for use with } \\
\text { scooters? }\end{array}$ & $\begin{array}{l}\text { How is the } \\
\text { scooter } \\
\text { secured? }\end{array}$ & $\begin{array}{l}\text { Can / Should a } \\
\text { scooter be } \\
\text { used as a seat } \\
\text { in a moving } \\
\text { vehicle? }\end{array}$ & $\begin{array}{l}\text { Do you inform } \\
\text { customers (I.e. } \\
\text { transit agency, } \\
\text { etc.) about } \\
\text { incompatibility } \\
\text { of scooters? }\end{array}$ & $\begin{array}{l}\text { Comments } \\
\text { on Features }\end{array}$ \\
\hline Ancra & 2500 Series & 2-3 years & Forward-facing & \begin{tabular}{|l|} 
Manual \& \\
electric \\
wheelchairs \\
\end{tabular} & No & Not applicable & $\begin{array}{l}\text { Recommend } \\
\text { transfer to a } \\
\text { vehicle seat } \\
\end{array}$ & $\begin{array}{l}\text { Operation and } \\
\text { maintenance } \\
\text { bulletin that goes } \\
\text { with this kit }\end{array}$ & $\begin{array}{l}\text { Never crash } \\
\text { tested }\end{array}$ \\
\hline Ancra & $\begin{array}{l}\text { Retractable } \\
\text { Chair Tie- } \\
\text { Down Strap }\end{array}$ & 2-3 years & Forward-facing & $\begin{array}{l}\text { Manual \& } \\
\text { electric } \\
\text { wheelchairs }\end{array}$ & $\begin{array}{l}\text { Only with } \\
\text { additional } \\
\text { scooter strap } \\
\text { (see below) }\end{array}$ & See below & $\begin{array}{l}\text { Recommend } \\
\text { transfer to a } \\
\text { vehicle seat }\end{array}$ & $\begin{array}{l}\text { operation and } \\
\text { maintenance } \\
\text { bulletin that goes } \\
\text { with this kit }\end{array}$ & $\begin{array}{l}\text { Used in } \\
\text { conjunction } \\
\text { with 2-pt } \\
\text { retractable } \\
\text { chair tie-down } \\
\text { straps }\end{array}$ \\
\hline Ancra & $\begin{array}{l}\text { Retractable } \\
\text { Strap for 3- } \\
\text { wheel } \\
\text { scooter }\end{array}$ & 2-3 years & Forward-facing & $\begin{array}{l}\text { Specifically } \\
\text { for scooters }\end{array}$ & $\begin{array}{l}\text { Yes, when used } \\
\text { with 2-point tie- } \\
\text { down system }\end{array}$ & $\begin{array}{l}\text { Scooter strap } \\
\text { is wrapped } \\
\text { around post } \\
\text { and back to a } \\
\text { floor tie-down } \\
\text { post }\end{array}$ & $\begin{array}{l}\text { Recommend } \\
\text { transfer to a } \\
\text { vehicle seat }\end{array}$ & $\begin{array}{l}\text { Specifically } \\
\text { designed for } \\
\text { scooters, } \\
\text { operation and } \\
\text { maintenance } \\
\text { bulletin that goes } \\
\text { with this kit }\end{array}$ & \\
\hline $\begin{array}{l}\text { American } \\
\text { Seating } \\
\text { Company }\end{array}$ & $\begin{array}{l}\text { ARM } \\
\text { System } \\
\text { (advanced } \\
\text { Restraint } \\
\text { Module) } \\
\end{array}$ & $\begin{array}{l}\text { Designed } \\
\text { for heavy } \\
\text { duty buses } \\
\text { (life of the } \\
\text { bus) -belts } \\
\text { are subject } \\
\text { to Q'Straint } \\
\text { and Indiana } \\
\text { Mills) } \\
\end{array}$ & Forward-facing & $\begin{array}{l}\text { ADA } \\
\text { definition of } \\
\text { wheelchair } \\
\text { (scooters, } \\
\text { electric) } \\
\end{array}$ & $\begin{array}{l}\text { Depends on the } \\
\text { scooter }\end{array}$ & $\begin{array}{l}\text { Back arm } \\
\text { supports are } \\
\text { wrapped and } \\
\text { front post at } \\
\text { bottom }\end{array}$ & $\begin{array}{l}\text { Intent is for the } \\
\text { individual to sit } \\
\text { in the chair } \\
\text { while vehicle is } \\
\text { moving }\end{array}$ & $\begin{array}{l}\text { video shows } \\
\text { them securing } \\
\text { wheelchair-not } \\
\text { scooter }\end{array}$ & $\begin{array}{l}\text { Permanently } \\
\text { attached, no } \\
\text { loose belts }\end{array}$ \\
\hline $\begin{array}{l}\text { Beam's } \\
\text { Industries } \\
\text { Inc. }\end{array}$ & $\begin{array}{l}\text { Customized } \\
\text { Tie-downs }\end{array}$ & $\begin{array}{l}\text { Depends on } \\
\text { uses and } \\
\text { conditions }\end{array}$ & Not answered & $\begin{array}{l}\text { All (see } \\
\text { scooter } \\
\text { note) }\end{array}$ & $\begin{array}{l}\text { Not } \\
\text { recommended }\end{array}$ & $\begin{array}{l}\text { Not } \\
\text { recommended }\end{array}$ & $\begin{array}{l}\text { No testing } \\
\text { related to } \\
\text { scooters has } \\
\text { been } \\
\text { conducted. }\end{array}$ & No & \\
\hline
\end{tabular}




\begin{tabular}{|c|c|c|c|c|c|c|c|c|c|}
\hline Vendor & Series & $\begin{array}{l}\text { Average } \\
\text { Service } \\
\text { Span of } \\
\text { System }\end{array}$ & $\begin{array}{l}\text { Recommended } \\
\text { position for } \\
\text { securing } \\
\text { mobility devices }\end{array}$ & $\begin{array}{c}\text { Compatible } \\
\text { mobility aid } \\
\text { devices }\end{array}$ & $\begin{array}{l}\text { Is this system } \\
\text { recommended } \\
\text { for use with } \\
\text { scooters? }\end{array}$ & $\begin{array}{l}\text { How is the } \\
\text { scooter } \\
\text { secured? }\end{array}$ & $\begin{array}{c}\text { Can / Should a } \\
\text { scooter be } \\
\text { used as a seat } \\
\text { in a moving } \\
\text { vehicle? }\end{array}$ & $\begin{array}{l}\text { Do you inform } \\
\text { customers (l.e. } \\
\text { transit agency, } \\
\text { etc.) about } \\
\text { incompatibility } \\
\text { of scooters? }\end{array}$ & $\begin{array}{l}\text { Comments } \\
\text { on Features }\end{array}$ \\
\hline $\begin{array}{l}\text { Beam's } \\
\text { Industries } \\
\text { Inc. } \\
\end{array}$ & $\begin{array}{l}\text { Customized } \\
\text { Tie-downs }\end{array}$ & $\begin{array}{l}\text { Depends on } \\
\text { uses and } \\
\text { conditions } \\
\end{array}$ & Not answered & $\begin{array}{l}\text { All (see } \\
\text { scooter } \\
\text { note) }\end{array}$ & $\begin{array}{l}\text { Not } \\
\text { recommended }\end{array}$ & $\begin{array}{l}\text { Not } \\
\text { recommended }\end{array}$ & $\begin{array}{l}\text { No testing } \\
\text { related to } \\
\text { scooters has } \\
\text { been } \\
\text { conducted. }\end{array}$ & No & \\
\hline $\begin{array}{l}\text { Ortho Safe } \\
\text { Systems }\end{array}$ & $\begin{array}{l}\text { Quick } \\
\text { Connect } \\
\text { Retractor } \\
\text { Series 2001 }\end{array}$ & $\begin{array}{l}\text { One year } \\
\text { under } \\
\text { normal wear } \\
\text { and tear } \\
\text { (lifetime } \\
\text { limited } \\
\text { warranty on } \\
\text { retractor) } \\
\end{array}$ & Forward-facing & $\begin{array}{l}\text { ADA } \\
\text { definition of } \\
\text { common } \\
\text { wheelchair } \\
\end{array}$ & $\begin{array}{l}\text { Only if scooter is } \\
\text { built to withstand } \\
\text { crash test }\end{array}$ & $\begin{array}{l}\text { No } \\
\text { recommended } \\
\text { approach - } \\
\text { depends on } \\
\text { scooter / May } \\
\text { need } \\
\text { additional } \\
\text { straps }\end{array}$ & $\begin{array}{l}\text { Not } \\
\text { recommended }\end{array}$ & $\begin{array}{l}\text { Communicate to } \\
\text { bus } \\
\text { manufacturers } \\
\text { and customers }\end{array}$ & $\begin{array}{l}\text { Must go } \\
\text { through bus } \\
\text { manufacturer }\end{array}$ \\
\hline $\begin{array}{l}\text { Ortho Safe } \\
\text { Systems }\end{array}$ & Series 1 & \begin{tabular}{|l|} 
One year \\
under \\
normal wear \\
and tear \\
(lifetime \\
limited \\
warranty on \\
retractor) \\
\end{tabular} & Forward-facing & $\begin{array}{l}\text { ADA } \\
\text { definition of } \\
\text { common } \\
\text { wheelchair } \\
\end{array}$ & $\begin{array}{l}\text { Only if scooter is } \\
\text { built to withstand } \\
\text { crash test }\end{array}$ & $\begin{array}{l}\text { No } \\
\text { recommended } \\
\text { approach - } \\
\text { depends on } \\
\text { scooter / May } \\
\text { need } \\
\text { additional } \\
\text { straps } \\
\end{array}$ & $\begin{array}{l}\text { Not } \\
\text { recommended }\end{array}$ & $\begin{array}{l}\text { Communicate to } \\
\text { bus } \\
\text { manufacturers } \\
\text { and customers }\end{array}$ & $\begin{array}{l}\text { Must go } \\
\text { through bus } \\
\text { manufacturer }\end{array}$ \\
\hline $\begin{array}{l}\text { Ortho Safe } \\
\text { Systems }\end{array}$ & Series 2 & \begin{tabular}{|l|} 
One year \\
under \\
normal wear \\
and tear \\
(lifetime \\
limited \\
warranty on \\
retractor)
\end{tabular} & Forward-facing & $\begin{array}{l}\text { ADA } \\
\text { definition of } \\
\text { common } \\
\text { wheelchair }\end{array}$ & $\begin{array}{l}\text { Only if scooter is } \\
\text { built to withstand } \\
\text { crash test }\end{array}$ & $\begin{array}{l}\text { No } \\
\text { recommended } \\
\text { approach - } \\
\text { depends on } \\
\text { scooter / May } \\
\text { need } \\
\text { additional } \\
\text { straps }\end{array}$ & $\begin{array}{l}\text { Not } \\
\text { recommended }\end{array}$ & $\begin{array}{l}\text { Communicate to } \\
\text { bus } \\
\text { manufacturers } \\
\text { and customers }\end{array}$ & $\begin{array}{l}\text { Must go } \\
\text { through bus } \\
\text { manufacturer }\end{array}$ \\
\hline
\end{tabular}




\begin{tabular}{|c|c|c|c|c|c|c|c|c|c|}
\hline Vendor & Series & $\begin{array}{l}\text { Average } \\
\text { Service } \\
\text { Span of } \\
\text { System }\end{array}$ & $\begin{array}{l}\text { Recommended } \\
\text { position for } \\
\text { securing } \\
\text { mobility devices }\end{array}$ & $\begin{array}{c}\text { Compatible } \\
\text { mobility aid } \\
\text { devices }\end{array}$ & $\begin{array}{l}\text { Is this system } \\
\text { recommended } \\
\text { for use with } \\
\text { scooters? }\end{array}$ & $\begin{array}{l}\text { How is the } \\
\text { scooter } \\
\text { secured? }\end{array}$ & $\begin{array}{c}\text { Can / Should a } \\
\text { scooter be } \\
\text { used as a seat } \\
\text { in a moving } \\
\text { vehicle? }\end{array}$ & $\begin{array}{l}\text { Do you inform } \\
\text { customers (I.e. } \\
\text { transit agency, } \\
\text { etc.) about } \\
\text { incompatibility } \\
\text { of scooters? }\end{array}$ & $\begin{array}{l}\text { Comments } \\
\text { on Features }\end{array}$ \\
\hline $\begin{array}{l}\text { Ortho Safe } \\
\text { Systems }\end{array}$ & Series 3 & $\begin{array}{l}\text { One year } \\
\text { under } \\
\text { normal wear } \\
\text { and tear } \\
\text { (lifetime } \\
\text { limited } \\
\text { warranty on } \\
\text { retractor) }\end{array}$ & Forward-facing & $\begin{array}{l}\text { ADA } \\
\text { definition of } \\
\text { common } \\
\text { wheelchair }\end{array}$ & $\begin{array}{l}\text { Only if scooter is } \\
\text { built to withstand } \\
\text { crash test }\end{array}$ & $\begin{array}{l}\text { No } \\
\text { recommended } \\
\text { approach - } \\
\text { depends on } \\
\text { scooter / May } \\
\text { need } \\
\text { additional } \\
\text { straps }\end{array}$ & $\begin{array}{l}\text { Not } \\
\text { recommended }\end{array}$ & $\begin{array}{l}\text { Communicate to } \\
\text { bus } \\
\text { manufacturers } \\
\text { and customers }\end{array}$ & $\begin{array}{l}\text { Must go } \\
\text { through bus } \\
\text { manufacturer }\end{array}$ \\
\hline $\begin{array}{l}\text { Ortho Safe } \\
\text { Systems }\end{array}$ & Series 4 & $\begin{array}{l}\text { One year } \\
\text { under } \\
\text { normal wear } \\
\text { and tear } \\
\text { (lifetime } \\
\text { limited } \\
\text { warranty on } \\
\text { retractor) } \\
\end{array}$ & Forward-facing & \begin{tabular}{|l|} 
ADA \\
definition of \\
common \\
wheelchair \\
\end{tabular} & $\begin{array}{l}\text { Only if scooter is } \\
\text { built to withstand } \\
\text { crash test }\end{array}$ & $\begin{array}{l}\text { No } \\
\text { recommended } \\
\text { approach - } \\
\text { depends on } \\
\text { scooter / May } \\
\text { need } \\
\text { additional } \\
\text { straps }\end{array}$ & $\begin{array}{l}\text { Not } \\
\text { recommended } \\
\end{array}$ & $\begin{array}{l}\text { Communicate to } \\
\text { bus } \\
\text { manufacturers } \\
\text { and customers } \\
\end{array}$ & $\begin{array}{l}\text { Must go } \\
\text { through bus } \\
\text { manufacturer }\end{array}$ \\
\hline Latchlok & $\begin{array}{l}\text { Automatic } \\
\text { Power } \\
\text { Wheelchair } \\
\text { Tie-Down } \\
\end{array}$ & $\begin{array}{l}\text { Depends, } \\
\text { replace } \\
\text { parts }\end{array}$ & Forward-facing & $\begin{array}{l}\text { Power and } \\
\text { Manual }\end{array}$ & $\begin{array}{l}\text { Not } \\
\text { recommended }\end{array}$ & $\begin{array}{l}\text { Not } \\
\text { recommended }\end{array}$ & $\begin{array}{l}\text { Not } \\
\text { recommended }\end{array}$ & $\begin{array}{l}\text { Won't put devices } \\
\text { on scooters }\end{array}$ & $\begin{array}{l}\text { Latching or } \\
\text { docking } \\
\text { mechanism } \\
\text { required on } \\
\text { chair }\end{array}$ \\
\hline
\end{tabular}




\section{Section Three: \\ Discussion}

It is clear that, while the requirements outlined in the ADA transportation regulations related to the installation, upkeep, and use of wheelchair securement equipment in public transportation vehicles were, in part, designed to ensure that persons using mobility aid devices are afforded full accessibility to transit services, several factors appear to be contributing to incomplete fulfillment of this goal. The findings of the Securement Device Options and Strategies Survey and the Wheelchair Securement Device Inventory confirm and emphasize that policy, passenger, transit provider, operator, and industry issues continue to exist and will only be resolved through aggressive action. The most common themes that have been noted herein are related to misinterpretation and/or lack of understanding of the ADA wheelchair securement regulations and policies, the pressing need to accommodate a growing variety of "common" and "non-common" mobility devices, as well as issues related to the development and implementation of standards for mobility devices that will be used by passengers on public transportation vehicles. In addition, the survey results illustrate the range of strategies that are being employed by transportation providers to address some of these issues and overcome securement challenges so that passengers who use mobility devices are afforded the maximum mobility options possible. It is heartening to see that the spirit of the Americans with Disabilities Act of 1990 is, for the most part, guiding the actions and policies of public transportation providers.

However, the survey results also raise a number of important questions that still require resolution, such as: Is the number of passengers with disabilities who are being denied transportation service increasing? And, is the safety of public transportation passengers and operators being jeopardized by inadequate wheelchair securement of oversized or difficult to secure mobility devices? If yes, this emerging reality strongly suggests that agencies will need to make additional accommodations within their fleets in the very near future to support the growing number of mobility aid devices in use with frames that are difficult to secure or with dimensions that exceed the ADA standard for common wheelchairs. However, as the survey findings illustrate, even some agencies that are considered 100 percent accessible to persons with disabilities by ADA standards are unable to accommodate many commonly used mobility aid devices. Scooters, in particular, present tremendous challenges to the securement process 
and are generally not considered safe for use as passenger seats on moving transit vehicles by many of the survey respondents. How then should agencies respond to the growing use of 3and 4-wheel scooters on their vehicles? Because these mobility devices typically meet the dimensions of a "common wheelchair," public transportation providers are required to accommodate them, despite the fact that these mobility devices often cannot be adequately secured with ADA-compliant securement equipment. As the Wheelchair Securement Device Inventory shows, few securement options currently exist that specifically address the challenges presented by 3- and 4-wheel scooters. In fact, even the companies that offer specialized equipment to address scooter securement concerns do not recommend that scooters secured with their equipment be used as a seat on a moving public transportation vehicle (see Table 30). This raises important questions regarding whether and how the FTA should reevaluate the official position on mobility device securement given the difference in the dynamics of scooters and other types of "common wheelchairs."

Of further consideration is how agencies might resolve the potential conflict presented by agency policy that seeks to accommodate every passenger using a mobility device, and passengers who use mobility devices that far exceed "common wheelchair" dimensions. Several survey respondents expressed the opinion that these and other issues will continue to challenge the industry until mobility device manufacturers are required to address some of the more common accommodation issues. Specific suggestions provided include outfitting mobility devices intended for use on transit vehicles with connectors that would allow standard securement devices to be effective; requiring manufacturers to identify the best securement points on mobility devices; and requiring manufacturers and distributors to identify those devices that should not be used as a seat on a transit vehicle.

The findings of the Securement Device Options and Strategies Survey and the Wheelchair Securement Device Inventory provide strong support for the need for a proactive and progressive approach for resolving the ongoing and serious issues related to wheelchair securement on public transportation vehicles that have been discussed throughout this report. As a result of the implications of the survey and inventory findings presented herein, two recommendations are offered to assist in the resolution of the existing disjuncture related to 
ADA wheelchair securement requirements and difficulties encountered in the securement of common and non-common wheelchairs on public transportation vehicles.

\section{Recommendation 1: Seek FTA Clarification related to I nconsistent Securement Definitions \& Policies}

Currently, the ADA transportation regulations established by the USDOT and administered by the FTA provide definition and direction as regards all facets of public transportation provision to people with disabilities, including issues related to mobility devices and wheelchair securement. The ADA transportation regulations delineate the dimensions of a "common wheelchair" and clearly state that passengers with disabilities who use common wheelchairs must be provided transportation either on fully accessible fixed-route service or complementary paratransit service. Additionally, the ADA regulations require that ADA-compliant wheelchair securement locations and equipment be included on public transportation vehicles. Detailed specifications are also provided to ensure that the wheelchair securement locations and equipment are ADA-compliant. However, a disjuncture currently exists between some mobility devices that are considered "common wheelchairs" and ADA-compliant securement equipment. Specifically, public transportation providers consistently report difficulties associated with securing 3- and 4-wheel scooters with ADA-compliant wheelchair securement equipment, despite the fact that most of these mobility devices have dimensions that fall within those outlined for common wheelchairs. This presents a significant dilemma for public transportation providers. Because these devices fit the definition of a common wheelchair, they must be accommodated on public transportation vehicles. However, many of these mobility devices lack traditional securement points and are difficult to secure with ADA-compliant wheelchair securement equipment. Therefore, public transportation providers are challenged to secure these "common wheelchairs" as best they can, even if the safety of passengers and vehicle operators is jeopardized. The Securement Device Options and Strategies Survey has demonstrated that the majority of securement-related injuries on public transportation vehicles are the result of inadequate securement or unstable mobility devices, with scooters consistently identified as problematic on both counts. Therefore, it is recommended that the FTA address the existing disconnect between the definition of a "common wheelchair" and the definition of ADA-compliant securement equipment in order to ensure the safety of all public transportation passengers and vehicle operators. 


\section{Recommendation 2: Make ANSI/ RESNA Standard WC/ Volume 1 - Section 19 Wheelchairs - Wheelchairs Used as Seats in Motor Vehicles Mandatory for Public Transportation}

This recommendation specifically aims to address existing securement challenges that stem from either the lack of securement points on some types of mobility devices or the use of mobility devices that are not sturdy enough to withstand proper securement without resulting in damage. This report has already documented many securement-related problems that public transportation providers are experiencing with mobility devices, such as 3- and 4-wheel scooters, that are difficult to secure with ADA-compliant wheelchair securement equipment. In addition, the Wheelchair Securement Device Inventory discussed in Section Two of this report revealed that all identified securement equipment vendors/manufacturers recommend that passengers who use 3- and 4-wheel scooters be asked to transfer to a vehicle seat, rather than using their mobility device as a seat on a moving vehicle. This recommendation is the direct result of difficulties associated with securing this type of mobility device and the potential for passenger injury. However, requesting that passengers transfer to a vehicle seat does not fully resolve this problem, as many passengers who use mobility devices may not be able to transfer and those who are able cannot be required to transfer to a vehicle seat, per the ADA transportation regulations. In addition, many transit vehicles do not have passenger restraint belts available. Therefore, it would not be feasible or reasonable to transfer passengers who have disabilities that make it difficult or impossible to support themselves to vehicle seats during transport. In an effort to resolve the significant challenges presented by the need to safely and effectively secure a wide variety of mobility devices and the desire by many passengers to use these devices as seats on moving vehicles, the American National Standards Institute (ANSI) and the Rehabilitation Engineering and Assistive Technology Society of North American (RESNA) have developed a voluntary standard (ANSI/RESNA Standard WC/Volume 1 - Section 19 Wheelchairs - Wheelchairs Used as Seats in Motor Vehicles) that specifies general design requirements, test procedures, and performance requirements wheelchairs that are designed for use as a forward-facing seat in a motor vehicle.

The intent of the ANSI/RESNA standard, WC/Volume 1 - Section 19 Wheelchairs - Wheelchairs Used as Seats in Motor Vehicles (hereafter referred to as ANSI/RESNA WC/Vol. 1 - Section 19), 
is to improve occupant safety and reduce the risk of injury when passengers remain seated in their mobility device during transport. This is accomplished by improving the crashworthiness of mobility devices that conform to the design specifications outlined in the standard. Mobility devices that are manufactured to comply with the standard will have additional features that provide increased levels of occupant security and safety while riding in a motor vehicle. The standard seeks to resolve the disconnect that sometimes exists between the compatibility of wheelchair securement systems and the provisions for securement provided on mobility devices. Because 4-point tie-down/belt systems are the most common and effective method for securing a wide variety of wheelchair types and sizes, ANSI/RESNA WC/Vol. 1 - Section 19 requires that mobility devices be designed and tested for effective securement by a 4-point tiedown/belt system. This standard also addresses the challenge of locating securement points on mobility devices by specifying both the number and location of securement points on mobility devices that will be used as seats on moving vehicles. This ensures that safe and effective securement will be possible for all mobility devices that meet the ANSI/RESNA WC/Vol. 1 Section 19 standard.

The ANSI/RESNA WC/Vol. 1 - Section 19 standard was adopted as a U.S. national standard on April 19, 2000. However, compliance with this standard currently is voluntary. This means that transportation service cannot be denied to passengers who use mobility devices that do not comply with the standard. It is recommended that compliance with ANSI/RESNA WC/Vol. 1 Section 19 Wheelchairs - Wheelchairs Used as Seats in Motor Vehicles be made mandatory for all mobility devices that are intended for use by public transportation passengers. It is also recommended that mobility device manufacturers be required to certify that their products meet the ANSI/RESNA WC/Vol. 1 - Section 19 standard. Mobility device manufacturers and vendors should also be required to inform potential purchasers about mobility devices that cannot be safely secured on transit vehicles. Such actions will ensure that public transportation providers are able to effectively secure the mobility devices used by passengers and that the safety of passengers and operators is maximized.

Although the findings of the Securement Device Options and Strategies Survey reveal that many specific securement challenges exist for which there are no easy answers, it is clear that most public transportation providers are embracing the intent of the ADA - equal access to available 
mobility opportunities for all people. With this goal as a guiding force, there are few challenges that cannot be overcome through the continued dogged dedication and creative thinking that was clearly expressed by survey participants. However, implementation of the recommendations identified above will facilitate full and complete compliance with all aspects of the ADA transportation regulations by making all relevant parties (i.e., policy makers, transportation providers, operators, passengers, wheelchair manufacturers, and securement equipment manufacturers) full and equal participants in efforts to achieve the goal of full access to safe public transportation services. 


\section{Appendix A}

\section{Securement Device Options \& Strategies Survey}




\section{Mobility Aid SeCURement DeVice Options AND Strategies SuRVey}

\section{General Contact Information - Please make corrections in the space provided below.}

Contact name:

Name of organization:

Address:

City: State: Zip Code:

Phone: Fax:

E-mail:

\section{Please tell us about your agency...}

1. What types of transportation service(s) does your agency provide? (Please $U$ all that apply.)

، 1 Fixed schedule, fixed route

${ }^{\prime}{ }_{2}$ Curb-to-curb service
، 3 Door-to-door service

${ }_{4}$ Other (please specify)

2. How many vehicle operators does your agency employ? (Please $U$ all that apply.)

‘ 1 Full-time drivers

‘ 2 Part-time drivers

3. How many vehicles do you have in your fleet? vehicles

4. How many of your vehicles are accessible to people with disabilities?

${ }_{1}$ Vehicles less than 22 feet in length

${ }{ }_{2}$ Vehicles greater than 22 feet in length

\section{Accommodation of Mobility Devices}

5. Please rank the following mobility aid devices according to those most often used by your passengers ( 1 - used most often, 5 - used least often)

-1 Manual Wheelchair

Powered Wheelchair

4-wheel Scooter

3-wheel Scooter

6. Do any of your passengers use mobility aid devices that do not fit the definition of "common wheelchair," as specified in the ADA of 1990 ? (The ADA of 1990 defines a common wheelchair as a mobility device that is no larger than 30 inches in width, 48 inches in height, and weighs no more than 600 pounds when occupied.)

$، 1$ Yes

${ }_{2}$ No

7. Are you able to secure mobility aid devices that do not fit the definition of "common wheelchair" with an ADA-compliant securement system on your vehicles?

$‘$ Yes, on all vehicles

‘ 2 No, not on any vehicles

${ }_{3}$ Only on some vehicles

\section{Mobility Aid Device Policies}

8. Does your agency have a policy that requires the securement of mobility aid devices?
$،$ Yes
${ }_{2}$ No
‘ 3 Don't know

9. If yes, is the policy stated in a manual, handbook, or other printed document?
$،$ Yes
‘2 No
‘ 3 Don't know

10. Does your agency have a formal policy related to the securement of mobility aids that do not meet the definition of "common wheelchair"? 


\section{Mobility Aid Securement Device Options and Strategies SuRvey}

11. Please briefly describe your agency's policy regarding the accommodation of mobility aid devices that do not meet the definition of "common wheelchair."

12. For what reasons have your operators denied a trip to a passenger in a mobility aid device? (Please $U$ all that apply)

‘ 1 Not applicable

' 2 Mobility aid device too big

‘ 3 Passenger refused to be secured

${ }_{4}$ Unable to secure device with securement system
${ }_{5}$ Unfamiliar with securement equipment

‘6 Unfamiliar with mobility aid device

1 Securement equipment broken

${ }_{8}$ Other (please explain)

13. What complaints have you received from riders regarding securement? (Please $U$ all that apply)?

$،$ Do not want to be secured

' 2 Do not want to be assisted by driver

، 3 Securement equipment damages mobility aid device

${ }_{4}$ Do not feel safe
' ${ }_{5}$ Securement equipment does not work properly

‘ 6 Driver does not know how to use securement equipment properly

$\checkmark$ Do not like position of mobility device while riding (front, rear, angled)

${ }_{8}$ Other (please explain)

14. What complaints have you received from operators regarding the securement of mobility aid devices? (Please $U$ all that apply)?

$،$ Passengers do not want to be secured

' 2 Securement takes too much time

${ }_{3}$ Securement is too difficult

${ }_{4}$ Other (please explain)
${ }{ }_{5}$ Do not want to assist passengers with securement

، 6 Do not know how to use securement equipment

' 7 Securement equipment does not work properly

15. Which of the following statements best describes how your drivers most often respond to passengers with mobility aid devices that do not fit the definition of "common wheelchair" (A mobility device that is no larger than 30 inches in width, 48 inches in height, and weighs no more than 600 pounds when occupied)? (Please U only one)

‘ 1 Deny the trip

$، 2$ Request a different vehicle from dispatcher

4 Allow boarding and secure device to best ability

${ }_{3}$ Other (please explain)

16. Please describe any strategies that your agency has developed to accommodate mobility aid devices that do not fit the definition of a "common wheelchair."

\section{Type(s) of Securement System}

17. Do you have standard securement equipment for all vehicles, or does the equipment vary by vehicle?

' 1 Standard securement equipment for all vehicles ' ${ }_{2}$ Securement equipment varies by vehicle

18. What type(s) of securement systems does your agency utilize? (Please U all that apply)

‘ 1 Wheel lock device

‘ 2 Tie-down/belt system

${ }_{3}$ Docking/interface system
‘ 4 T-bar

5 Fender brackets

' ${ }_{6}$ Other (please specify)

19. Which of the above is used most often?

20. What are the advantages of the system utilized most often (identified in question 18)? 


\section{Mobility Aid Securement Device Options and Strategies SuRvey}

21. What are the disadvantages of the system utilized most often (identified in question 18)?

22. Which, if any, of the securement systems listed below are you unfamiliar with? (Please U all that apply)

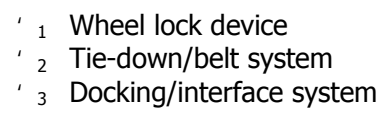

${ }_{4}$ T-bar

${ }_{5}$ Fender brackets

${ }_{6}$ Other (please specify)

23. Does your agency's governing body or other entity have securement system requirements beyond those included in the Americans with Disabilities Act of 1990 (ADA)?

‘ 1 Yes

${ }_{2}$ No

24. When selecting the type(s) of securement device for your agency's vehicle, which of the following criteria did you use? (Please $U$ all that apply)

' 1 Cost to install and maintain

، 2 Standard equipment included with vehicle purchase

' 3 Most common device available

' 4 Cost of equipment

' 5 Time required to secure mobility aid devices

' 6 Vendor recommendation

$\checkmark$ Structural integrity of securement device

' 8 Believe is the safest product

‘ Reputation of the product

$\checkmark{ }_{10}$ Ease of installation

' ${ }_{11}$ Ease of operator training

' ${ }_{12}$ Ability to be used with many types of mobility aid devices

' 13 Ease of use

' ${ }_{14}$ Quick emergency evacuation

‘ 15 Less impact on vehicle passenger capacity

${ }_{16}$ Other (please explain)

25. Which one of the criteria listed in question $\mathbf{2 4}$ had the greatest impact on your decision to purchase the selected securement device?

26. Have there been any driver/attendant or passenger injuries associated with your vehicles' securement equipment or procedures in the past three years?
${ }_{1}$ Yes
${ }_{2}$ No

If yes, please describe:

27. On average, how much time is required to secure mobility aid devices using the securement system(s) on your agency's vehicles?

$، 1$ One minute or less

' 2 Between 1 and 3 minutes
، 3 to 5 minutes

${ }_{4}$ More than 5 minutes

\section{Maintenance of Securement Systems}

28. How is securement equipment usually installed in agency vehicles? (Please $\mathrm{U}$ only one)

‘ Installed by maintenance team

‘ 2 Factory-installed with vehicle purchase
‘ 3 Installed by outside agency/individual

${ }_{4}$ Other

29. What type of training related to the installation and maintenance of securement equipment does your agency's maintenance team receive? (Please $U$ all that apply)

1 Vendor training

$، 2$ Training course

${ }_{3}$ Other (please specify)

$\checkmark 4$ Video training

${ }_{5}$ No training is provided

30. Which most often occurs if a vehicle has malfunctioning securement equipment?

' 1 The vehicle is immediately taken out of service until repair is completed

' 2 The vehicle remains in service until repair is scheduled; mobility aid devices are not secured

' 3 The vehicle remains in service until repair is scheduled but does not transport passengers using mobility aid devices

${ }_{4}$ Other (Please specify) 


\title{
Mobility Aid SeCURement Device Options AND Strategies SuRVey
}

31. Which of the following maintenance problems has your agency experienced in relation to the securement system(s) that are installed in your vehicles? (Please $U$ all that apply)

‘ 1 Repairs are costly

‘ 2 Repairs are difficult

${ }_{3}$ Other (please specify)

${ }_{4}$ Equipment wears easily

${ }_{5}$ Staff is not properly trained to maintain the equipment

\section{Operator Training}

32. Do all operators receive training on use of securement systems?
${ }_{1}$ Yes
${ }_{2}$ No
‘ 3 Don't know

33. What type of training on the use of securement system is provided to operators? (Please $U$ all that apply)

$، 1$ Training course

2 Peer-to-peer training

3 No training is provided
${ }_{4}$ Video course

${ }^{4}$ Vendor training

${ }_{6}{ }_{6}$ Other (please specify)

34. Did the vehicle manufacturer or securement system vendor offer training for your operators?
$،$ Yes
' 2 No
‘ 3 Not Applicable

\section{Thank you!}

Please return the completed survey in the enclosed self-addressed stamped envelope by May 21, 2001.

\author{
Return to: \\ Chandra Foreman \\ Center for Urban Transportation Research (CUTR) \\ University of South Florida (USF) \\ 4202 E. Fowler Avenue, CUT 100 \\ Tampa, FL 33620-5375
}

You may also Fax the completed survey to (813) 974-5168

Attention: Chandra Foreman

Should you have any questions or comments regarding this survey, please contact Chandra Foreman or Jennifer Hardin, Center for Urban Transportation Research (CUTR), at (813) 974-3120 or by email at foreman@cutr.eng.usf.edu or hardin@cutr.eng.usf.edu 


\section{Appendix B}

\section{Wheelchair Securement Device I nventory Questionnaire}




\section{CENTER FOR URBAN TRANSPORTATION RESEARCH QUESTIONNAIRE: SECUREMENT DEVICES}

Vendor:

Survey Completed by:

What are the series your company manufactures or sell?

List the Model Number(s) under each Series

Is the device type a 2 or 4-point tie-down, wheel lock, docking/interface, or other type of system?

Do the products meet:

SAE J2249 requirements

ISO 10542 requirements

$30 \mathrm{mph} / 20 \mathrm{G}$ Impact Tests

List the vehicle specifications required (like FMVSS 209, 222, 210, 302):

For Belt or Tie Down Systems:

Are the Belts Retractable or Adjustable?

Is Mounting Hardware included?

How many belts are there?

What types of mobility aid devices are compatible?

Regular wheelchairs

Electric wheelchairs

Tri-wheelers

Scooters

Are scooters (or tri-wheelers) recommended for use with your system? Please explain

If scooters are recommended (or allowed), how are they secured with your system? Please explain

If scooters are recommended (or allowed), do you recommend the passenger stay seated in scooter, or transfer to another seat while the vehicle is moving? Please explain

If scooters are not recommended (or allowed), how are customers/dealers informed of the problem with scooters? Please explain 


\title{
CENTER FOR URBAN TRANSPORTATION RESEARCH QUESTIONNAIRE: \\ SECUREMENT DEVICES
}

What is the device cost or range of costs?

What is included in cost?

Are any training material (manuals, videos) included in the cost, please describe?

Will a salesman be available to help with installation or train on the uses of the product if requested, is it free or at cost? Please describe

Identify any FL agencies that use your device

What is the life or recommended service span of system

What is the recommended position for securing this device?

Rear-facing

Forward-Facing

Please return your responses to:

\author{
Stephanie Eckert \\ Center For Urban Transportation Research \\ University of South Florida \\ 4202 East Fowler Avenue, CUT 100 \\ Tampa, FL 33620 \\ Tel: 813-974-9768 \\ Fax: 813-974-5168 \\ eckert@cutr.eng.usf.edu
}

If you have any questions concerning this questionnaire, please feel free to call or email Stephanie at the above number. You may also contact Jennifer Hardin, the Research Associate for this project, at (813) 974-1092. Thank you for your help in this matter. 
